RENATO VIZIOLI

\title{
Subsídios para Utilização da Base de Dados Corporativa na Atividade de Projetos
}

\author{
Dissertação apresentada à Escola \\ Politécnica da Universidade de São Paulo \\ para obtenção do título de Mestre em \\ Engenharia. \\ Área de Concentração: Engenharia Mecânica \\ Orientador: Professor Doutor Paulo Carlos \\ Kaminski
}

São Paulo

2000 


\section{Sumário}

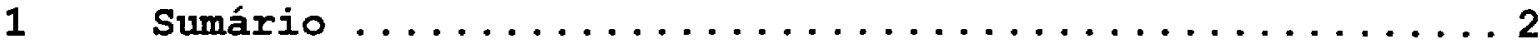

2 Lista de Figuras .....................

3 Lista de Tabelas ......................

4 Lista de Terminologias e Abreviaturas ............9

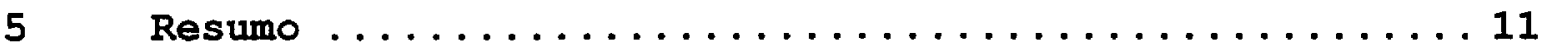

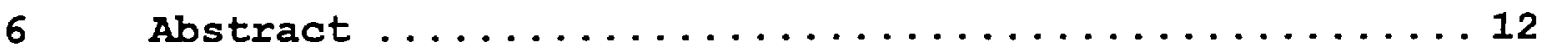

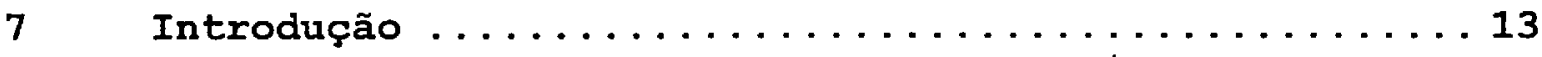

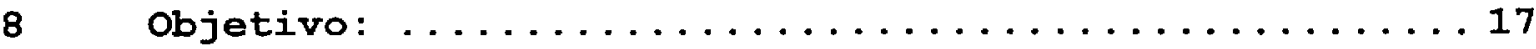

9 Definições Gerais ...................... 20

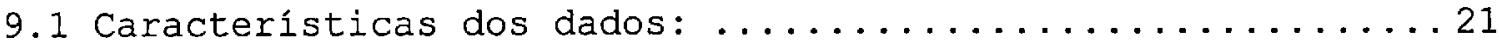

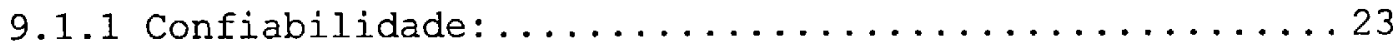

9.1 .2 Acessibilidade $\ldots \ldots \ldots \ldots \ldots \ldots \ldots \ldots \ldots \ldots \ldots \ldots$

9.1 .3 Durabilidade....................... 24

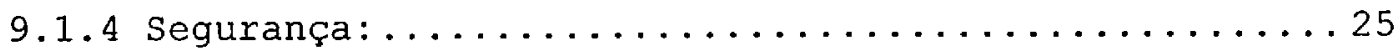

9.2 Caracterização de Informação $\ldots \ldots \ldots \ldots \ldots \ldots \ldots \ldots \ldots \ldots$

9.3 Caracterização de Operações ................... 27

9.4 Caracterização de Desenvolvimento de Produtos: ......... 31

9.5 "Workflow" - Fluxo de trabalho ou seqüência de tarefas: ... 32

10 Projeto Mecânico Assistido por Computador .........34

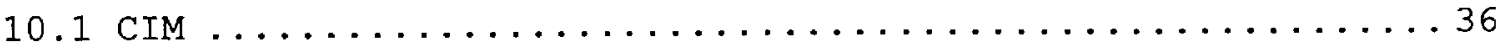

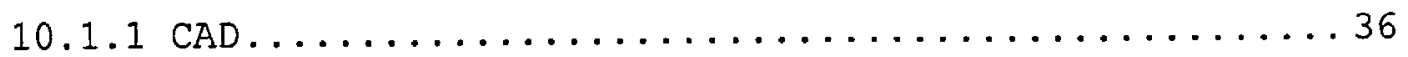

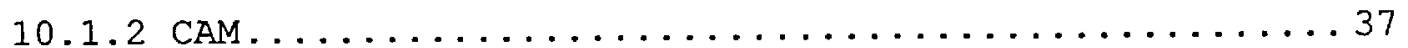

10.1 .3 o ciclo de produto e o CAD/CAM............... 38 
10.1.4 Automação e CAD/CAM....................... 38

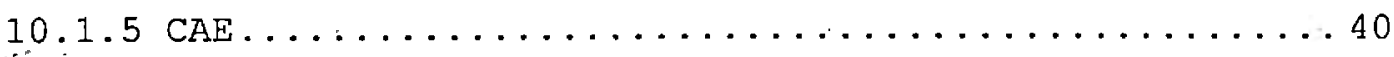

10.2 o Processo de Projetar e as Aplicações do Computador ....40

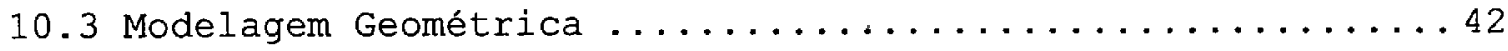

10.4 Análise de Engenharia $\ldots \ldots \ldots \ldots \ldots \ldots \ldots \ldots \ldots \ldots \ldots \ldots \ldots \ldots \ldots \ldots \ldots$

10.5 Revisão e Avaliação do Projeto ................. 44

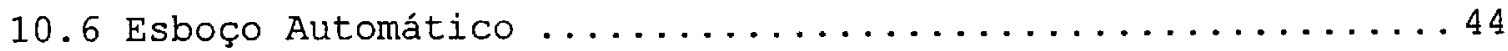

10.7 Base de Dados Associada ao Projeto ............... 44

10.8 Benefícios do uso do Projeto Auxiliado por Computador ... 46 10.8.1 Aumento de Produtividade no Projeto..........47 10.8.2 Tempos menores de Planejamento e Preparação do Produto............................. 47

10.8 .3 Análise do Projeto................. 47

10.8.4 Menor Quantidade de Erros de Projeto...........48

10.8.5 Maior Precisão nos Cálculos de Projeto.........48

10.8.6 Desenhos mais Compreensiveis.............. 48

10.8.7 Processos de Melhorias para Mudanças na Engenharia. 49

10.8.8 Benefícios na Manufatura............... 49

10.9 A Construção nos Softwares de Sistemas Gráficos ........ 50

10.10 Funções de um Pacote Gráfico .................. 51

10.10.1 Geração de Elementos Gráficos.............. 51

10.10 .2 Transformações...................... 51

10.10 .3 Funções de visualização............... 52

10.10 .4 Funções de segmentação................ 52

10.10 .5 Funções de entrada de dados.............. 52

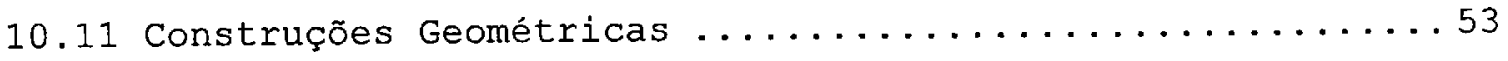


10.11 .1 o Uso de Elementos Gráficos............... 53

10.11.2 Definindo Elementos Gráficos............. 53

10.11 .3 Editando a Geometria................. 54

10.12 Transformações ............................ 55

10.13 Estrutura e Conteúdo da Base de Dados .............. 56

10.14 Estrutura em Arame (Wire-Frame) e Modelagem Sólida .....57

10.14.1 A Importância da Geometria Tridimensional....... 57

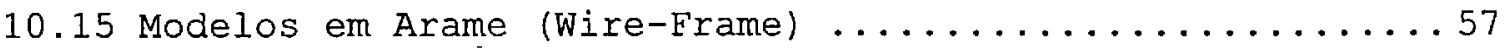

10.15.1 Modelos Sólidos.................... 58

10.16 Importação e Exportação de Desenhos ............... 59

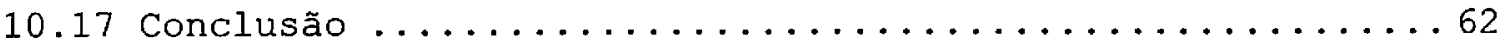

11 Dados e Informações dentro da Empresa . . . . . . . . 64

11.1 "Data warehousing" ....................... 64

11.2 Abordagem convencional dos dados. ..............6 64

11.3 Recuperação de dados de sistemas legados $\ldots \ldots \ldots \ldots \ldots \ldots 66$

11.4 DSS e EIS ("Decision-Support System" e "Executive Information systems") - Sistema de Suporte à decisão e Sistema de Informação Executiva . . . . . . . . . . . . . . . . . . 66

11.5 Requisitos do negócio $\ldots \ldots \ldots \ldots \ldots \ldots \ldots \ldots \ldots \ldots \ldots \ldots \ldots \ldots \ldots \ldots$

11.5.1 Integração dos dados da empresa:...........6 69

11.6 o funcionamento do data warehouse $\ldots \ldots \ldots \ldots \ldots \ldots \ldots 70$

12 Aspectos Gerais de Interfaceamento ............73

12.1 Análise do Universo de Dados Corporativos .............79

12.1.1 Análise da empresa como um todo..............79

12.1.2 Análise dos Fatores Críticos do Sucesso (FCSs) ....80

12.1.3 Método do "Balanced Scorecard" ............83 
13 Sistema de Informação para Projetos ............89

13.1 Particularização do Método "Balanced Scorecard" ........89

13.2 Fatores Específicos da Área de Projetos: ............992

13.3 Definição dos conteúdos de cada cartão do método "Balanced Scorecard" . ............................ 101

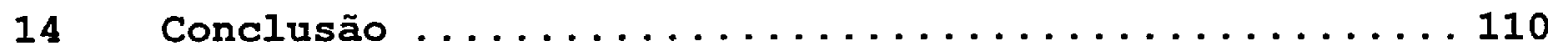

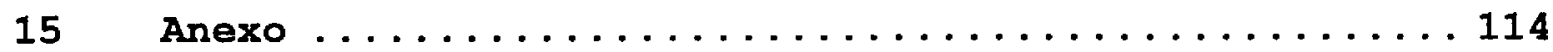

15.1 Exemplo de aplicação de Engenharia Simultânea . . . . . . 114 15.1.1 Projeto Paramétrico de Elementos de Máquinas..... 114 15.1.2 Engenharia Simultânea com Negociação Utilizando Diagramas de Projeto...................... 116

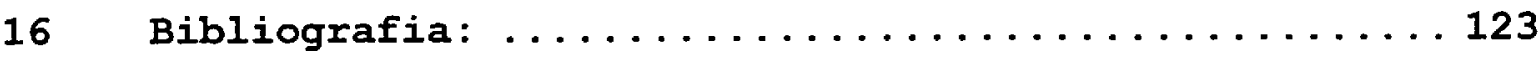




\section{Lista de Figuras}

Figura 1: Interface entre informações corporativas e atividade de projetar............................ 18

Figura 2: Variação da temperatura em uma estufa. ...........22

Figura 3: Algumas interfaces da função de operações com outras funções da empresa. (GIANESI; CORRÊA (1994)) . . . . . . . . . 29

Figura 4: Estruturação integrada de áreas em uma empresa segundo a

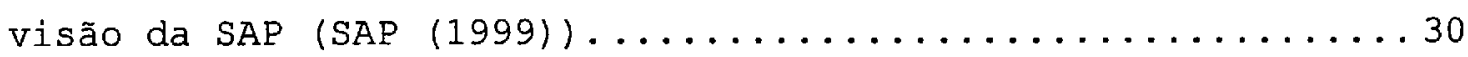

Figura 5: Projeto de ponte levadiça de Leonardo da Vinci (Fonte: Internet: http://www.museoscienza.org/english/leonardo) ......35

Figura 6: As várias etapas de um projeto (SHIGLEY (1989) adaptado) . . . . . . . . . . . . . . . . . . . 41

Figura 7: Relacionamento CAD/CAM através das bases de dados

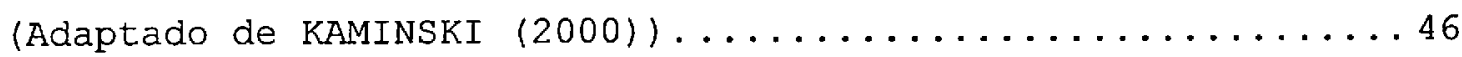

Figura 8: Facilidade de visualização de desenhos em CAD (GROOVER;

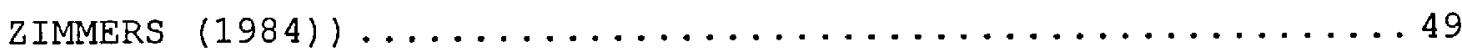

Figura 9: Objeto sem sentido físico (Notas de aulas) ........58

Figura 10: Conversão direta entre dois tipos de CAD ........60

Figura 11: Conversão com uso de padrão intermediário. . . . . . . 61

Figura 12: Impacto da revolução tecnológica (adaptado de GUPTA

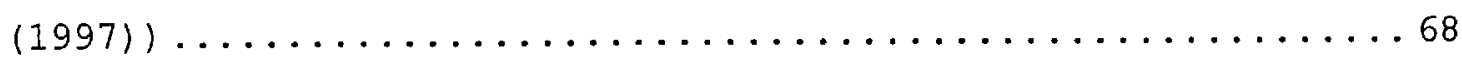

Figura 13: Critérios de formação de um "Data warehouse" (adaptado de GUPTA (1997)) .............................. 71

Figura 14: Fluxograma do método de análise dos FCSs. (LAUdoN;

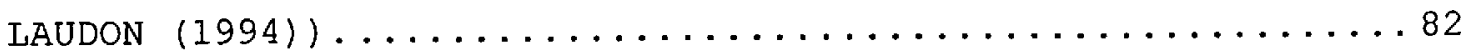
Figura 15: Definição de indicadores através de metas (KAPLAN;

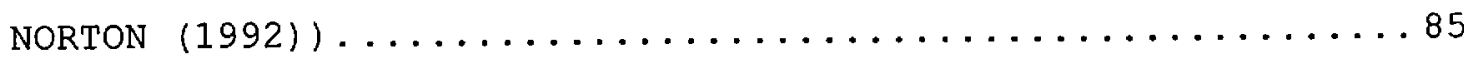
Figura 16: Diagrama de Henderson (KAPLAN; NORTON (1992)) .....87 
Figura 17: Algumas metas para a área de projetos (modificado de

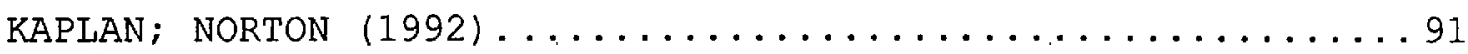

Figura 18: Fases de desenvolvimento de um projeto (ASIMOV (1962)).

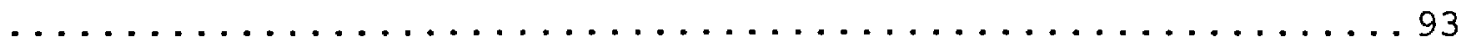

Figura 19: Síntese comparativa entre metodologias de Projeto

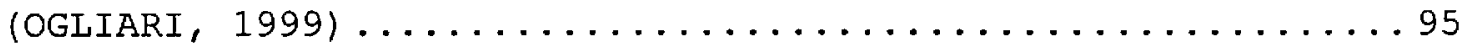

Figura 20: Válvula de controle de pressão.............. 117

Figura 21: Relacionamento entre parâmetros para cálculo da válvula.................................. 121 


\section{Lista de Tabelas}

Tabela 1: Caracterização de um dado. ..................... 21

Tabela 2: Tipo de automação em função do tipo de produção (GROOVER; ZIMMERS (1984)) ...................... 39

Tabela 3: Métodos de definição de elementos em computadores gráficos interativos (Fontes: Notas de aulas/Manuais de Softwares) . . . . . . . . . . . . . . . . . . . . 54

Tabela 4: Caracteristicas de edição mais comuns em CAD (Fontes: Notas de aulas/Manuais de Softwares) ................ 55

Tabela 5: Metas em função dos FCSs (ROCKART (1979)) . . . . . . . 83

Tabela 6: Exemplo de setores envolvidos e responsáveis pelas atividades de desenvolvimento de um produto............998

Tabela 7: Sistemas envolvidos nas atividades de cada área da empresa (levantamento de sistemas dentro da empresa na qual 0 autor atua) ................................ 100

Tabela 8: Análise do cartão da Perspectiva Financeira no método do "Balanced Scorecard" para o desenvolvimento de projeto de produto em uma empresa comercial................. 102

Tabela 9: Análise do cartão da Perspectiva do Consumidor no método do "Balanced Scorecard" para o desenvolvimento de projeto de produto em uma empresa comercial................. 104

Tabela 10: Análise do cartão da Perspectiva Interna do Negócio no método do "Balanced Scorecard" para o desenvolvimento de projeto de produto em uma empresa comercial............. 105

Tabela 11: Análise do cartão "Perspectiva da Inovação e do Aprendizado" do método "Balanced Scorecard" para desenvolvimento de projeto de produto.............. 107

Tabela 12: Passos para resolução do problema da barra........116 


\section{Iista de Terminologias e Abreviaturas}

Abap: código de programação/estruturação utilizado pelo software de gestão da SAP.

CAD: Projeto Auxiliado por Computador (do Inglês: "Computer Aided Design") .

CAE: Engenharia Auxiliada por Computador (do Inglês: "Computer Aided Engineering").

CAM: Manufatura Auxiliada por Computador (do Inglês: "Computer Aided Manufacturing").

CIM: Manufatura Integrada por Computador (do Inglês: "Computer Integrated Manufacturing").

CNC: Máquina que a partir de um conjunto de comandos numéricos elabora uma série de operações mecânicas.

DSS: Sistema de Suporte à Decisão (do Inglês: "Decision Support System").

EIS: Sistema de Informação ao Executivo (do Inglês: "Executive Information System").

FCS: Fatores Críticos do Sucesso -- terminologia utilizada no mapeamento de pontos prioritários a serem tratados em um dado projeto.

Handheld: Termo em inglês para designar os equipamentos portáteis de coleta de dados ou mesmo de processamento de dados, muitas vezes com características similares às de um micro computador. Lotus Notes: software da IBM para automação de "workflows". PCP: Planejamento e Controle da Produção.

R/3: Software de gestão criado pela SAP.

SAD: Sistema de Apoio à Decisão. 
SAP: Empresa alemã detentora do software de gestão "R/3". A sigla significa "Analista de Sistemas e Processos".

Sistemas Legados: Sistemas corporativos ou mesmo específicos de alguma área que não pertencem ao escôpo do sistema gerencial vigente na empresa, porém continuam a ser utilizados ou os dados contidos em seus bancos são ou devem ser incorporados ao sistema vigente.

Workflow: Palavra em Inglês que significa fluxo do trabalho, ou seja, como as tarefas se distribuem no meio empresarial e temporal. 


\section{Resumo}

Num cenário de constantes inovações tecnológicas e de surgimento de novos meios de informação, da viabilização de crescimentos produtivos e mesmo de novos conceitos organizacionais, fica difícil, muitas vezes, aproveitar-se toda a sinergia proveniente da combinação destas iniciativas.

A estruturação de dados dentro de empresas não é nenhuma novidade. Tampouco a utilização de recursos computacionais no auxilio ao projeto como o desenho auxiliado por computador ou o cálculo estrutural através da utilização de softwares.

Nesta dissertação, são abordados alguns aspectos sobre os benefícios de uma análise dos dados da empresa de modo a torná-los genéricos o suficiente e, paradoxalmente, específicos para os fatores criticos de sucesso da empresa. Ou seja, de como otimizar a utilização dos dados - vistos como informações - sem gerar, no entanto, redundâncias e esforços improdutivos.

Como exemplificação deste tipo de enfoque, trata-se o uso do dado (informação) na área de projeto, pois, nesta área, tida normalmente como altamente técnica, há uma penetração muito pequena dos dados corporativos, fato este que acaba segregando-a e consequentemente, tornando-a menos eficiente. 


\section{Abstract}

On a scenario full of technological improvements and with the appearing of new information media, the new production growing possibilities and even of new organizational concepts, usually, it is difficult to get all the possible synergy from the combination of all these initiatives.

Data structuring in companies is not a new issue, either the use of the computers to aid in the project area. Computer Aided Design and Computer Aided Engineering are examples of this use.

This thesis shows some aspects of the benefits provided by an enterprise data analysis that preserves a broad character to data and, paradoxically, gives them a strong focus on the key processes and critical factors of success. Or, in other terms, how to optimize the use of data - understanding data as information without generating redundancy and unproductive efforts.

To exemplify this kind of assumption, the project area use of data will be viewed, because, in this specific area, mostly known as a very technical area, there is a few penetration of the corporate data, causing a segregation and consequently bringing some inefficiency. 


\section{Introdução}

As técnicas de projeto e produção baseadas em CAD/CAM/CAE, o planejamento e controle de produção, os sistemas transacionais ${ }^{1}$ e os sistemas de informação gerencial ${ }^{2}$ dentre tantas outras ferramentas hoje disponíveis, usualmente funcionam de modo autônomo e independente, ou muito pouco relacionado, apesar da crescente melhoria das formas de relação entre os dados em redes de comunicação e de computadores. Este isolamento causa uma redundância de esforços ou até mesmo falhas por interpretações de informações mal trocadas.

Para se obter um aumento de qualidade desde o projeto do produto até sua extinção, é preciso utilizar ao máximo a sinergia obtida pelo correto interfaceamento ${ }^{3}$ das várias técnicas de projeto, produção e decisão, dentre outras.

1 Sistemas transacionais são os sistemas que auxiliam o controle das operações corriqueiras de uma empresa, como por exemplo o controle de estoques, de fluxo de caixa, de processos de manufatura e de ciclo de vendas.

2 Sistemas de informação gerencial são sistemas que, baseados nas informações vindas dos sistemas transacionais ou de outras fontes da empresa, fornecem visões mais claras do desempenho, de acordo com as necessidades dos niveis gerenciais.

3 Interfaceamento será usado neste texto como sendo o processo de troca ou transferência ou interpretação de um conjunto de informações e/ou comandos e/ou ações entre sistemas ou ambientes distintos, com ênfase na área de informática. 
Uma discussão muito em voga na indústria atual é sobre as deficiências no processo de comunicação, não o processo físico em si, bäseado em redes de telefonia, fibras ópticas, ondas em variadas freqüências e malhas de satélites dentre outros, mas o gerenciamento das divergências provocadas pela disputa do poder entre áreas funcionais em uma empresa.

Se por un lado os analistas de processos e os analistas de sistemas acreditam que a padronização ou a codificação é a saída mais indicada para gerar uma qualidade ótima de troca de informações, os analistas de negócios estão, muitas vezes, convictos de que a informação deve ter sempre sua forma nativa para que possa ser interpretada pelo receptor da forma o mais aberta possivel.

É frequiente que a troca de dados na empresa ocorra dentro deste ambiente, com maior ou menor sucesso em função do contexto: por exemplo, em áreas de projeto de engenharia, onde a difusão de normas é muito intensa, pode haver maior facilidade. Já em esferas estratégicas, onde o grau de subjetividade aumenta, normalmente há maior dificuldade.

Da determinação das necessidades e formas de informação depende o sucesso, por exemplo, de um Sistema de Informação ao Executivo (do Inglês: "Executive Information System" abreviado por EIS) ou de um Sistema de Suporte à Decisão (do Inglês: "Decision Support System" abreviado por DSS), pode-se estar tratando de informações estratégicas e relevantes ou simplesmente de relatórios operacionais, e, não é difícil encontrar empresas que investem muito dinheiro e recursos em um EIS, mas que, não o utilizam, ou pior, utilizam e obtém informações distorcidas e erradas.

Já a interface entre o Projeto Automatizado (CAD/CAE - Engenharia e Projeto Auxiliado por Computador) e o Planejamento da Produção (CAM/PCP - Manufatura Auxiliada por Computador e Planejamento e 
Controle da Produção) propicia uma troca de dados mais precisa, se bem que sempre balizada por procedimentos previstos, deixando pouca margem para eventos aleatórios. Para um ambiente competitivo onde a variabilidade vem se tornando uma constante, há de se ter especial cuidado com limitações na abrangência dos dados.

Segundo CORRÊA; SLACK (1994), o efeito das variabilidades gera uma análise mais abrangente e contempla todo 0 conjunto de interrelações organizacionais, sendo os principais fatores motivadores da flexibilidade da empresa: as incertezas do meio ambiente das indústrias e as necessidades do sistema prover variabilidade de saídas.

Poucos trabalhos (pesquisas), segundo os autores (ibidem), têm explorado os mecanismos que permeiam tais motivos, sendo abordadas no referido texto as relações entre as categorias: variabilidade de saidas, incerteza ambiental e flexibilidade dos sistemas de manufatura, afirmando que a flexibilidade possibilita também adaptações rápidas às mudanças nas saídas.

Controlar as incertezas reduz as necesșidades de flexibilização (que representam custos) e é este aspecto que se verifica na rápida e correta troca de dados entre áreas de empresas e, num âmbito mais globalizado e de empresa virtual ${ }^{4}$, entre diferentes empresas.

Em última análise, prevalece o jargão empresarial de que o cliente sempre tem razão, ou seja, é a partir das vontades expressas pelo mercado que se define tudo em uma empresa, desde a própria missão,

4 A respeito deste tema, há um artigo de CHESBROUGH; TEECE (1996) que tece consideraçōes sobre quando vale realmente a pena se constituir uma empresa virtual. 
até a escolha de um determinado mecanismo de controle de processo, passando pela linha de produtos, pela imagem institucional, pela definição dos preços e pelo perfil dos empregados.

Todos estão, ainda que implicitamente, conscientes dos "padrões" adotados pela empresa, e de como a empresa deve se apresentar ao público consumidor. Nesta dissertação não serão citados exemplos, mas há uma vastíssima literatura a este respeito, e, via de regra, qualquer livro sobre marketing ou megatendências está repleto de exemplos das mais variadas indústrias.

Como capturar e como transformar as informações do cliente em subsídios para o desenvolvimento de produtos é, portanto, o ponto crítico deste processo. 


\section{Objetivo:}

objetiva-se, neste texto, um aprofundamento no entendimento da interface entre a informação gerada ou armazenada dentro da empresa, seja ela originária de Bancos de Dados Corporativos Transacionais ${ }^{5}$ ou de outras fontes tais como interação com clientes $^{6}$ e fornecedores, pesquisas encomendadas e outras, e a atividade de projetar dentro da empresa (sendo o Projeto Automatizado uma das modalidades que sustentam esta atividade.

5 Banco de Dados Corporativo Transacional é todo o banco modelado a partir de processos e operações do dia a dia da empresa, e, portanto, carregado com dados desta natureza. Incluem-se nesta modalidade os bancos de dados resultantes de processos contábeis, de vendas (como gerenciamento de pedidos), de controle de produção no chão de fábrica e outros. Bancos Transacionais são constantemente alimentados com dados indexados por uma data de operação, gerando uma base dinâmica, ou seja, que varia em função do tempo. Porém, a maioria deles não dispõe de ferramentas de análise destes dados (e isto nem condiz com seus objetivos), sendo assim necessárias bases de dados de leitura e análise dos mesmo, tais como os "data warehouse" e os cubos de informações (a serem abordados por este texto).

6 Com o aparecimento do conceito de CRM (do inglês: Gerenciamento do Relacionamento com os Clientes), tem-se novamente uma ênfase no poder e importancia da palavra e atitude do cliente, agora subsidiada por um aparato tecnológico repleto de recursos tais como linhas diretas de comunicação ("call centers"), segmentações diversas, busca do entendimento do perfil psicográfico do cliente e outros. 


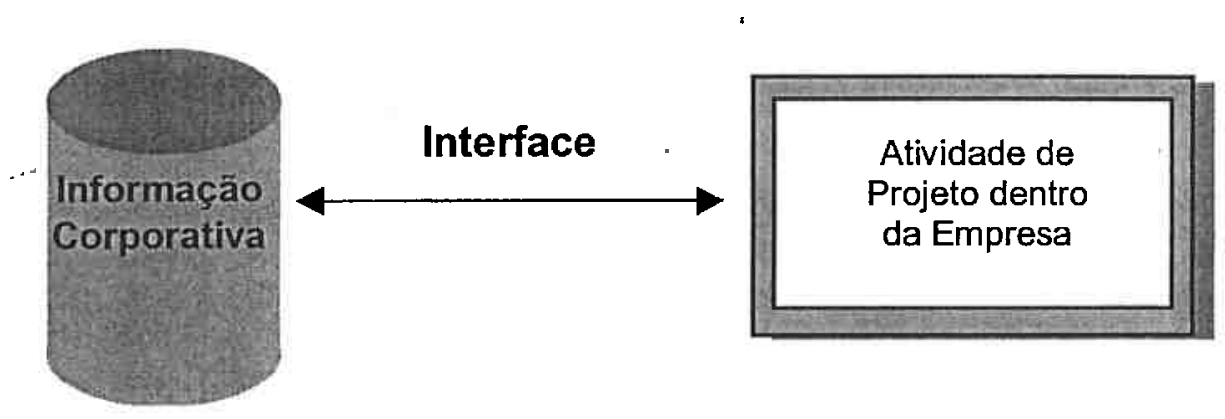

\section{Figura 1: Interface entre informações corporativas e atividade de projetar.}

Vários aspectos são relevantes nesta pesquisa, dentre os quais destaca-se três:

- Como identificar e modelar as informações indispensáveis no tipo de interfaceamento citado acima; ou seja, como mapear que tipos de subsidios poderiam ser fornecidos pelo conjunto de informações armazenadas pela empresa para suprir determinadas necessidades demandadas pela área de projetos.

- Como ocorre o fluxo de informações entre os setores corporativos da empresa e especificamente com a área de Engenharia e projetos, e quais fatores interferem na armazenagem, captura e leitura destas informações;

- De que forma a visão estratégica da empresa deve impactar nas mudanças tecnológicas para propiciar um contínuo incremento na qualidade das informações e de seu uso.

Abrangendo-se tais tópicos, pretende-se originar uma dissertação de mestrado com algumas recomendações voltadas à otimização do aproveitamento de informações dentro da empresa. Informações estas que deverão ser, portanto, abrangentes o suficiente para que se possa contemplar tanto as área mais técnicas da empresa, como as áreas de Engenharia, Manutenção e Manufatura, quanto as áreas 
chamadas de "Decisórias", que incluem Logistica, Marketing, e Planejamento ${ }^{7}$.

7 Cabe lembrar que a divisão da empresa aqui é meramente formal, não querendo dizer que áreas como a de Engenharia não tenham influência no processo decisório, ou que a área de Marketing não se envolva com processos técnicos. Trata-se apenas de uma formalização por preponderância. Na verdade, em diferentes graus, todas as área são afetadas 'e necessitam do uso da informação, incluindo área chamadas de Corporativas ou administrativas que incluem Recursos Humanos, Juridica, Financeira, Informática e outras. 
As áreas de automação industrial e de informática têm trazido ao linguajar do dia a dia empresarial termos e conceitos muitas vezes difíceis de serem compreendidos. Pela velocidade com que são introduzidos novos métodos e novas tecnologias (proporcional a velocidade em que os mesmos se tornam obsoletos), se a empresa não investir muito em treinamento técnico e administrativo, raramente conseguirá atingir resultados positivos.

Exemplo claro disso, e que pode ser verificado em inúmeras empresas, é a implantação do SAP, que pretende ser um sistema de gestão único dentro da empresa, mas que para obter sucesso, exige alterações em procedimentos internos muitas vezes radicais.

A preocupação quanto à clareza no entendimento muitas vezes fica restrita às esferas mais influentes na empresa (gerentes e diretores) ou mesmo às consultorias que muitas vezes são incumbidas da implantação de novas metodologias. Mas na verdade, quem vai utilizar as novas tecnologias que se apresentam quase sempre são as camadas mais operacionais, e estas são frequientemente esquecidas no momento de se investir em treinamentos.

As definições a serem expostas neste capitulo estarão sempre inseridas no contexto desta dissertação. No entanto, por serem baseadas em um senso comum e em uma série de textos, pode-se afirmar que são generalizáveis.

Um número mínimo de definições ou conceituações serão destacadas a seguir, para evitar possiveis redundâncias nos demais capítulos. são elas referentes a: características dos dados, informaçōes, operações, desenvolvimento de produtos e fluxo do trabalho ("workflow"). 


\subsection{Caracteristicas dos dados:}

o dado pode ser definido de inúmeras formas, das mais genéricas às mais especificas. Para os fins deste texto, o dado é visto como uma característica de um determinado objeto (RUMBAUGH; BLAHA; PREMERLANI; EDDY E LORENSEN; 1991), seja ele físico (uma medida, uma cor, uma temperatura, etc.) ou abstrato (uma percepção, uma estimativa, uma lei, etc.). 0 dado não é, portanto, necessariamente um número puro, mas um conjunto que pode ser composto de várias informações. Por exemplo, a temperatura em uma sala pode ser caracterizada por:

Tabela 1: Caracterização de um dado.

\begin{tabular}{|l|l|}
\hline Identificador único & Importante na recaptura do dado \\
\hline Identificação da sala & $\begin{array}{l}\text { Provavelmente relacionado a outro dado: } \\
\text { o da sala }\end{array}$ \\
\hline Unidade de medida & $\begin{array}{l}\text { Eventualmente também relacionado a } \\
\text { outro dado: o da unidade }\end{array}$ \\
\hline $\begin{array}{l}\text { Valor do dado } \\
\text { verificado }\end{array}$ & que é o dado propriamente dito \\
\hline Duração do dado & $\begin{array}{l}\text { intervalo até a próxima medição do } \\
\text { dado. }\end{array}$ \\
\hline
\end{tabular}

Para que o dado comece a se tornar útil, um conjunto mínimo de informações se torna necessário. Guardar algo como 161 não tem validade alguma, mas saber que às 15 horas do dia 18 de julho de 1999 a temperatura média na estufa 5 era de $161^{\circ} \mathrm{C}$ pode ser de alguma importancia. Se for conhecida uma seqüencia de dados semelhantes como este, pode-se ter um gráfico (Figura 2) de 
temperaturas no decorrer do tempo e pode-se, por exemplo, aplicar correções no decorrer do tempo para. que a temperatura permaneça sempre dentro de um intervalo especificado.

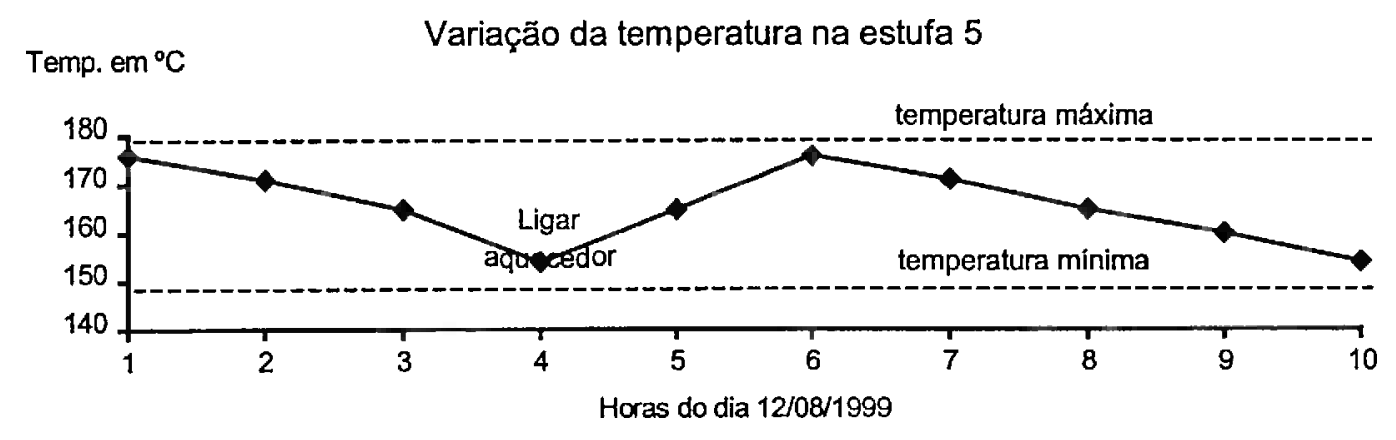

Figura 2: Variação da temperatura em uma estufa.

Note-se portanto que um dado é apenas parte de um contexto, e se justifica a partir de sua aplicabilidade.

Apesar da aparente simplicidade, alguns dados são bastante complexos: por exemplo, se tomarmos um ponto qualquer em um desenho em um sistema $C A D$ qualquer, serão necessários vários qualificadores para defini-1o, tais como: tipo de sistema de referencia (por exemplo cartesiano), posições relativas à origem do sistema de referência nos eixos $x, y$ e $z$, cor do ponto (ainda que seja uma entidade apenas representativa), identificação do desenho e assim por diante.

Além disso, (RUMBAugh; BLAHA; PREMERLANI; EDDY E LORENSEN; 1991) ○ dado deve obedecer a critérios de:

- Confiabilidade

- Acessibilidade

- Durabilidade 
- Segurança

\subsubsection{Confiabilidade:}

Dado confiável é aquele que pode ser considerado correto dentro de um espectro de critérios preestabelecidos, podendo ser utilizado para os fins estabelecidos por estes mesmos critérios. Desta forma, devem estar contidos no dado, na forma de qualificadores, os critérios ou as restrições na utilização do mesmo.

Daí se conclui que um dado não pode ser genérico de forma irrestrita. Um dado só pode ser considerado genérico dentro de um determinado contexto. Este contexto é definido por uma série de critérios.

\subsubsection{Acessibilidade:}

A acessibilidade dos dados é relacionada a alguns fatores:

Forma de armazenagem: uma vez armazenado, o dado deve poder ser recuperado, e, para tal, é preciso que o meio de recuperação do dado seja compatível com o meio de armazenagem do dado. Assim, se - dado foi armazenado em um papel, através de um código escrito, é preciso que na recuperação do mesmo, o código seja conhecido. A informação sobre o tipo de código utilizado deve ser também armazenada como qualificadora do dado. Se tratar-se de um dado armazenado em um banco de dados em um computador, é preciso ter a informação do tipo de banco de dados e do meio físico no qual ele está armazenado. Mais do que isto, é preciso dispor de formas de traduzir o código do banco de dados e disponibilizá-lo de forma útil ao usuário do dado. 
Flexibilidade do dado: Quanto mais formas de recuperação existirem para um mesmo tipo de armazenagem, mais flexível é o dado. Assim, um texto descritivo armazenado em uma gaveta é bastante acessivel em termos de flexibilidade. Basta que o recuperador conheça 0 código escrito (a língua), entretanto, ele pode ser incompreensivel caso não tenha havido uma padronização no momento da armazenagem.

Clareza: Esta característica permite que o dado seja rapidamente identificado e possa ser utilizado corretamente. Fatores que colaboram na clareza de um dado são uma modelagem correta, sem redundâncias, a utilização de formatos condizentes com ó conteúdo armazenado e o uso de uma nomenclatura conhecida e reconhecida.

Localização: Tanto quanto na logística do transporte, a importância da localização do dado é fundamental. O dado deve estar próximo do usuário o suficiente para que seja buscado cor a velocidade necessária ao seu uso. O dado pode ser copiado para que esteja em vários locais simultaneamente, chegando mais rapidamente ao seu destino, entretanto, neste caso é preciso extremo cuidado para que as cópias sejam mantidas sempre idênticas ou sincronizadas.

\subsubsection{Durabilidade}

É a característica que define a "vida útil" ou longevidade do dado, ou seja, por quanto tempo o dado precisa ser preservado. Esta definição varia em função do tipo de dado, ou seja, um dado fiscal, por exemplo pode ser preservado apenas pelo tempo estipulado legalmente (10 anos por exemplo), enquanto um dado de projeto deve ser preservado durante todo o ciclo de vida do produto e eventualmente de seu substituto e do substituto do substituto, dependendo da natureza do mesmo. Já um dado histórico deve ser preservado indefinidamente, uma vez que ele reflete um 
componenté da história da empresa, ou do país ou mesmo da humanidade.

Em sua passagem pelo tempo, o dado deve manter-se incorruptível, e deve haver mecanismos que garantam isto, como por exemplo, o controle através de datas de atualização dos dados. Em tempos de discos de leitura por raios laser e de comunicação por fibra óptica e ondas de rádio, é surpreendente que saibamos que há tanta informação armazenada em tumbas egípcias com tanto cuidado; informações estas, talvez muito mais fáceis de serem compreendidas do que as informações contidas na nave Apolo que está tão longe do sistema solar, porque não sabemos quem ou o que as verá...

\subsubsection{Segurança:}

Mais do que um atributo do dado em sí, a segurança deve ser do âmbito do banco de dados ou ainda do ambiente no qual os dados trafegam e são utilizados. Não se pode ter a confiabilidade dos dados se não forem observados cuidados com segurança, pois um dado não seguro pode ser facilmente adulterado. Também não se pode ter a acessibilidade dos dados se não for garantida a segurança, uma vez que os procedimentos de segurança é que viabilizam a entrega dos dados. Basicamente, o banco deve estar protegido com relação a acessos não autorizados seja para leitura, alteração, exclusão ou adição no mesmo, dependendo da natureza do dado e do perfil de quem está acessando o mesmo. Hoje, com $\circ$ advento das redes globais, mais especificamente da Internet, torna-se imperativo o uso de sistemas de proteção, com a utilização de recursos como "Fire-walls" 8 , softwares de encriptação", mecanismos de

8 "Fire-wall": termo inglês que designa uma barreira de proteção contra acessos indesejáveis. Geralmente trata-se de um aplicativo que atua nos servidores ou provedores de dados e regula os tipos 
identificação de conteúdos, chaves de acesso e outros. Não raramente, os custos de segurança tornam-se elevados, fazendo com que muitas empresas deixem seus dados vulneráveis, causando, eventualmente, danos que ultrapassam em muitas vezes o custo de uma implementação de urn sistema de segurança. Esquecem-se estas empresas que o verdadeiro valor delas está justamente nos dados em que ela acumula no correr de sua trajetória ${ }^{10}$.

de acessos segundo critérios configuráveis. Termo muito usado quando se fala em Internet.

9 A encriptação é um processo efetuado geralmente por um software que codifica os dados de forma a tornálos compreensiveis apenas por aqueles que detém a lógica do processo de encriptação. Este procedimento geralmente é utilizado em dados que serão submetidos a transporte em uma rede sujeita a acessos não desejados (Internet), e requer a utilização do software tanto no momento de codificar o dado (ponto de origem) quando no momento de decodificá-lo para lê-lo (ponto de chegada).

10 o acesso e a manipulação de dados bancários pelos chamados "Hackers" que desenvolvem meios de burlar os sistemas de segurança tem sido um desafio constante para as empresas do setor e para os profissionais da área, porém não são um caso isolado, havendo hoje ameaças como vírus de computadores, alterações em conteúdos da Internet $e$ inúmeros outros. Na verdade, $\circ$ complexo e ao mesmo tempo frágil ambiente das redes globais tem muitos pontos desconhecidos que podem se configurar em brechas no sistema de segurança . 


\subsection{Caracterização de Informação}

De acordo com TRONCHIN (TRONCHIN, V. J; 1997) para fins de "data warehousing", dados são os componentes básicos, a partir dos quais a informação é criada. Informação são dados inseridos em um contexto. Contexto é a situação que está sendo analisada. A partir da informação obtém-se conhecimento, que permite tomar decisões, trazendo poder e vantagem competitiva.

No texto, o autor citado ainda reforça que para transformar o dado em informação é necessário um individuo, que é aquele que colocará - dado no contexto adequado. Neste momento, o dado adquire significado, semântica, transformando-se em informação. Só neste instante ele passa a ter valor para o propósito do contexto

Ainda que exista uma sensivel diferença entre dado e informação, muitas vezes neste trabalho poderá parecer haver um descuido semântico, uma vez que um dado contextualizado (informação) continua a ser um dado, e como o termo "dado" é mais genérico, muitas vezes preferirei usá-lo ao invés do termo "informação".

\subsection{Caracterização de Operações}

No contexto presente, "Operações" é vista como um sistema ou um conjunto de sistemas que suportam o dia a dia operacional da empresa; ou seja, todas as operações que, direta ou indiretamente, influem na produção do produto (ou serviço) e, acessoriamente, na contabilização do mesmo, tanto para fins de controle interno tais como movimentação de estoques, controle de qualidade, estatísticas de vendas, levantamentos de custos, como para controles legais tais como cadastros em contas contábeis, livros fiscais e outros dispositivos normativos de exigência governamental ou da própria indústria. 
Segundo GIANESI; CORRÊA (1994), "Operações" tem uma definição mais restrita: para os autores, (ibidem, pg. 30): "a função de operações de uma organização é a parte responsável por produzir seus produtos (ou serviços). Um sistema de operações, seja de que empresa for, apresenta alguns elementos básicos..."

$\mathrm{Na}$ definição de sistema de operações, os autores prosseguem: "... sistema necessita, antes de tudo, de objetivos bem definidos. 0 sistema contém também um processo de transformação, responsável por converter entradas (recursos) em saidas especificadas. Possui, ainda, um sistema de controle, responsável por ajustes no processo que visem garantir que as saídas ou resultados sejam os esperados. Flutuações aleatórias como, por exemplo, atraso de fornecedores, quebra de equipamentos e rotatividade de mão-de-obra fazem com que os resultados produzidos possam estar fora das especificações, tornando a função de controle essencial."

$\mathrm{Na}$ visão dos autores, portanto, "Operações" está muito intimamente ligada a produção, principalmente nos processos de manufatura.

Para esta dissertação, este termo fica um pouco mais amplo, uma vez que, para sistemas integrados, ainda que numa visão utópica, todos os processos da empresa tornam-se essenciais na operação da empresa.

Os autores acima citados relacionam "Operações" com outras funções da empresa de forma a destacar a função de manufatura ${ }^{11}$. A Figura 3 mostra como se comunicam as funções segundo os autores.

11 Ainda que o texto se refira explicitamente a "Serviços", é muito forte a tendência em se enfatizar a manufatura, talvez pela própria característica dos autores. Isto de forma alguma diminui o 


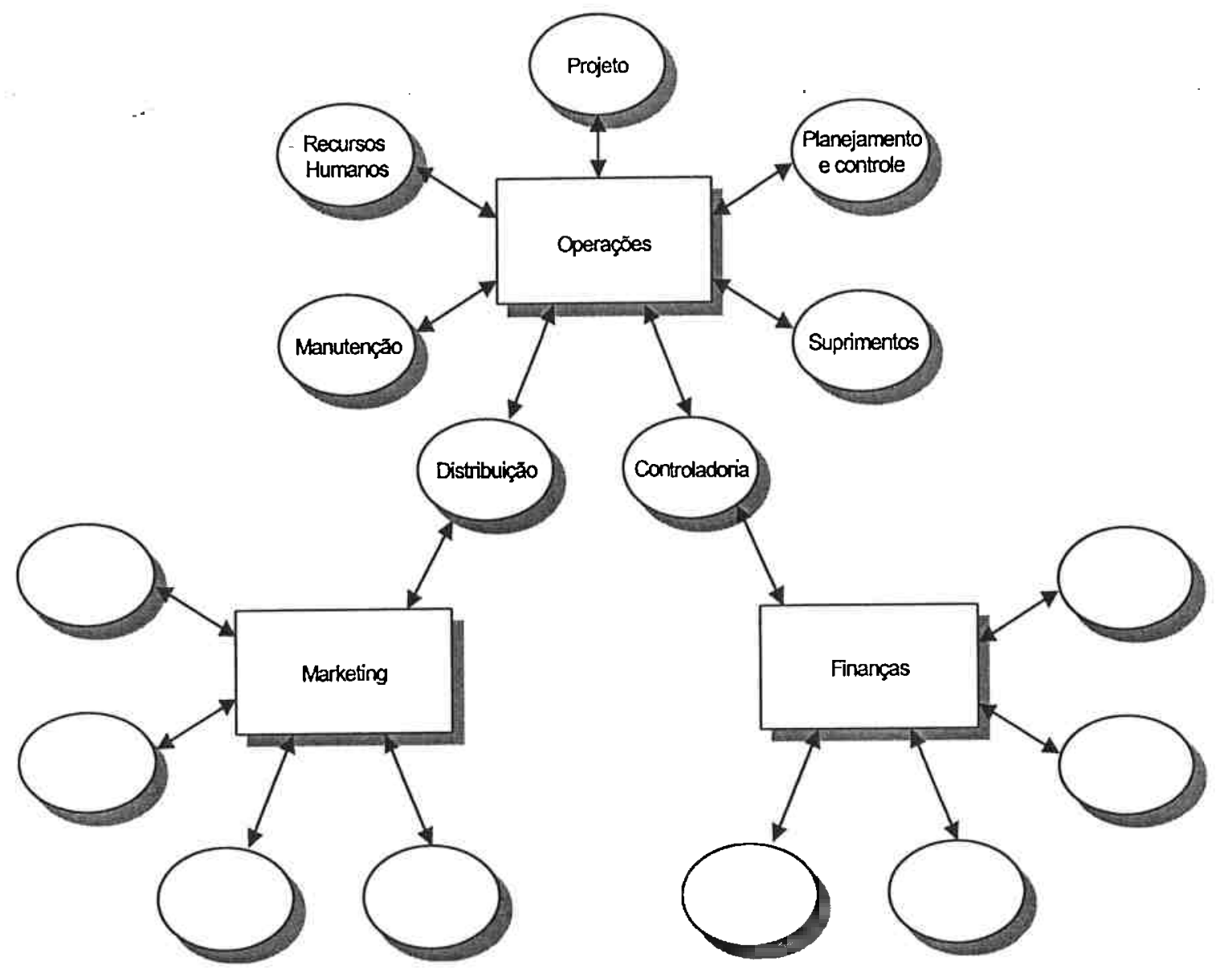

Figura 3: Algumas interfaces da função de operações com outras funções da empresa. (GIANESI; CORRÊA (1994)).

Do ponto de vista organizacional, a estrutura da empresa pode ser vista desta forma -- ou de outras, conforme a tendência do negócio e da indústria -- mas do ponto de vista de integração de sistemas, - nível de compartimentação das funções tem uma hierarquia mais homogênea, ou seja, coloca-se lado a lado funções como manufatura, vendas ou projeto, e todas compõem as "Operações" da empresa.

valor do texto citado, mas acentua a similaridade que pode ser verificada entre manufatura e serviços em muitos aspectos. 
Exemplo desse tipo de estruturação é o conceito da SAP (SAP (1999)), já citado anteriormente.

Na Figura 4 o centro não é um processo ou uma área, mas a base de dados e a estrutura do software de gestão.

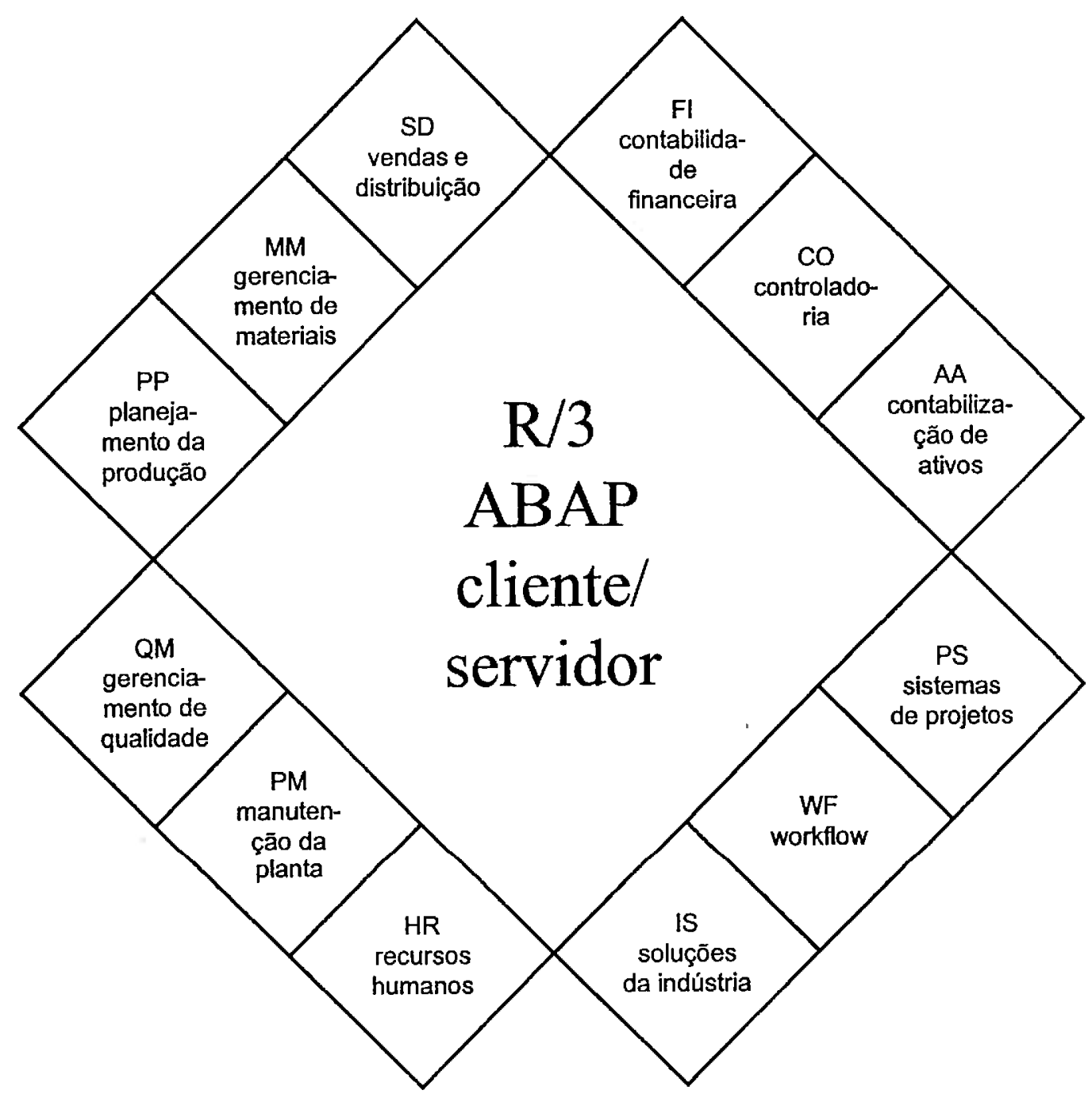

Figura 4: Estruturação integrada de áreas em uma empresa segundo a visão da SAP (SAP (1999)). 
Com isto, a SAP, assim como outras empresas do ramo de softwares de gestão, enfatiza a importância do dado, como elemento de ligação entre as várias áreas da empresa.

Há, portanto, uma diferença entre a estruturação administrativa e funcional e a estruturação sistêmica ${ }^{12}$. Uma não anula ou exclui a outra: são apenas visões com diferentes objetivos.

A verdade, porém, é que para a operação propriamente dita da empresa, prevalece a visão administrativa e funcional, e a visão sistêmica sintetiza a estrutura sobre a qual a empresa desempenha seus planos a longo prazo, ou seja, na direção de seus objetivos.

\subsection{Caracterização de Desenvolvimento de Produtos:}

Trata-se dos sistemas e/ou procedimentos que dão subsidios e efetivamente desempenham o desenvolvimento do produto, ou seja, o projeto do produto, a pesquisa, a homologação, o teste, a implantação e as demais etapas de desenvolvimento de produtos.

Conforme apresentado por KAMINSKI (2000), "o processo de desenvolvimento de produtos pode ser definido como um conjunto de atividades, envolvendo quase que todos os departamentos da empresa, que tem como objetivo a transformação de necessidades de mercado em produtos ou serviços economicamente viáveis. o processo de desenvolvimento de produtos engloba desde o projeto do produto (fase principal) até a avaliação do produto pelo consumidor, passando pela fabricação."

12 Entendendo-se aqui o termo "sistêmica" como sendo aquilo referente a sistemas de informática apenas. 
Segundo o autor (ibidem), há seis principais aspectos a serem considerados no. desenvolvimento de um novo produto: administrativos, técnicos, financeiros, econômicos, juridicos e legais e de meio ambiente.

Fica claro, então, que não se pode pensar em desenvolvimento como sendo uma atividade puramente técnica na qual o desenvolvedor exerce autonomamente seu poder criativo até que seja gerado o produto. Ao contrário, há um envolvimento multi-disciplinar e extra-empresarial, com a participação desde o acionista da empresa até o consumidor final e suas ansiedades. Desenvolver um produto é conseguir traduzir todas as variáveis relevantes envolvidas -tais como as citadas -- em um ambiente coeso e ao mesmo tempo muito flexível, de modo a atingir um resultado muito próximo da vontade do mercado. Isto ressaltando duas variáveis fundamentais que são o tempo ou a velocidade e o custo ou o orçamento.

\section{5 "Workflow" - Fluxo de trabalho ou sequiencia de tarefas:}

o conceito de "workflow" tem sido fundamental dentro do ambiente empresarial, pois através dele, tornam-se mais claros os relacionamentos entre níveis diversos da empresa, sejam eles de caráter hierárquico, funcional ou de qualificação técnica.

o exemplo mais elementar do "workflow" é o do antigo "office boy" que leva uma proposta de desenvolvimento de projeto das mãos do gerente de engenharia até o gerente financeiro. Este, analisa a proposta (basicamente o custo) e a envia ao gerente do jurídico, que por sua vez avalia os impactos legais da proposta, e novamente a envia ao gerente da área fiscal... Este ciclo continua até que todos os "níveis" necessários tenham sido consultados, e então, caso não haja nenhuma ressalva, a proposta é assinada pelos 
gerentes, fazendo com que o documento volte até as mãos do gerente de engenharia.

Visto desta forma, o "workflow" é extremamente pouco prático durante o tempo em que o documento circula, o gerente de engenharia ou já resolveu iniciar o projeto, ou o reavaliou e desistiu do mesmo -- o tempo despendido no processo pode ser inviável, o cíclo é extremamente linear, e o benefício é questionável.

o que se procura fazer, é mapear todos os possíveis fluxos e automatizá-los ao máximo. Decisões que dependam de vários responsáveis podem ser abordadas em conjunto para acelerar os processos; procedimentos formais (por exemplo aprovação de despesas ordinárias) podem ser feitas em bateladas, e, principalmente, ao se criar padrões nos documentos envolvidos nos fluxos, a análise dos mesmos torna-se mais rápida e objetiva.

Como suporte, a informática dispõe de pacotes de aplicativos que permitem a geração de níveis hierárquicos, a padronização de documentos, o disparo automático de processos ("triggers"), e a troca de mensagens e documentos através de correio eletrônico. Também aplicativos em internet têm sido feitos, ampliando, desta forma, a abrangência do "workflow" a uma esfera global. 


\section{Projeto Mecânico Assistido por Computador}

A busca da melhoria no processo de projetar tem origem nos primórdios da história dos projetos de engenharia, a partir do momento em que se percebeu que a etapa do projeto era fundamental para o bom resultado final do produto.

Os primeiros projetos surgiam nas paredes das cavernas da préhistória. Os homens primitivos lançavam-se em suas empreitadas, geralmente grandes caçadas e as estampavam nas paredes, como forma de ensiná-las a seus semelhantes.

Na idade antiga, predominaram grandes projetos civis e navais que precediam a execução do mesmo. Já era possível utilizar o projeto várias vezes e aperfeiçoá-1o em função da experiência anterior.

$r$

No renascimento, grandes nomes se destacaram na área de projetos, e, com certeza, Leonardo da Vinci foi um dos que mais colaborou em quantidade e qualidade de projetos voltados a engenhos mecânicos. Seus registros (Figura 5) foram base para muitos outros projetos e até hoje impressionam pela clareza na representação. 


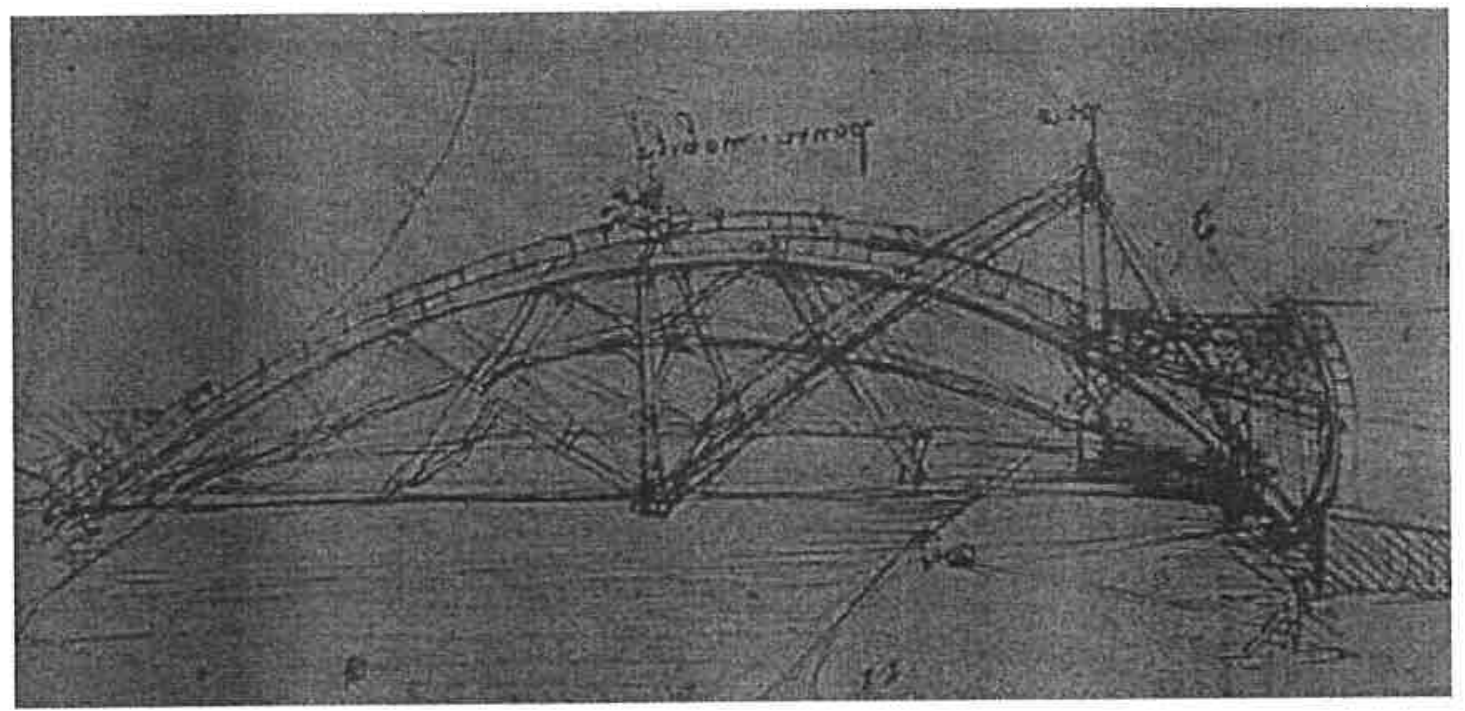

Figura 5: Projeto de ponte levadiça de Leonardo da Vinci (Fonte: Internet: http://www.museoscienza.org/english/leonardo)

Mas foi na revolução industrial durante o século XIX que a importância do projeto mecânico foi reconhecida de fato. Com a produção em grande escala, o projeto passou a ser estudado com mais profundidade, pois sua reprodutibilidade em larga escala torna-se de grande impacto.

De lá para hoje a evolução dos métodos de projeto envolveram desde pequenas melhorias nas formas de representação até verdadeiras revoluções na forma de organização das equipes de projeto. Neste panorama, o advento do computador representou mudanças muito mais radicais. Não se pode encará-lo como uma mera ferramenta de desenho: suas capacidades de reduzir tempos de discussão entre equipes multidisciplinares, de garantir a precisão e a qualidade dos dados, de melhorar e facilitar a representação de objetos e sistemas e outras, não podem ser abordadas isoladamente, caso contrário, muito do benefício gerado pelo uso do computador será perdido. 
- CAD no projeto mecânico surgiu com reais capacidades de aplicação nos anos 60, impulsionado principalmente pela corrida espacial e por estudos dos grandes centros de pesquisa de universidades americanas, mas foi apenas nos anos 80 que seu uso se difundiu, principalmente por conta da popularização dos computadores pessoais. "Softwares" populares surgiram nesta época, como o Autocad (1980) e estações de trabalho ficaram mais simples de serem operadas em indústrias.

Desde então o esforço na utilização do CAD integrado com outros recursos tornou-se um desafio, onde os resultados surgem a cada dia, mostrando o quanto se pode ganhar em produtividade e qualidade, além de redução de custos.

\subsection{CIM}

Com o surgimento do conceito do CIM (Manufatura integrada por computador), as várias áreas envolvidas no processo do projeto passam a poder estar integradas. Segundo KAMINSKI (2000), "a decisão pelo CIM é uma decisão estratégica, e não econômica. Os aspectos econômicos devem apenas determinar a velocidade de sua implementação."

- CIM não é uma ferramenta, nem tão pouco um conjunto de ferramentas, mas sim um conceito que agrega várias tecnologias e metodologias. Em BARRETO (1991) são listadas vária definições para - conceito, todas relacionadas ao conjunto da manufatura, a automação e a integração.

\subsubsection{CAD}

- CAD, que significa (em inglês) projeto auxiliado por computador pode ser visto como um dos componentes do CIM. 
Segundo GROOVER; ZIMMERS (1984), algumas aplicações comuns do CAD, de uma forma bastante genérica são:

- Análises de esforços estruturais;

- Respostas dinâmicas de mecanismos;

- Cálculos de transporte de calor;

- Programação de controles numéricos;

Hoje há um nível de especialização bastante acentuado na área de softwares, de forma que para cada um dos usos acima citados, uma nova categoria pode ser criada, surgindo pacotes de CAD específicos para projeto mecânico, eletrônico, de softwares, etc.

\subsubsection{CAM}

- CAM (manufatura auxiliada por computador) também é um componente do CIM, e é definido como sendo o uso de componentes de sistemas para planejar, gerenciar e controlar operações de uma planta de manufatura. Duas principais categorias de CAM podem ser identificadas: monitoração e controle computacional e aplicações de apoio à manufatura.

Alguns exemplos de aplicações de CAM são:

Controle numérico: programas preparados para ferramentas automatizadas;

Planejamento de processos automatizado: onde são preparadas listas de sequiencias de operações requeridas para processar um determinado produto ou componente; 
Geração de padrões: pelo computador determina-se tempos padrão para operações de produção;

Programação da distribuição dos tempos para a produção;

Planejamento das necessidades de materiais e

Controles de chão de fábrica.

\subsection{3 o ciclo de produto e CAD/CAM}

- CAD/CAM mostra-se presente em várias etapas do ciclo de vida de um produto, desde sua concepção até sua extinção, em diferentes graus e em função do tipo de produto.

Segundo GROOVER; ZIMMERS (ibidem), seus pontos de maior interferência são:

- Conceituação do produto (CAD);

- Projeto de engenharia (CAD);

- Testes e prototipação (CAD/CAPP);

- Planejamento do processo (CAPP);

- Logística (CAPP);

- Produção (CAM);

- Controle de qualidade.

\subsubsection{Automação e CAD/CAM}

A atividade da produção pode ser dividida em quatro categorias principais (GROOVER: ZIMMERS (1984)): 
- Processos de fluxo contínuo;

- Produção en massa de produtos discretos;

- Produção em batelada;

- Produção "job-shop"

A Tabela 2 a seguir especifica aproximadamente $\circ$ relacionamento do CAD/CAM com cada um dos tipos de produção citados:

Tabela 2: Tipo de automação em função do tipo de produção (GROOVER; ZIMMERS (1984)).

\begin{tabular}{|l|l|}
\hline Categoria & Necessidade de automação \\
\hline Processos de fluxo contínuo & $\begin{array}{l}\text { Fluxo do processo do início ao fim; } \\
\text { Tecnologia sensorial disponível para medir variáveis de processo } \\
\text { importantes; } \\
\text { Controles sofisticados e de estratégias de otimização; } \\
\text { Plantas automatizadas }\end{array}$ \\
\hline $\begin{array}{l}\text { Produção em massa de } \\
\text { produtos discretos }\end{array}$ & $\begin{array}{l}\text { Máquinas de transporte automatizado; } \\
\text { Linhas de montagem automatizadas; } \\
\text { Robôs industriais; } \\
\text { Monitoração da produção computadorizada }\end{array}$ \\
\hline $\begin{array}{l}\text { Produção em batelada } \\
\text { (célula) }\end{array}$ & $\begin{array}{l}\text { Controle Numérico (CN, CND, CNC); } \\
\text { CIM; } \\
\text { Robôs }\end{array}$ \\
\hline $\begin{array}{l}\text { Produção “job-shop" } \\
\text { (funcional) }\end{array}$ & CN e CNC \\
\hline
\end{tabular}

A definição de CAD segundo GROOVER; ZIMMERS (ibidem) abrange qualquer tipo de atividade de projeto que envolva $\circ$ uso de computadores para desenvolver, analisar ou modificar um projeto de engenharia. Os CADs modernos disponibilizam interfaces homem/máquina simples o suficiente para que haja uma interação rápida e precisa. Segundo a referência citada, alguns dos motivos para se implementar um sistema de CAD são:

- Para aumentar a produtividade do projetista;

- Para melhorar a qualidade do projeto; 
- Para melhorar a comunicação entre as várias partes envolvidas no projeto;

- Para se criar bancos de dados para manufatura.

Cada um destes motivos suscita inúmeras discussões, mas indubitavelmente, com maior ou menor grau, todos justificam seu uso.

\subsubsection{CAE}

CAE, engenharia auxiliada por computador, segundo KAMINSKI (2000), "pode ser entendido como sendo os sistemas computacionais envolvidos diretamente com os cálculos de engenharia e simulação numérica dos fenômenos físicos. Como exemplos podem ser citados: programas baseados no método dos elementos finitos para análise estrutural, análise térmica, etc.; programas de simulação de circuitos eletrônicos; programas para análise e síntese de mecanismos, etc."

\section{2 o Processo de Projetar e as Aplicações do Computador}

Dentro do processo de projetar o computador pode ser envolvidas em várias etapas. Segundo SHIGLEY (1989), as tarefas básicas e seus relacionamentos mínimos são os vistos na figura 6 .

Segundo o modelo proposto, a interação com o CAD ocorre a partir da etapa de síntese, com as seguintes atividades correlatas:

- Modelagem Geométrica;

- Análise de engenharia e

- Revisão e avaliação do projeto 


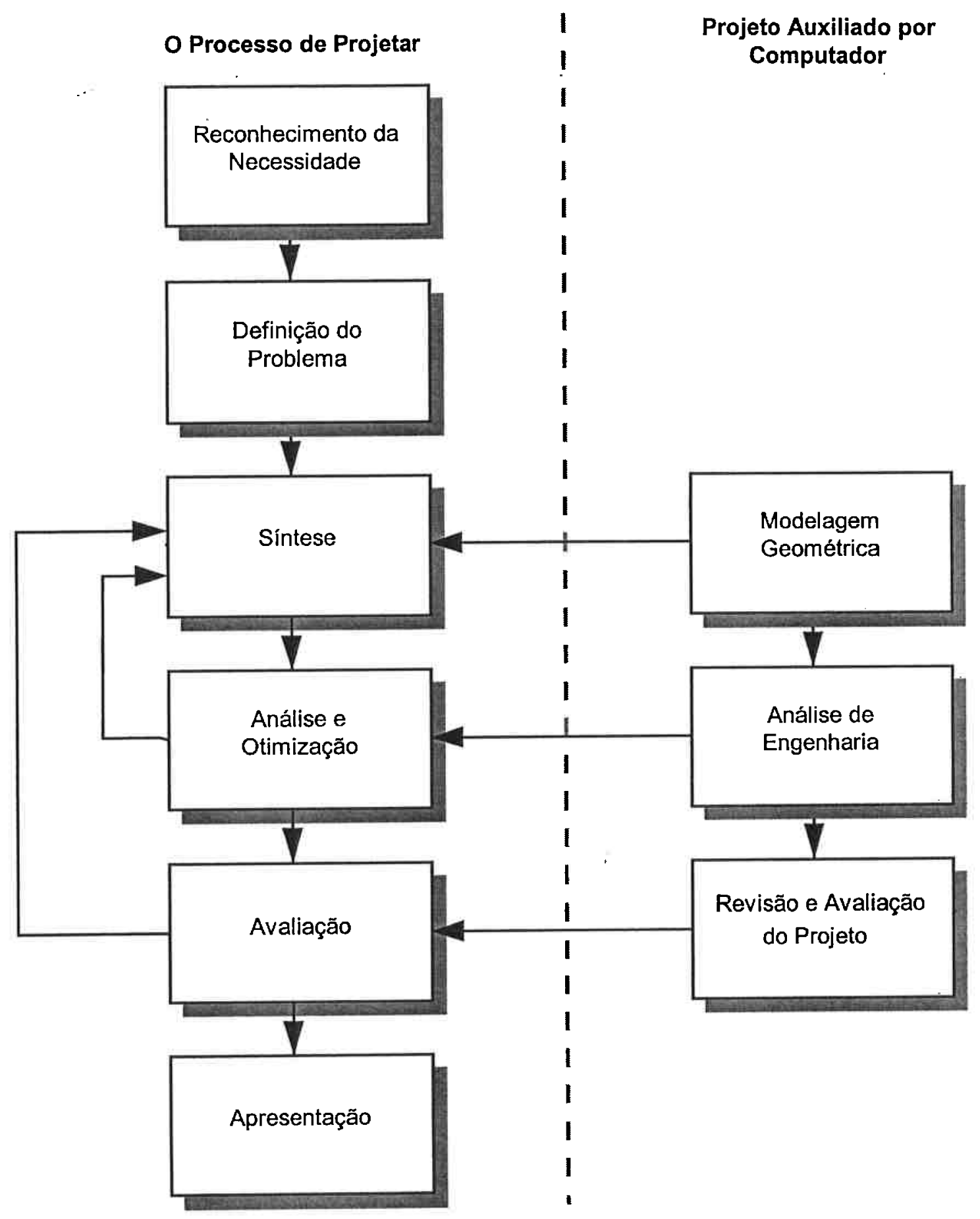

Figura 6: As várias etapas de um projeto (SHIGLEY (1989) adaptado) . 


\subsection{Modelagem Geométrica}

É a etapa da descrição matemática da geometria do objeto. Esta descrição permite a visão e a manipulação das formas físicas do objeto projetado. Através de uma interface com o operador (geralmente um micro computador ou uma estação de trabalho), é possivel criar entidades geométricas como pontos, curvas ou primitivas sólidas e depois editálas, girando-as, copiando-as, etc., gerando interpretações matemáticas do computador.

A "visão" que nos é dada através da tela do computador, nada mais é, portanto, que uma representação de um modelo matemático. Dependendo do tipo de software de CAD, esta representação é classificada em:

2D - uma representação em um único plano, útil para diagramas, fluxogramas, para aplicações de captura esquemática, etc.;

$2^{1} 2 \mathrm{D}$ - utiliza uma coordenada de profundidade, porém tem a limitação de na permitir manipulações nesta dimensão. a forma de trabalho é em 2D, porém, consegue-se representações em 3D;

3D - hoje, praticamente todas as ferramentas CAD oferecem esta capacidade, permitindo a representação de sólidos e sua total manipulação

Nas representações em 3D há ainda dois modos de visualização: o "Wire-Frame" que utiliza pontos e curvas, dificultando o reconhecimento da profundidade e o sólido que permite a visão do volume do objeto como ele realmente é. Há ainda um terceiro modo que é $\circ$ da realidade virtual, onde se utiliza texturas, interferências luminosas e uma série de outros recursos que mais se aplicam a finalidades artísticas ou de publicidade, mas que 
podem vir a ter papel importante no campo do projeto de engenharia.

\subsection{Análise de Engenharia}

Alguns tipos de análises são necessárias em praticamente qualquer tipo de projeto de engenharia. Estas análises podem incluir cálculos de esforços, fadiga, transferências de calor ou mesmo o uso de equações diferenciais que descrevam $\circ$ comportamento dinâmico do sistema projetado.

Há vários softwares que, ou no próprio CAD ou interligados ao CAD, oferecem interfaces para a implementação das mais variadas informações que ajudam nos cálculos pertinentes ao projeto.

Dos mais conhecidos, pode-se citar:

Softwares de análise de propriedades de massa: disponibiliza informações sobre o sólido projetado incluindo área superficial, peso, volume, centro de gravidade e momento de inércia. Para superficies planas (ou cortes), fornece perimetro, área e propriedades de inércia;

Análise de elementos finitos: possibilita a divisão do objeto em vários elementos que podem ser tão pequenos quanto se queira (ou quanto a capacidade do conjunto equipamento/software permita) e a análise de cada um deles no que tange a esforços, transferência de calor, interferências, etc., geralmente representados graficamente pelo uso de cores e quantificado em tabelas.

o uso destes recursos permite a escolha de formas e materiais que se adequem melhor ao sistema projetado. 


\subsection{Revisão e Avaliação do Projeto}

Para reduzir a possibilidade de erros de dimensionamento, rotinas semi-automáticas de dimensionamento e de cálculo de tolerância podem ser utilizadas.

A utilização de várias camadas de desenhos sobrepostas é útil na verificação de interferências, como por exemplo no projeto de plantas industriais onde o projeto da tubulação pode ser feito em algumas camadas e o de civil e arquitetura em outras, e no confronto das camadas são verificadas interferências. Hoje já é possivel trabalhar simultaneamente no projeto com várias equipes e em várias camadas, verificando-se as interferências logo nas etapas de sintese.

Também é particularmente útil nesta etapa o uso de recursos de animação que permitem que se "caminhe" pelo desenho ou que as partes do projeto se movimentem em suas articulações.

\subsection{Esboço Automático}

Como resultado de todas as inserções de dados, os sistemas CAD podem gerar ainda plantas, cortes, perspectivas ou detalhes impressos em papel ou até mesmo listas de materiais, especificações e modelos sólidos feitos em resinas ou em materiais mais próximos aos especificados pelo projeto.

\subsection{Base de Dados Associada ao Projeto}

Outra caracteristica dos sistemas CAD é a geração de uma base de dados contendo todas as informações referentes ao projeto e armazenadas eletronicamente. Este recurso que pode, aparentemente 
ser apenas uma decorrência natural, acaba sendo, na verdade, uma das peças principais que justificam o uso de ferramentas CAD. São estas bases de dados que vão possibilitar a troca de dados entre vários projetos, a utilização destes dados como parte de um outro projeto, o relacionamento entre as várias áreas envolvidas no projeto, desde os projetistas de componentes até as áreas de produção, planejamento e até mesmo de marketing.

A base de dados da manufatura é uma base de dados integrada de CAD/CAM. Ela inclui todos os dados gerados durante o projeto (dados de geometria, lista de materiais e partes, especificações de materiais, etc.) bem como dados adicionais necessários para a manufatura, muitos deles baseados no projeto do produto. A Figura 7 mostra como as bases de dados geradas pelo CAD/CAM se relacionam com a produção em companhias tipicamente orientadas à produção. 
CAD

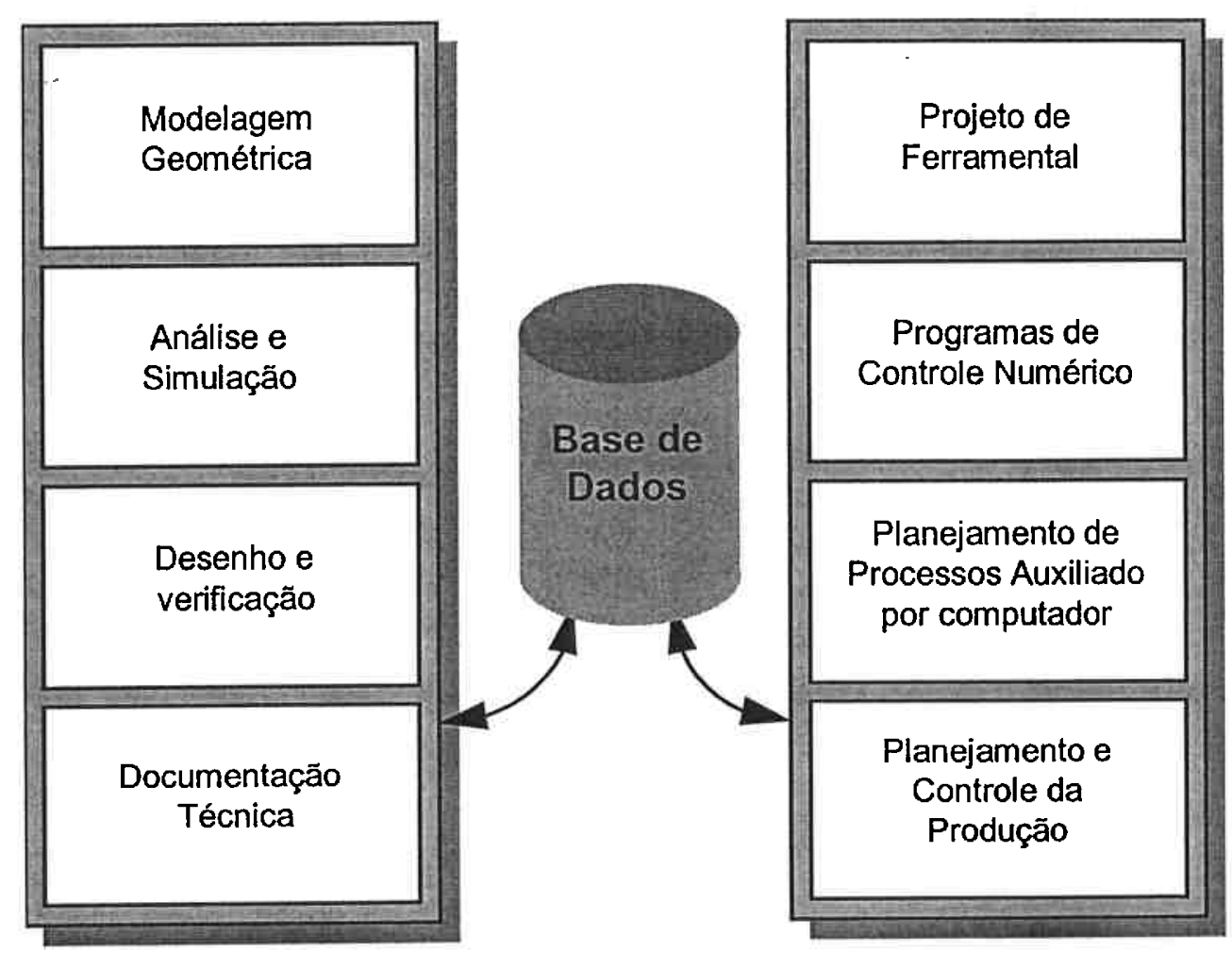

Figura 7: Relacionamento CAD/CAM através das bases de dados (Adaptado de KAMINSKI (2000)).

\subsection{Benefícios do uso do Projeto Auxiliado por Computador}

Há muitos benefícios no uso do CAD, porém somente alguns podem ser claramente quantificados. Outros são intangíveis, refletindo-se no aumento da qualidade do trabalho, na geração de informações mais pertinentes e úteis e na melhoria do controle do projeto como um todo. Algumas das vantagens mais reconhecidas são descritas a seguir. 


\subsubsection{Aumento de Produtividade no Projeto}

Além de permitir equipes menores e mais dinâmicas, ocasiona a redução dos custos de projeto e respostas mais rápidas ao mercado. Segundo dados de vendedores citados por GROOVER; ZIMMERS (1984), a melhora na produtividade de uma equipe de projetistas sem CAD para uma com CAD pode ser de desde 3 vezes até mais de 10 vezes, dependendo muito do tipo de aplicação.

Alguns dos fatores que influenciam nesta relação são:

- Complexidade dos desenhos de engenharia;

- Nivel de detalhes requerido pelos desenhos;

- Grau de repetição nas partes do desenho;

- Grau de simetria nas partes do desenho e

- Número de bibliotecas de entidades normalmente usadas e a extensão de seu uso.

\subsubsection{Tempos menores de Planejamento e Preparação do Produto}

o projeto auxiliado por computador interativo é inerentemente mais rápido do que os processos tradicionais de projeto. Ele reduz também o tempo de produção de relatórios e listas, que normalmente são feitas paralelamente. De tal forma que o tempo total de projeto tende a se reduzir muito e os novos produtos passam a ser lançados muito mais de acordo com os requisitos do mercado.

\subsubsection{Análise do Projeto}

As rotinas de análise de projeto disponiveis nos sistemas CAD ajudam a consolidar o processo de projeto através de um padrão 
mais lógico de trabalho. Ao invés de se proceder a idas e voltas entre grupos de projeto e de análise, uma mesma pessoa pode efetuar o projeto e a análise simultaneamente através de uma estação de trabalho. Isto faz com que as concepções iniciais do projeto já se aproximem bastante de soluções ótimas.

\subsubsection{Menor Quantidade de Erros de Projeto}

Erros de entrada, transposição e propagação são mais facilmente evitados em sistemas CAD, através de mecanismos de consistência inerentes à própria forma de trabalhar. Além disso, há muito menos inserção de dados e muito mais reaproveitamento de dados, além de se utilizar graus de acuracidade muito maiores, evitando erros comuns em projetos convencionais causados por problemas de paralaxe.

\subsubsection{Maior Precisão nos Cálculos de Projeto}

Como os computadores atuais trabalham com valores muito precisos (número de algarismos significantes muito grande), os cálculos matemáticos tornam-se virtualmente incontestáveis (muito mais precisos do que a maioria dos objetos que eles representam).

Além disso, em sistemas paramétricos (a serem vistos mais a diante), se for alterado um valor em uma parte do projeto, esta alteração se refletirá automaticamente no restante do projeto, sem que sejam necessários novos cálculos.

\subsubsection{Desenhos mais Compreensiveis}

Um desenho feito em CAD pode ser visualizado das mais variadas formas, desde descrições por escrito até animações em realidade 
virtual. o entendimento das exibições varia aproximadamente de acordo com a Figura 8 proposta em GROOVER; ZIMMERS (1984).

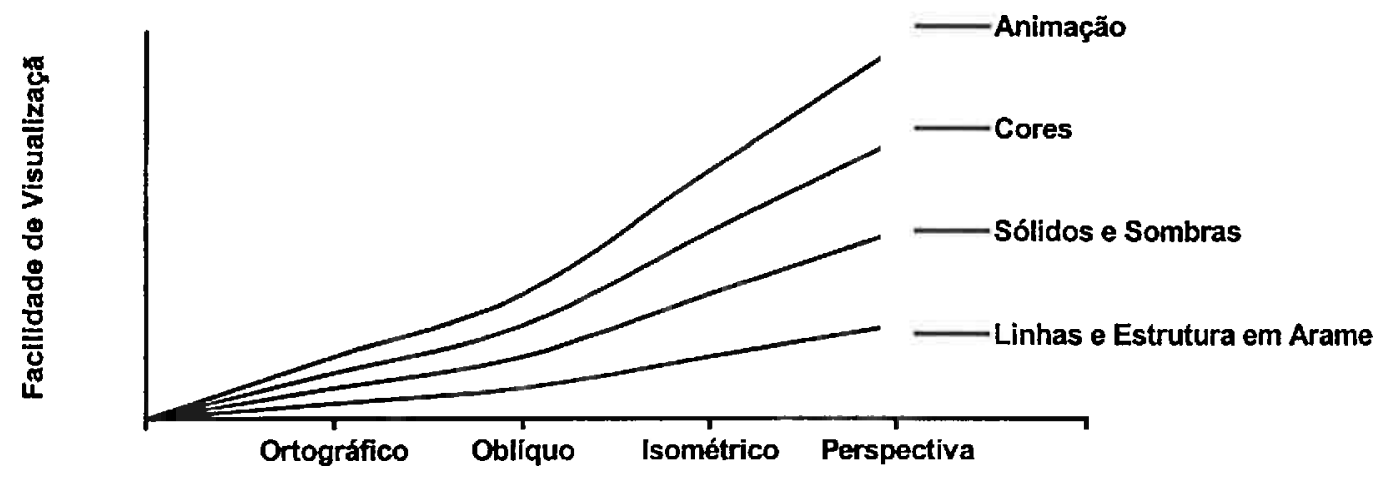

Figura 8: Facilidade de visualização de desenhos em CAD (GROOVER; ZIMMERS (1984))

\subsubsection{Processos de Melhorias para Mudanças na Engenharia}

o controle e a implementação de mudanças na engenharia são substancialmente melhorados com 0 CAD, principalmente pela facilidade de acesso aos dados gerados, proporcionando uma grande facilidade de consulta e comparação entre projetos novos e já feitos.

\subsubsection{Beneficios na Manufatura}

Em função do compartilhamento da mesma base de dados, uma série de benefícios se estendem também à manufatura:

- Projeto de mancais e ferramentas

- Programação de controle numérico de partes 
- Planejamento de processos auxiliado por computador

- Listas de montagem para produção

- Inspeção auxiliada por computador

- Planejamento de robótica

- Tecnologia de grupo

\subsection{A Construção nos Softwares de Sistemas Gráficos}

Na operação de sistemas gráficos, uma variedade de atividades é feita, podendo ser divididas em três categorias:

- Interação com interface gráfica para criação e edição de imagens;

- Construção de modelos de algo físico fora do ambiente gráfico (modelos de aplicação):

- Importação de modelos previamente montados.

A primeira categoria é a que está mais próxima da atividade do projetista tradicional, envolvendo domínio não só de técnicas de projeto, mas também de relacionamento homem máquina. A segunda diz respeito a integrações mais complexas, onde ou o usuário é um especialista em ferramentas $C A D$ em baixo nivel (linguagem de máquina) ou há fluxos entre diferentes sistemas, muitas vezes não CAD, que geram instruções e códigos a serem interpretados pelo CAD. Esta capacidade é de extremo valor, possibilitando realimentações entre áreas de projeto, produção, planejamento, etc. E, finalmente, a terceira categoria envolve 0 
reaproveitamento de trabalhos já efetuados ou a integração de áreas de projeto em torno de um sistema em desenvolvimențo.

\subsection{Funções de um Pacote Gráfico}

Os pacotes gráficos devem atender a uma série de diferentes funçōes agrupadas a seguir:

- Geração de elementos gráficos

- Transformações

- Funções de visualização

- Funções de segmentação

- Funções de entrada de dados

\subsubsection{Geração de Elementos Gráficos}

Um elemento gráfico é a entidade de imagem básica, tal como o ponto, o segmento de linha, o círculo e assim por diante. A coleção de elementos em um sistema inclui também caracteres alfanuméricos e símbolos.

O termo "primitiva" é geralmente utilizado para referenciar um elemento gráfico básico, porém, é comum reservar o uso deste termo para elementos gráficos tridimensionais e principalmente para sólidos como esferas, cubos, cones, etc.

\subsubsection{Transformações}

São usadas para alterar as imagens através da interface gráfica utilizada, resultando na alteração da base de dados associada. 
Transformações incluem mudança de tamanho, rotações, translações, etc.

\subsubsection{Funções de visualização}

Este conjunto de funções permite que o operador veja o projeto do ângulo que for preciso e do tamanho que for necessário para o completo entendimento do conjunto, para a implementação de detalhes, para a percepção global do projeto, etc.

A maioria dos CADs dispõe de recursos de preenchimento de superfícies, reflexão de luz, ocultamento de linhas não visíveis e outros.

\subsubsection{Eụnções de segmentação}

Os elementos do desenho do projeto, as entidades gráficas básicas, os primitivos e as entidades transformadas podem ter sempre um caráter de unicidade, que permite seu isolamento, sua seleção. Não obstante, é possível, também, agrupar conjuntos de entidades, unir primitivos sólidos e realizar uma série de operações que envolvem várias partes do desenho do projeto, gerando assim novos objetos de caráter único, que podem, ainda assim, serem particionados, retornando seus originadores.

\subsubsection{Funções de entrada de dados}

Geralmente é a forma de se iniciar um desenho, sendo fundamental simplicidade, 0 uso de referências comuns com o operador, como o uso de imagens e nomenclaturas que remetam o operador às formas mais convencionais de se desenhar. Um software que exige o dominio de linguagens de máquinas para inserir informações certamente não terá utilidade para a maioria dos projetistas. 


\subsection{Construções Geométricas}

\subsubsection{O Uso de Elementos Gráficos}

Simplifica muito $\circ$ trabalho do projetista $\circ$ uso de elementos gráficos previamente definidos. Através de seu raciocínio, o projetista irá montar conjuntos, associações e células de desenhos até conseguir representar seu projeto especifico. Assim, para formar, por exemplo, uma estrela de seis pontas, o operador poderá optar por caminhos os mais variados, sempre partindo de elementos simples e manipulando-os, como por exemplo usando dois triângulos, ou usando um hexágono e unindo seus vértices ou de inúmeras outras formas. Não importa, o que é fundamental é que o operador possa, a partir de um repertório seu, criar analogias no CAD e consiga assim seus resultados.

\subsubsection{Definindo Elementos Gráficos}

- CAD não armazena imagens, mas valores. Também não há dimensões guardadas no CAD, mas relações. Se o projeto colocado no CAD for um disco de aço com cinco centímetros de raio e um centímetro de espessura, os dados armazenados na base de dados serão uma equação de posição com um ponto de centro com relação a coordenadas prédefinidas e com medidas também proporcionais a unidades do sistema.

Esta aparente imprecisão do CAD é na verdade un de seus pontos fortes. Quando se pensa em CAD paramétrico, ou seja, onde todas as proporções relativas, é esta característica que permite o recálculo de todo o projeto em função de uma única alteração em um parâmetro. A Tabela 3 sumariza os métodos de desenho em CAD. 
Tabela 3: Métodos de definição de elementos em computadores gráficos interativos (Fontes: Notas de aulas/Manuais de Softwares).

\begin{tabular}{|c|c|}
\hline \multicolumn{2}{|l|}{ Pontos } \\
\hline 1 & Apontar com o cursor para um determinado ponto da tela \\
\hline 2 & Informar via teclado as coordenadas relativas do ponto \\
\hline 3 & Duplicar um ponto previamente definido \\
\hline 4 & Tomar a intercessão de duas linhas \\
\hline 5 & Dividir um elemento em intervalos, definindo os pontos de divisão \\
\hline \multicolumn{2}{|r|}{ 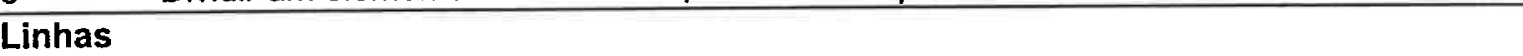 } \\
\hline 1 & Usar dois pontos previamente definidos \\
\hline 2 & Usar um ponto e indicar um ângulo em relaçăo a um linha pré-definida \\
\hline 3 & Usar um ponto e uma curva, definindo uma tangente à mesma \\
\hline 4 & Usar um ponto e fazer uma paralela ou uma perpendicular a outra linha \\
\hline 5 & Fazer a linha tangenciar duas curvas \\
\hline 6 & Fazer a linha tangenciar uma curva e ser paralela ou perpendicular a outra linha \\
\hline \multicolumn{2}{|r|}{ Arcos e Círculos } \\
\hline 1 & Especificar o centro e o raio \\
\hline 2 & Especificar o centro e um ponto do círculo \\
\hline 3 & Fazer uma curva passando por três pontos pré-definidos \\
\hline & Fazer uma curva tangente a três linhas \\
\hline & Especificar um raio e fazer a curva tangenciar duas linhas ou curvas \\
\hline \multicolumn{2}{|c|}{ Cônicas: Elipses, Parábolas, Hipérboles } \\
\hline 1 & Especificar cinco pontos no elemento \\
\hline 2 & Especificar três pontos e uma condição de tangência \\
\hline \multicolumn{2}{|r|}{$\begin{array}{l}\text { Curvas: Equações matemáticas são usadas para definir curvas através da aproximação utilizando } \\
\text { pontos marcados na mesma. O operador pode definir o tipo de aproximação desejada e o conjunto } \\
\text { de pontos existentes. Pode também escolher entre curvas que passem pelos pontos ou que os } \\
\text { aproxime da melhor maneira. }\end{array}$} \\
\hline \multicolumn{2}{|c|}{ Superfícies } \\
\hline & Utilização de superfícies de revolução de curvas em torno de um eixo \\
\hline 2 & Utilização de linhas de interseção que se unem em vértices \\
\hline
\end{tabular}

\subsubsection{Editando a Geometria}

Os sistemas CAD dispõe de capacidades de edição para fazer correções e ajustamentos no modelo geométrico. Ao desenvolver um modelo, o operador deve poder apagar, mover, copiar e rotacionar componentes do modelo. Este processo envolve (geralmente) a seleção da porção desejada do modelo e a execução do comando apropriado. 
Alguns dos comandos mais comuns de edição de softwares de CAD são mostrados a seguir na Tabela 4 .

Tabela 4: Características de edição mais comuns em CAD (Fontes:

Notas de aulas/Manuais de Softwares).

\begin{tabular}{ll}
\hline 1 & Mover um item para outra localização: isto envolve translação do item \\
2 & $\begin{array}{l}\text { Duplicação de um item existente: é uma função similar ao deslocamento, porém neste } \\
\text { caso é mantido também o item original }\end{array}$ \\
3 & $\begin{array}{l}\text { Rotacionar um item: é um movimento de rotação em torno de um eixo estipulado e com } \\
\text { um ângulo determinado }\end{array}$ \\
4 & $\begin{array}{l}\text { Espelhamento de um item: cria uma cópia espelhada (invertida) com relação a um plano } \\
\text { Apagar um item: remove o item do desenho na tela e na base de dados }\end{array}$ \\
6 & $\begin{array}{l}\text { Remoção de um item da tela: esta operação apaga o item da tela, porém o mantém na } \\
\text { base de dados. }\end{array}$ \\
7 & $\begin{array}{l}\text { Corte de um componente: esta função remove parte do elemento, situada além de um } \\
\text { determinado ponto ou curva ou superficie especificada. }\end{array}$ \\
8 & $\begin{array}{l}\text { Criação de células ou blocos de elementos: possibilita a criação de partes que podem ser } \\
\text { incluídas em qualquer projeto em diferentes posições, ângulos e dimensões. }\end{array}$ \\
9 & Mudança de escala: permite a alteração de escala em cada uma das três dimensões. \\
\hline
\end{tabular}

Além de todas as funções apontadas existe também a de desfazer uma função. Sistemas CAD mais poderosos mantém bases de dados com todas as operações realizadas desde o início da elaboração do desenho, possibilitando correções de operações feitas inadequadamente.

\subsection{Transformações}

As transformações no CAD obedecem aos princípios básicos da geometria descritiva e da álgebra, envolvendo equações de translação, escala, rotação, concatenação e outras. 


\subsection{Estrutura e Conteúdo da Base de Dados}

Sendo o principal meio de troca de informações entre várias sistemas que interagem em uma indústria lou em várias indústrias correlatas), a base de dados torna-se fundamental em qualquer aplicação, e em sistemas CAD não é diferente.

Os dados bem estruturados de um sistema o definem como forte $e$ consistente ou não. Se o CAD gerar ilustrações muito bonitas, porém for deficiente em sua base de dados de nada adiantará. Este é o caso da arte, onde todo o esforço da técnica se volta para um resultado único, porém brilhante. Na engenharia, e nos negócios em geral, a reprodutibilidade é uma peça chave. Se os dados são confiáveis em um sistema CAD, é possivel tirar proveito deles em inúmeras situações, como por exemplo, transformando-os em coordenadas para sistemas CAM ou para a operação de processos.

Genericamente, os dados a serem armazenados são:

- Elementos gráficos básicos (pontos, linhas, etc.);

- Geometria (forma) dos componentes do modelo e sua organização no espaço;

- Topologia ou estrutura dos modelos, ou seja, como os vários elementos se inter-relacionam;

- Dados específicos de aplicações como por exemplo propriedades do material de que é composto o modelo;

- Dados específicos de aplicações de análise tais como programas de análise de elementos finitos. 


\subsection{Estrutura em Arame (Wire-Frame) e Modelagem Sólida}

\subsubsection{A Importância da Geometria Tridimensional}

Os primeiros sistemas CAD dispunham apenas de recursos de duas dimensões, apenas automatizando o método de desenho em pranchetas. Entretanto, como os desenhos eram (e são) representações de objetos com três dimensões, era preciso lançar mão de recursos de representação como cortes, vistas, perspectivas, etc. para que o objeto pudesse ser compreendido inteiramente.

O advento do CAD com três dimensões trouxe não só uma aproximação muito maior da representação do objeto com o próprio objeto, mas, principalmente, uma mudança na forma de projetar convencional.

Em CADs 3D o projetista trabalha em um único modelo com todas as informações agregadas, não sendo mais necessário transferir medidas e ângulos nem correr 0 risco de desenhar vistas impossiveis ou inadequadas.

\subsection{Modelos em Arame (Wire-Frame)}

Hoje em dia, os CADs mais comuns e simples usam uma forma de modelagem chamada de "Wire-Frame". Neste tipo de modelagem, os eixos dos objetos são representados como linhas, ou seja, não há representação de superfícies, mas de encontro de superfícies planas. 


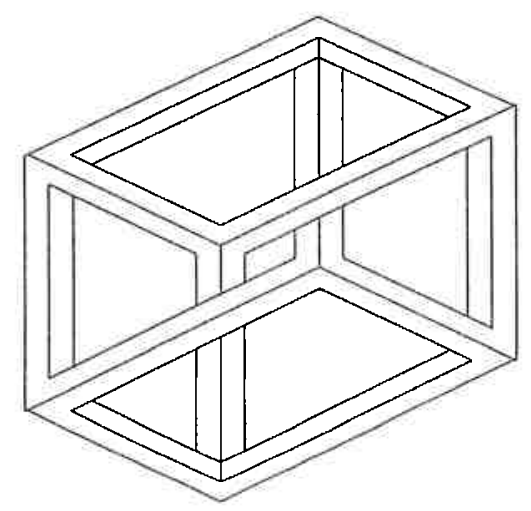

\section{Figura 9: Objeto sem sentido físico (Notas de aulas).}

No caso de superfícies curvas, portanto, a representação é feita por gomos, ficando uma esfera, por exemplo, representada como um poliedro de muitas faces.

Esta representação apresenta também o problema de dificultar o reconhecimento de partes visiveis ou invisiveis, uma vez que as linhas são todas visíveis. Observadores mais incautos podem tomar uma representação como a vista na Figura 9 como sendo uma forma possível, a menos que o software disponha de recursos de ocultamento de linhas escondidas.

\subsubsection{Modelos Sólidos}

A modelagem sólida tem se tornado padrão na indústria, pois é mais completa, muito mais clara e consistente. Os modelos gerados não apenas são visualizados muito melhor pelo operador, podendo assim serem corrigidos em suas falhas, mas também são checados pelo próprio sistema, que aponta sobreposições, vãos indevidos ou formas infactiveis, e, em função de parâmetros de projeto, previamente programados, evita perdas de tempo na busca de soluções que jamais serão alcançadas. 
Duas formas básicas de desenvolvimento de modelos sólidos são bastante utilizadas por softwares comerciais: geometria de sólidos construtivos (CSG ou C-rep), também chamada de método de construção por blocos e representação por fronteiras (B-rep)

O método CSG permite que o operador construa seu modelo a partir do uso de primitivas sólidas tais como cubos, esferas, cilindros, pirâmides, etc. Através de operações boleanas, estas primitivas são combinadas (somadas, subtraidas, etc.) formando o sólido desejado.

A representação B-rep já exige um pouco mais de habilidade do operador, que terá que construir inicialmente um modelo como linhas (fronteiras) e depois promover operações sobre estas. O método B-rep tem a vantagem de gerar sólidos mais complexos com maior facilidade, porém para sólidos mais simples, o método CSG torna-se mais vantajoso.

\subsection{Importação e Exportação de Desenhos}

Devido ao grande e crescente número de sistemas CAD disponíveis no mercado, surge o problema da falta de padronização das bases de dados armazenadas. Via de regra, o conteúdo de um projeto pode ser sintetizado em formatos de arquivos, gerados em módulos de exportação ou simplesmente armazenando-o em uma mídia qualquer.

Quando surge a necessidade de um projeto ser desenvolvido ou simplesmente armazenado em vários ambientes diferentes é preciso, muitas vezes converter os dados para que eles possam ser interpretados.

É comum, por exemplo, que áreas de projeto possuam sistemas mais possantes $e$, consequentemente, mais caros. Isto não é necessário, 
por exemplo, em uma área de compras, que precisa, no entanto, ter acesso às informações do projeto. Nesta área, os equipamentos são mais simples e os sistemas por eles suportados, mais modestos.

Para que ambos possam trocar informações, o sistema da área de projetos deve gerar dados que possam ser lidos pelo da área de compras e vice-versa.

Pela diferença na amplitude da necessidade de cada um, fica evidente que não é possível fazer conversões que preservem todo o conteúdo de ambas as partes. Algumas características serão perdidas.

Não se pode dizer que $\circ$ ideal seria que todos os sistemas utilizassem o mesmo padrão. Isto inviabilizaria avanços em função de novas tecnologias que surgem, porém, um padrão mínimo é desejável, mesmo que ele não contemple todos os recursos de determinados CADs.

Genericamente, há duas formas de se fazer a comunicação entre tipos diferentes de CAD: ou através de um conversor simples (Figura 10) ou através de um padrão comum intermediário (Figura 11).

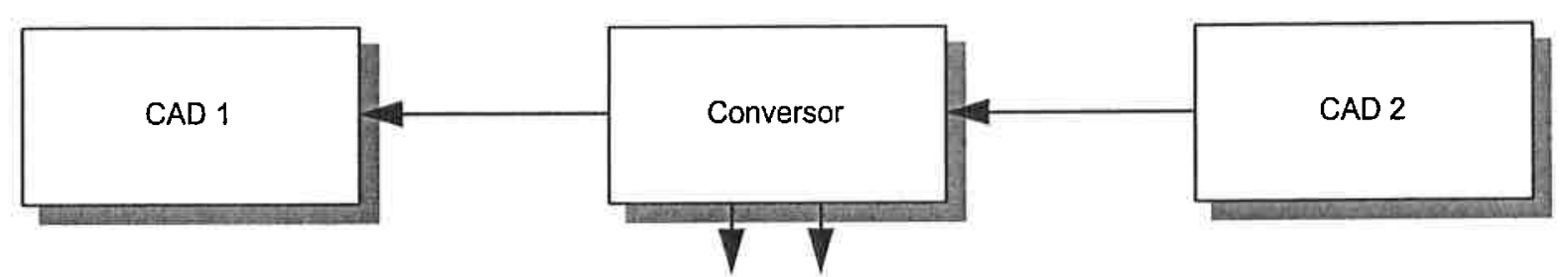

Figura 10: Conversão direta entre dois tipos de CAD 


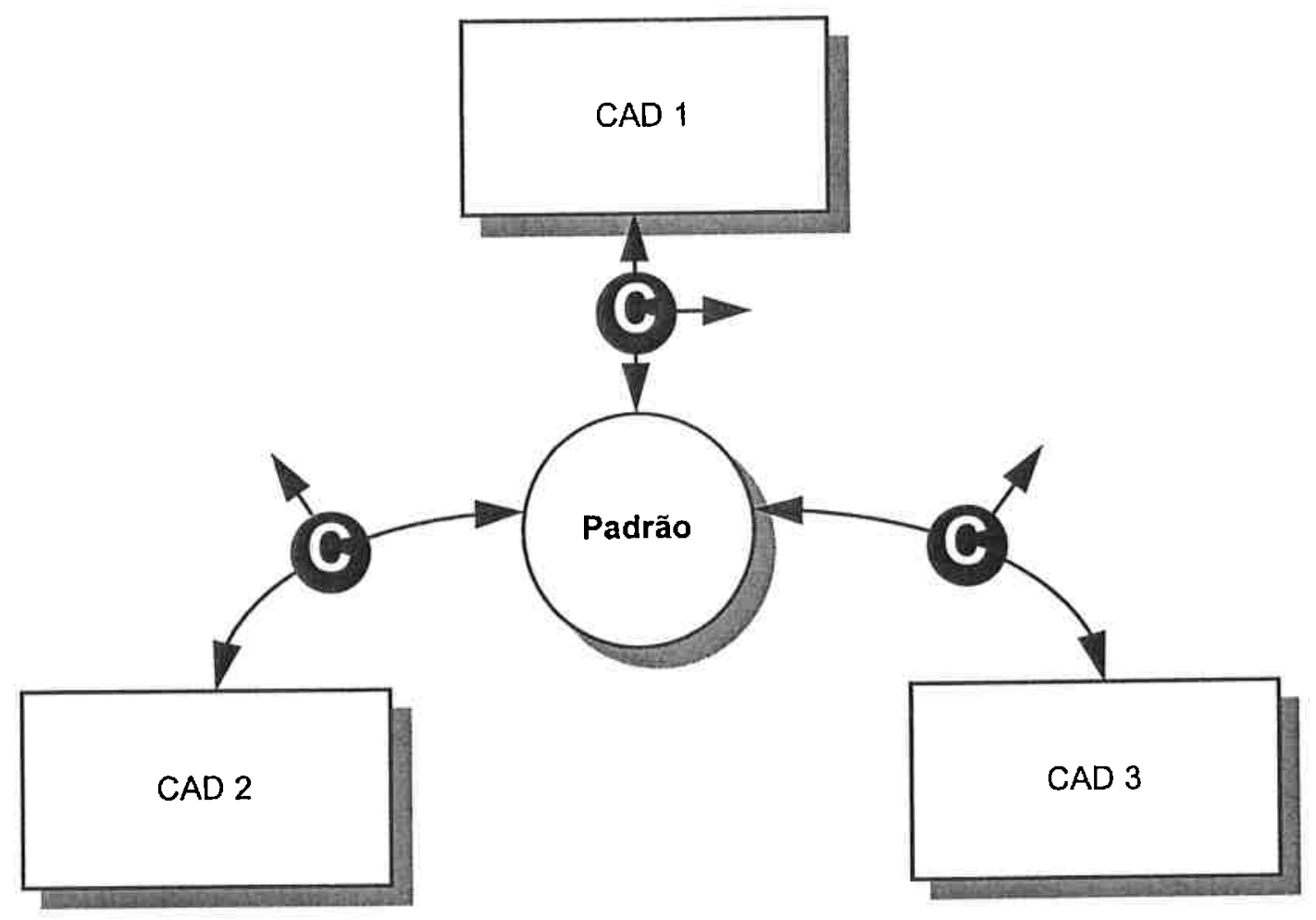

Figura 11: Conversão com uso de padrão intermediário.

o primeiro caso, a conversão direta, exige um software conversor para um primeiro tipo de $C A D$ que gera um formato interpretado para - segundo CAD. A vantagem desta opção é que os dados convertidos guardam, geralmente, grande parte do conteúdo do CAD que os originou. A desvantagem é que quando há mudanças de versão no CAD originador ou no interpretador (e elas sempre ocorrem) é preciso mudar a versão do conversor também.

o segundo caso, a conversão para um padrão intermediário, é mais utilizada em softwares comerciais e tem a vantagem de oferecer um comportamento próximo ao neutro com relação a possiveis atualizações de versão dos CADs envolvidos na troca de informações. Por outro lado, fica evidente que a perda de informações no processo de conversão pode ser bastante grande. 
Durante muito tempo tentou-se definir um padrão para trocas entre CADs, chegando-se a formatos do tipo IGES (predominantemente gráfico) ou EXPRESS (com informações também sobre materiais e outras características). No mercado de microcomputadores, tornouse popular o Autocad e seus formatos DWG ou DXF e DXB, porém, nenhum deles é totalmente aderente e nem poderia ser.

Quanto mais poderoso o CAD e maior sua capacidade de manipulação de bancos de dados realmente consistentes, maior a capacidade de preservação de informações. Não se pode tentar igualar os formatos pelo minimo de mercado, mas deixar folgas nos padrões neutros para que eles alcancem a amplitude dos softwares mais poderosos.

\subsection{Conclusão}

Um projeto completo envolve não apenas capacidade de desenho, tão pouco apenas poder criativo e sequer capacidade de aproveitamento de conhecimentos passados.

Um projeto completo envolve uma visão de futuro com raizes em experiências passadas, com colaborações de culturas diferentes, com "luzes" de horizontes mais longínquos. Não basta ter o melhor equipamento se as equipes não estiverem comprometidas, treinadas, aguçadas.

- CAD por sí só não é uma panacéia, uma solução simples que se implanta em algumas semanas, e é isto que cada vez mais as empresas têm percebido, voltando seus esforços para a integração de técnicas que durante muito tempo estiveram isoladas. A análise dos processos industriais tem mostrado que a quantidade de informações dispersas pela empresa tem um custo muito elevado para ser desperdiçada. Quando a informação não está organizada, 
concentrada, ela se dissipa, se perde, causa ruídos internos e prejudica muito o andamento dos negócios.

Portanto, não basta conhecer CAD, CAM, CIM, marketing, processos de produção, logística, etc. É preciso saber integrar ferramentas, fazê-las interagir, compreender cada uma delas em seu papel no conjunto de recursos de que a empresa dispõe. 


\section{Dados e Informações dentro da Empresa}

\section{1 "Data warehousing"}

O uso deste termo em inglês tem se tornado corrente nas empresas. $\mathrm{Na}$ tradução literal, significa repositório de dados, porém, este significado diz pouco a respeito do que realmente é o "Data warehousing" (as aspas serão omitidas daqui para frente, pois o termo é usado no Brasil sem tradução).

Segundo GUPTA (1997), o uso do data warehousing transformou-se em uma prática comum e popularizou nas empresas. Os primeiros a terem construido data warehouses consideraram seus sistemas corporativos e transacionais como sendo componentes chaves da estruturação dos repositórios.

o data warehouse manipula os dados operacionais (transacionais ou não) fora dos mesmos, ou seja, existe todo um aparato que resguarda a integridade dos dados operacionais, enquanto os mesmos podem ser tratados de diferentes formas, gerando informação útil para diversas áreas da empresa.

\subsection{Abordagem convencional dos dados.}

Os sistemas convencionais (ou transacionais) sempre enfatizam a parte operacional da empresa e os dados envolvidos nos processos corriqueiros. A armazenagem indefinida de dados neste tipo de sistema não é prática, uma vez que o principal requisito é o alto desempenho em termos de velocidade de processamento e confiança nas transações efetuadas. Ainda hoje, com os recursos disponíveis 
em uma empresa de alto nível tecnológico, não é fácil conciliar performance e grandes volumes ${ }^{13}$.

Segundo GUPTA (ibidem), nos anos 70, a maioria dos sistemas eram desenvolvidos em computadores de grande porte ("Mainframes"), usando ferramentas como Cobol, CICS, IMS, DB2 e outras. Nos anos 80, utilizava-se muito plataformas do tipo "minicomputadores" como - AS/400 e O VAX/VMS. No final dos anos 80 e início dos anos 90, popularizou-se $\circ$ servidor UNIX, introduzindo-se a plataforma cliente/servidor.

Ainda hoje, especialmente no Brasil, é comum vermos aplicações das mais diversas operando em todos estes tipos de ambientes, por motivos que vão desde falta de recursos para atualizações até a justificativa técnica de que absolutamente não se torna necessário substituir um sistema antigo mas que atende plenamente as necessidades do negócio ${ }^{14}$.

13 Grandes volumes não são os dados processados por uma loja ou por uma fábrica de componentes mecânicos, mas, por exemplo, as transações realizadas diariamente por um banco de abrangência nacional em um país como o Brasil. Há aplicativos que suportam normalmente milhões de transações diárias.

$14 \mathrm{Na}$ verdade, não tem sido as necessidades de negócio as definidoras das tecnologias utilizadas, mas as imposições do mercado, que muitas vezes não oferece pessoal habilitado para dar manutenção aos antigos sistemas e equipamentos. 


\subsection{Recuperação de dados de sistemas legados}

Estes antigos sistemas, chamados de sistemas legados, armazenam dados muitas vezes vitais para a empresa, e, em função de sua arquitetura restrita, somente disponibilizam os dados por meio de arcaicos relatórios impressos ou no máximo através de arquivos de dificil conversão para softwares mais modernos.

o profissional de sistemas, tornou-se, portanto um poderoso detentor das informações da empresa, uma vez que ele pode definir como emitir um relatório e quando disponibilizá-lo. Para os interesses da empresa esta situação é muito desconfortável, sendo fundamental designar formas de tornar os dados mais facilmente acessíveis.

\subsection{DSS e EIS ("Decision-Support System" e "Executive Information Systems") - Sistema de Suporte à decisão e Sistema de Informação Executiva}

Primordialmente, o propósito do data warehousing são $\circ$ DSS e o EIS.

- DSS prioriza os detalhes e é direcionado aos gerentes de níveis médio e baixo, que lidam com muitos dados operacionais da empresa, enquanto o EIS fornece informação consolidada e visões multidimensionais e destina-se a altos niveis de gerência. Esta distinção conceitual é meramente formal, uma vez que operacionalmente tem-se apenas um único sistema e dentro deste, através de níveis de segurança, os dados são ou não disponibilizados.

Algumas características destes sistemas são: 
Os dados armazenados nestes sistemas tem formato descritivo e em padrões estabelecidos pelas áreas de negócio ao invés de campos e códigos:

Os dados são geralmente pré-processados para serem adequados às necessidades das visões de negócio;

Visões consolidadas por critérios como produto, cliente, períodos e outros são disponibilizadas.

Segundo GUPTA (1997), fatores importantes na viabilização do data warehousing são:

- Redução progressiva dos preços dos equipamentos de informática;

- Aumento significativo da performance dos equipamentos do tipo "desktop";

- Aumento significativo da performance dos servidores de softwares;

- Explosão do uso de Intranets e aplicações baseadas em aplicativos Web.

Ainda acrescenta-se a esta lista o uso generalizado de pacotes de gestão empresarial unificados que centralizam os dados operacional facilitando sua captura e manuseio. 


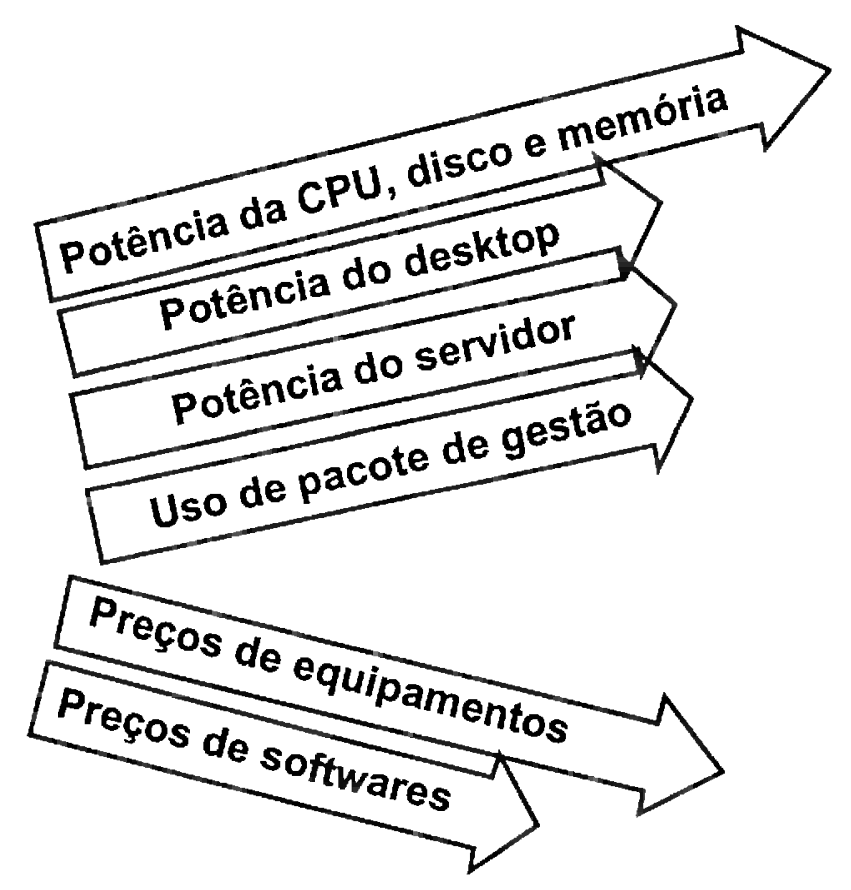

Figura 12: Impacto da revolução tecnológica ladaptado de GUPTA (1997))

\subsection{Requisitos do negócio}

É claro, porém que, ainda que tenha havido toda a criação de um ambiente tecnológico que propiciasse a formação do data warehousing, o motor do surgimento do data warehousing foram os requisitos de negócios das empresas, impulsionados por mudanças profundas advindas de:

Fatores econômicos dos últimos anos: esta época marcada por inúmeras crises internacionais ocasionou fenômenos como a "reengenharia de processos" e o "downsizing", forçando uma reanálise profunda das práticas de negócio.

Globalização: a derrocada do comunismo e a liberalização das economias asiáticas e latino americanas abriram espaço para que 
empresas investissem em mercados novos e desconhecidos, causando um crescimento muitas vezes inesperado e de dificil gerenciamento.

Perfil do empregado: com a massiva popularização tecnológica, os requisitos de perfil de um empregado mudaram muito, possibilitando novos saltos tecnológicos que podem trazer benefícios ao negócio.

Maior uso de informação: cada vez mais a informação que antes se restringia a altos niveis gerenciais torna-se importante a baixos níveis de gerência, dando uma visão mais completa do cenário no qual estes profissionais atuam e guiando a trajetória dos mesmos.

\subsubsection{Integração dos dados da empresa:}

Por ser uma entidade "autônoma"15, o "Data warehouse" não se restringe a áreas da empresa, mas, ao contrário, ele agrega dados de tantas áreas quantas forem possiveis, desde que os requisitos de negócio demonstrem necessário. Assim, dados de áreas de vendas, marketing, finanças e produção podem ser relacionadas, trazendo indicadores de difícil captura quando estas áreas se encontram em sistemas distintos.

Não há nos textos citados, e também não tenho notícia de casos práticos que incluam no data warehouse, dados de áreas de projeto. Normalmente é criado um sub conjunto do data warehouse que contempla estes dados, porém sem relacioná-los com os dados de outras áreas. Mais adiante tentarei explicitar algumas razões de por que isto ocorre.

15 Apesar de extremamente dependente dos sistemas operacionais transacionais, o "Data warehouse" tem existência fisica independente, ainda que sem sentido prático. 


\section{6 o funcionamento do data warehouse}

Na maioria dos sistemas de EIS ou DSS, as consultas e relatórios são pré-definidas por analistas de negócios das áreas interessadas, porém, é difícil prever o grau de utilização sob o qual estará sujeito o "Data warehouse", pois os sistemas atuais permitem consultas livres, ocasionando por vezes transações de grandes volumes no banco de dados. Alguns produtos utilizam o datawarehouse como uma camada intermediária, gerando novos repositórios ${ }^{16}$ que são mais facilmente utilizados pelo usuário final.

Uma caracteristica importante do data warehouse é a não volatilidade dos dados, ou seja, deve haver critérios para que os dados sejam disponibilizados no "Data warehouse", pois uma vez lá, eles não podem ser alterados ${ }^{17}$.

16 Um conceito que vern sendo utilizado é o do cubo ou o da base multidimensional, que copia dados do "Data warehouse" já em um formato mais próximo daquele desejado pelo usuário final e disponibiliza esta base ou em um servidor ou na própria máquina do usuário.

17 É interessante notar como isto pode determinar diferenças de avaliação. Por exemplo, uma empresa faz uma série de vendas a longo prazo, com entrega para um ou dois meses depois do pagamento. Este tipo de operação pode gerar um falso resultado de vendas, uma vez que os pedidos podem ser cancelados futuramente. 0 data warehouse não deve conter os dados destas vendas enquanto elas não estiverem de fato concretizadas, ou seja, o produto entregue e a fatura paga (pelo menos parcialmente), a menos que 
Outra característica é o período abrangido pelo data warehouse. Este fator depende muito do tipo de negócio (ver a respeito no Capitulo Definições Gerais, página 24).

Na Figura 13 estão sintetizados alguns critérios de formação de um "Data warehouse".

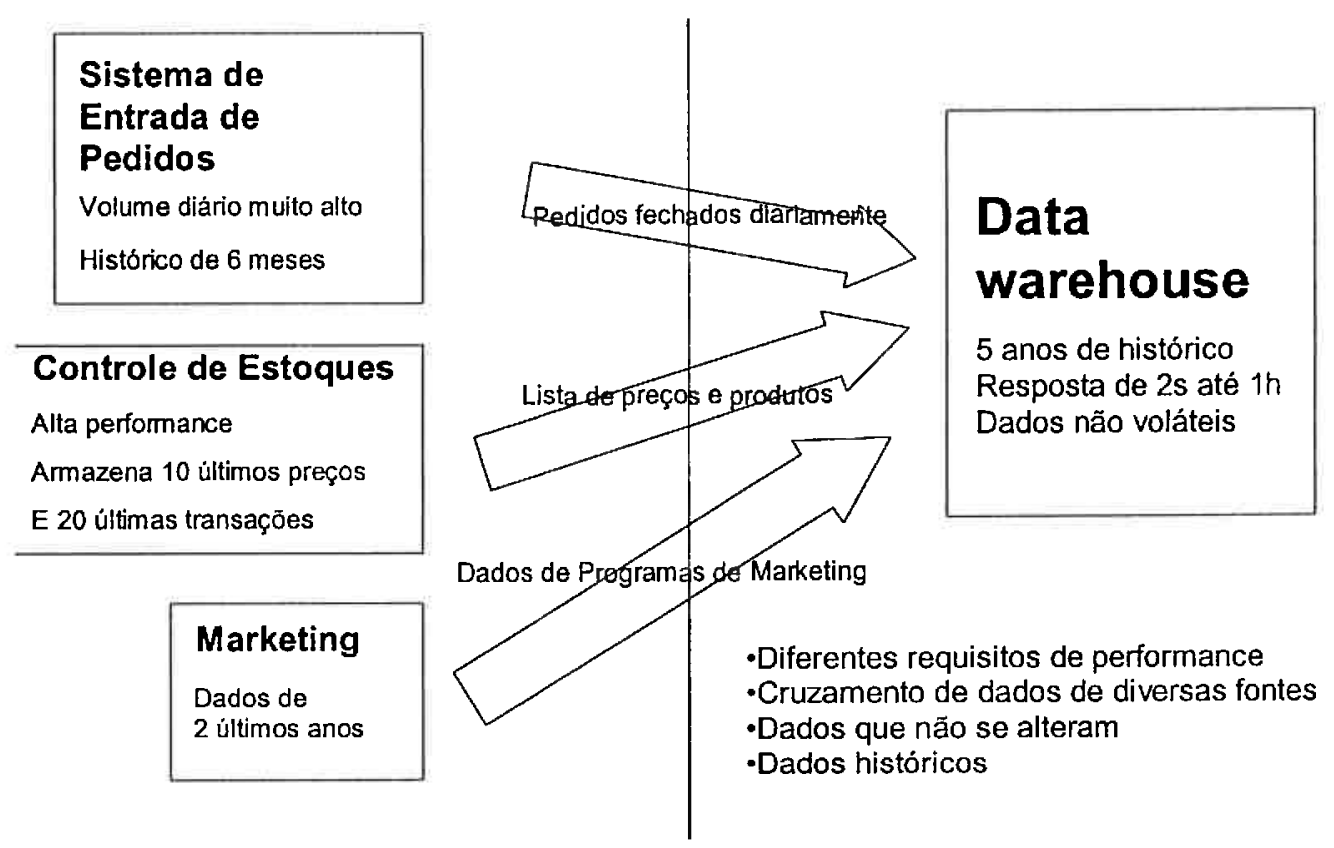

Figura 13: Critérios de formação de um "Data warehouse" (adaptado de GUPTA (1997)).

De acordo com os conceitos de modelagem de dados, o data warehouse tem uma estrutura desnormalizada ${ }^{18}$, diferentemente dos bancos de

ele contemple operações de cancelamento, porém, isto já sai fora do escôpo de um sistema EIS ou DSS.

18 A modelagem normalizada é baseada na estruturação dos dados por critérios de objetos, onde cada dado tem identidade própria e distinta. A modelagem desnormalizada força a redundância de 
dados transacionais, isto porque a informação armazenada tem um caráter mais completo, já sendo um resultado do cruzamento de vários dados. Justifica-se isto pelo fato de o "Data warehouse" refletir um modelo de negócio e não um processo isolado (ver Capítulo Dados e Informações dentro da Empresa página 79).

algumas informações para facilitar consultas específicas. Há 3 níveis de normalização descritos a seguir:

- Normalização primária: descreve cada entidade unicamente e sem nenhum tipo de repetição;

- Normalização secundária: quando em qualquer relação entre diferentes entidades houver apenas chaves primárias e

- Normalização terciária: quando qualquer atributo não chave em uma entidade é completamente independente de qualquer outro.

o processo de normalização geralmente quebra a tabela em inúmeras outras tabelas independentes. Se por um lado, um banco de dados normalizado é extremamente flexível e fiel ao modelo real, por outro lado, tem uma performance que muitas vezes deixa a desejar e é de dificil interpretação pela sua alta complexidade. 


\section{Aspectos Gerais de Interfaceamento}

Vários aspectos são relevantes na busca da correta troca de informações, dentre os quais cita-se os seguintes:

Como se dá o fluxo de informações desde o chão de fábrica até as esferas de poder decisório, e como esta informação se traduz em informação efetiva de projeto;

Como são encarados processos cada vez mais automatizados, que dispensam em muito a interferência de operários ou mesmo de profissionais bastante capacitados e como estas pessoas podem ou querem colaborar na dinamização dos processos de trocas de informações.

Como se efetua o interfaceamento de dados entre empresas ou departamentos do tipo cliente/fornecedor, principalmente no que tange a projetos de produtos;

Quais os impactos de plataformas e protocolos tão diversos como uma máquina CNC e um coletor do tipo "Handheld".

Cada um destes tópicos pode muito bem ser estendido indefinidamente, sendo impossivel esgotá-los em um trabalho como este.

SERVA (1992) coloca que "o conceito de organização está correlacionado às idéias de sistema e de ordem. A organização é a produtora de um sistema ou uma unidade complexa, pois se afirma como disposição relacional que liga, transforma, mantém ou produz componentes, individuos ou acontecimentos. Ela garante solidariedade e solidez relativa às ligações, criando possibilidades de duração ao sistema, em face das perturbações aleatórias." 
MORGAN (citado por SERVA(1992)) demonstra as vantagens auferidas com o emprego de modelos circulares de interação para conceber as relações organização-ambiente.

Revendo as teorias sobre a gestão da mudança organizacional, Morgan detecta que elas ou são puramente descritivas ou caracterizam a mudança com termos abstratos, tais como incerteza e instabilidade. Essas teorias permitem elaborar alternativas de como a organização pode reagir diante de diferentes tipos de mudança ambiental.

A profunda complexidade presente no âmbito das interações partetodo num sistema organizacional dado não é devidamente abordada pela teoria das organizações, talvez por questões ideológicas. É inegável a preponderância da idéia do todo sobre as partes da organização, no paradigma funcionalista, o qual guia a teoria organizacional tradicional.

Segundo SPINK (também citado por SERVA(1992)), "O todo é menos que a soma das partes (porque estas, sob o efeito das coações resultantes da organização do todo, perdem ou vêem inibir-se algumas de suas qualidades ou propriedades); a consciência-de-sí só emerge nos individuos. Neste sentido: as partes são eventualmente mais que o todo..."

Já a visão sistêmica, ou de sistemas propriamente dita, considera que o todo é maior que a soma das partes individuais, numa referência clara à sinergia gerada pela interação entre partes. Tais interações só se concretizam positivamente se houver o correto interfaceamento e o entendimento mútuo e amplo entre as várias partes.

No mesmo texto, o autor associa a idéia de evento ou acontecimento ao acaso, afirmando que o paradigma da complexidade afasta-se do determinismo que sempre predominou na ciência clássica. Segundo 
esta ótica, sistemas de informações devem buscar uma abertura que sobrepuja a especificação simplista e abrace definições mais genéricas e conceituais, passando por componentes de lógica fusa e inteligência artificial em sistemas neurais, ou seja, tentando aproximar-se o mais possível da forma de funcionamento do cérebro humano.

A união de vários sistemas de informação, levando em conta, inclusive, o relacionamento dos operadores deste tipo de sistema com o novo paradigma da automação decisória, mostra o quão abrangente pode ser a análise necessária para se atingir questões centrais na estrutura desta interação.

Sistemas de informação armazenam dados provenientes não só das linhas de produção (tanto manufatureira quanto de serviços) mas também de sistemas contábeis, de áreas de mercado, de recursos humanos, de projetos, externas e tantos outros, e organizam estes dados de forma a traduzi-los aos niveis decisórios eficazmente. Entenda-se aqui, nível decisório como sendo qualquer nivel onde pessoas recebem informações, as interpretam e as transferem em forma de ação ou recomendação.

SALERNO (1994) cita uma exemplo de operadores de uma máquina CNC onde ocorria um problema na programação da máquina. Pelo exposto, os operadores tinham capacitação técnica para resolver o problema, porém, por uma impossibilidade de maior interação com o equipamento, a solução do problema teve que ser postergada até o momento em que o programador pode verificá-lo. Sistemas que comportam uma maior interação poderiam contornar tais situações através de por exemplo uma lista de possíveis procedimentos aceitáveis disponível aos operadores da máquina CNC (uma espécie de "helpdesk"), ou através do contato "real time" com os detentores do poder decisório. 
Quanto ao relacionamento das pessoas com esta nova realidade, algumas situações reais têm sido estudadas nos últimos anos, porém, a grande mudança, e em uma escala abrangente, ainda está por vir.

MARX (1992) cita o exemplo de Kalmar para descrever a experiência de Grupos Semi-Autônomos (GSAs) naquela montadora da Volvo. No caso descrito, os trabalhadores se defrontam com novas situações como:

Substituição da estratégia de economia de escala pela economia de escopo ou forma;

- Uso intensivo de microeletrônica;

- Uso crescente do trabalhador como recurso "inteligente";

- Terceirização e foco no negócio;

- Reuniões de empresas em redes.

Que relacionam-se diretamente com o implemento da comunicação inter. e extra empresa. A coleta de dados torna-se fundamental e será tanto mais eficiente quanto mais comprometidos e esclarecidos estiverem os niveis operacionais. Em principio, os GSAs propiciam um ambiente favorável ao melhor entendimento de suas responsabilidades, ainda que nada garanta que isto aumente 0 entendimento de cada um dos objetivos corporativos.

Assim, deve-se dimensionar o nível de informações obtidas à abrangência do entendimento dentro do grupo ou dentro da empresa de maneira geral. Pode-se identificar "graus" de informação, como por exemplo, informações para projetos, para planejamento de produção, para logística, para planejamento de vendas, para planejamento estratégico corporativo, etc. 
Isto não significa que as divisões ou os grupos de trabalho geram compartimentos isolados de informações, mas, ao contrário, faz com que aquelas informações pertinentes ao escopo do trabalho de cada um cheguem mais rápido e mais precisamente ao seu destino. Isto também não quer dizer que, por exemplo, um administrador de recursos humanos não poderá ver os dados referentes ao projeto de um produto no departamento de projetos, mas ele os verá da forma como ele (administrador de recursos humanos) é capaz de entendêlos ou como lhe interessa.

De qualquer forma, o que se tem visto no relacionamento trabalhador/máquina é o padrão normal do que sempre ocorreu em mudanças de paradigmas, ou seja, o paradoxo do aceitar negando os benefícios. Estas novas mudanças são cercadas por um "medo" e por uma insegurança pessoal perfeitamente aceitável para um ser cuja complexidade desafia a ciência.

o novo conceito de trabalho que vem se traduzindo cada vez mais no não emprego (pelo menos da forma como o conhecemos) é apoiado nas comunicações e trocas de dados otimizadas. O trabalho virtual ou a empresa virtual são conceitos totalmente dependentes da informação automatizada. O que antes parecia inviável por custos elevados e por tempos altíssimos hoje traduz-se em uma palavra conhecida por crianças de jardim da infâcia: INTERNET...

A junção e o relacionamento de universos tão díspares que cobrem do Japão ao Brasil, passando por lugares ermos e por megalópolis parece, à primeira vista, absurda. Não se pode unir dados de um hábil manipulador de um "sorubá" na Malásia com a informação de um medidor de abalos sísmicos no polo sul, e nem é este o intuito de sistemas de informação, porém, o entendimento de diferentes protocolos de comunicação, de diversas formas de armazenagem "magnética" de dados e de sistemas operacionais distintos tem se tornado um desafio àqueles que antes disseminaram indiscriminadamente tais plataformas. A ânsia de ganhar mercados 
(um mercado emergente) fez com que fabricantes, analistas e projetistas lançassem seguidamente produtos, cada um prometendo ser o melhor, porém nenhum oferecendo soluções realmente integradoras.

Existem hoje no mercado produtos específicos para EIS de que se dizem "multi-plataforma", alguns vêem bancos de dados diferentes e funcionam sob sistemas operacionais em PCs e em Mainframes; comunicam-se por X400, por Internet, por correio eletrônico ou por cabos telefônicos diretamente. Mas, mesmo que seja possivel uma solução que se encaixe em qualquer configuração técnica, não se tem garantia alguma de que as informações trocadas são úteis, ou pior, de que elas não são prejudiciais.

As organizações precisam passar por um processo de "auto-análise" que se reverte num conhecimento não só de seus processos como pregava a reengenharia, mas fundamentalmente de suas estruturas de dados, ou seja, aquilo que há de concreto (mesmo que se esteja falando de empresas virtuais) e de seus relacionamentos com o ambiente que a cerca.

Não há dúvidas de que empresas envoltas pelo paradigma vigente nas últimas décadas não vê com bons olhos a troca de alguns tipos de dados com seus fornecedores ou mesmo com parceiros, muito menos com concorrentes seus. Aos poucos, porém, percebe-se que a agilidade gerada por estas trocas sobrepõem o que muitas vezes se encara como "segredos" organizacionais, mesmo porque, informações confidenciais são perseguidas incansavelmente por espiões industriais que sabem muito bem quais são suas fontes.

o "auto-conhecimento", assim como no caso dos seres humanos, vem se tornando também para a empresa, uma opção de sabedoria, pois permite a abordagem e resolução de forma mais rápida e simples não só de problemas de comunicação mas de muitos outros tipos de problemas estruturais. 


\subsection{Análise do Universo de Dados Corporativos}

Um ponto de partida para o correto interfaceamento e a troca de informações é a análise da empresa como um todo.

LAUDON; LAUDON (1994) cita duas metodologias principais para estabelecer os requisitos essenciais de informações da organização, que seriam: a análise da empresa como um todo e a análise dos fatores criticos do sucesso:

\subsubsection{Análise da empresa como um todo}

Prega que as necessidades de informação podem ser compreendidas através da visualização da empresa como um todo em termos de suas unidades, funções, processos e dados. Esta análise pode ajudar a identificar as entidades e atributos chave dos dados organizacionais. O método começa com a noção de que os requisitos de informação de uma firma ou divisão só pode ser adquirida através do estudo da organização como um todo. O método foi desenvolvido pela IBM nos anos 60 e tem, hoje em dia, um caráter mais histórico do que prático.

Convoca-se uma grande parcela de gexentes para saber deles como utilizam as informações, onde eles as conseguem, como é o meio ambiente no qual eles atuam, quais seus objetivos, como eles tomam as decisões e quais suas necessidades de dados.

Com os dados obtidos, monta-se matrizes de apoio.

A matriz de processos versus organizações identifica as pessoas que participam de processos especificos tais como planejamento, projeto e produção. A matriz de processos versus classes de dados destaca quais informações são necessárias no desempenho de 
processo em particular, quais processos geram dados e quais os utilizam. Desta forma, pode-se identificar grupos de dados que concorrem para o desempenho de um conjunto de processos:

A matriz Processos/organização identifica as pessoas na organização que participam de processos especificos tais como planejamento, administração, etc. Já a matriz Processos/Dados, explicita quais informações são necessárias para sustentar um processo particular, quais processos geram dados e informações e quais consomem. Pode-se identificar, então, grupos lógicos de aplicações, ou seja, grupos de dados que sustentam um conjunto de processos organizacionais correlatos.

Por se tratar de um método "botton-up", mostra de forma detalhada e as vezes redundante como surge e como é usada a informação na organização.

Este método, incontestavelmente, gera muito material para ser analisado, não oferecendo facilidades de visualização de um contexto mais global do que é realmente a empresa. Torna-se dificil e cara sua utilização, implicando em demora até se conseguir os primeiros resultados. Em contrapartida, uma vez compreendido, dá uma visão detalhada da empresa.

\subsubsection{Análise dos Fatores Críticos do Sucesso (FCSs)}

Baseado no modelo de PORTER (1991) e nas propostas de Rockart descritas por IAUDON; LAUDON (1994), este método diverge frontalmente do anterior. Pressupõe-se que os requisitos de informações são definidos por um pequeno número de FCSs da gerência.

FCSs definem metas organizacionais que, se seguidas (perseguidas), asseguram, segundo Rockart, o sucesso da organização. 
Os FCSs são moldados pela indústria, pela empresa, pelos gerentes e pelo ambiente de forma geral. Trata-se pois de uma técnica estratégica, e, uma das premissas fundamentais é que se limite o número de FCSs para que o sistema de informações seja o mais focado possivel nos reais interesses corporativos.

Operacionalmente, também se dá por entrevistas, porém em um nível de alta gerência, identificando as metas individuais e os FCSs na visão de cada um. Através da agregação consensual dos FCSs individuais, determina-se os FCSs corporativos, e o sistema de informações contemplará estes FCSs.

A seguir, mostra-se graficamente o modo como se desenvolve este método: 


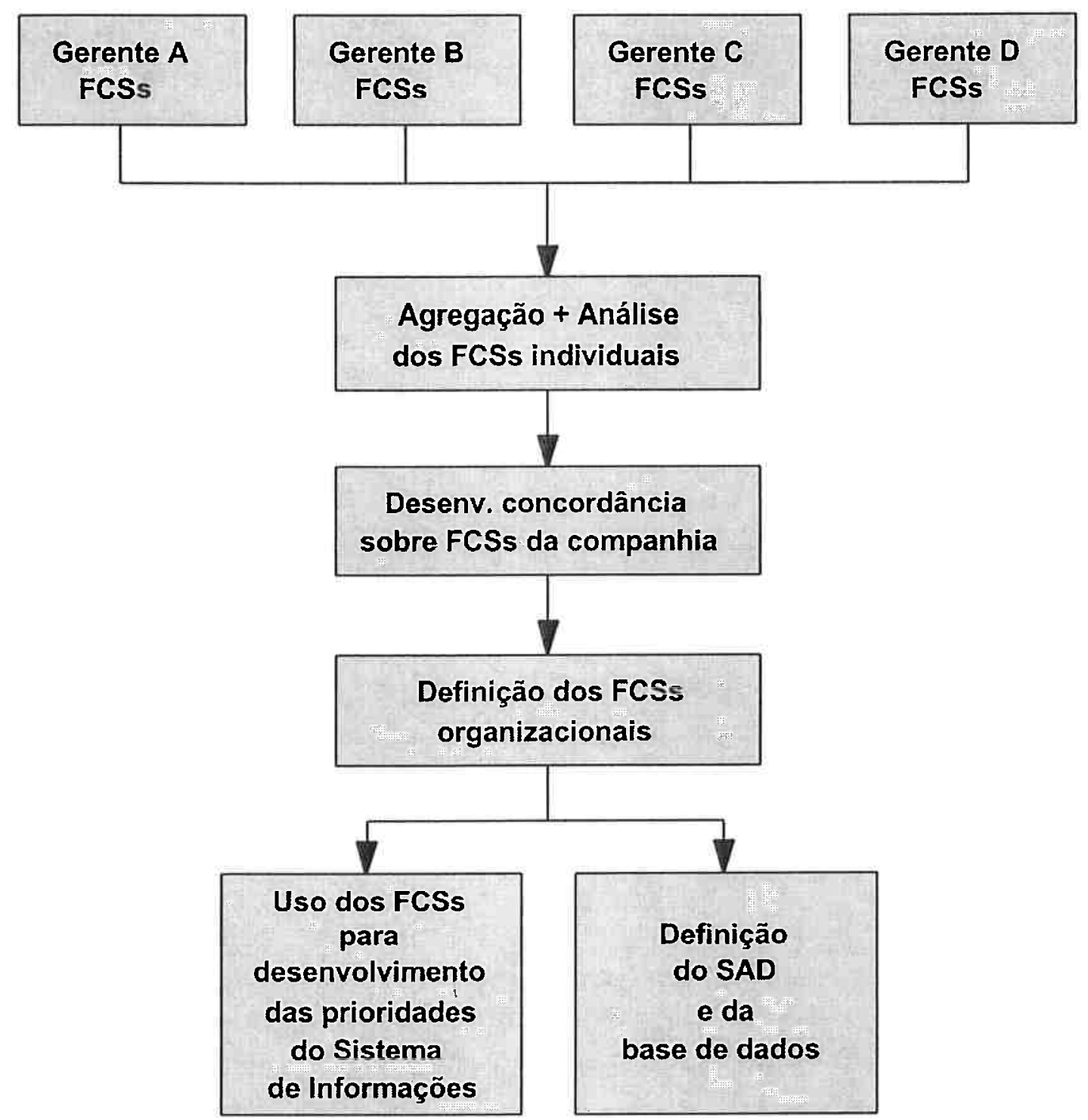

Figura 14: Fluxograma do método de análise dos FCSs. (LAUDON; LAUDON (1994)).

A grande vantagem do método, segundo uma visão mais contemporânea do planejamento estratégico, é a visão do todo através de uma análise de cima para baixo, onde se parte de posicionamentos verdadeiramente estratégicos e amplos para então se chegar a detalhes (implementações). Em termos de custos.. do método, é nitidamente mais barato que o método anterior, além de envolver 
executivos e gerentes com um assunto que definitivamente thes diz respeito.

Por outro lado, não existe um rigor particular na forma como os FCSs individuais possam ser agregados em padrões claros da companhia. Há freqüentes confusões entre os entrevistados na definição do que são os FCSS individuais e os FCSS organizacionais (que não são necessariamente os mesmos).

$\mathrm{Na}$ tabela a seguir, exemplifica-se como são definidas algumas metas em função da identificação de FCSs, para dois casos distintos de indústrias:

Tabela 5: Metas em função dos FCSs (ROCKART (1979))

\begin{tabular}{lll}
\hline Exemplo & Metas & FCS \\
\hline Orientada a lucro (Indústria & Ganhos/participação & Estilo \\
automotiva) & Retorno sobre invest. & Controle de qualidade \\
& Fatia de mercado & Controle de custos \\
& Novos produtos & Padrões energéticos \\
\hline Não orientada a lucro & Excelência em atendimento & Integração regional com \\
(hospital) & médico & outros hospitais \\
& Concordância com & Uso eficaz de recursos \\
& disposições do governo & Monitoramento das \\
& Necessidades futuras para & disposições \\
& saúde & \\
\hline
\end{tabular}

Um terceiro método, baseado no segundo, é mostrado por KAPLAN; NORTON (1992) e conta, atualmente com um respaldo respeitável pela adoção em inúmeras corporações bem sucedidas em matéria de EIS. É o chamado método do "Balanced scorecard".

\subsubsection{Método do "Balanced Scorecard"}

Trata-se de um conjunto de medições (índices) que dão aos gerentes ou executivos segundo KAPLAN; NORTON (1992), uma rápida, porém 
compreensível visão dos negócios. O "Balanced Scorecard" inclui indicadores financeiros de ações já tomadas, e, complementa-as com medidas operacionais sobre:

- Satisfação do consumidor;

- Processos internos e

- Inovações e implementações na organização.

Tais indicadores direcionam a performance financeira futura.

o "Balanced Scorecard" permite aos gerentes visões de negócio a partir de importantes perspectivas, fornecendo respostas à perguntas colocadas na fase de definição de necessidades. Resumidamente, coloca-se as quatro perspectivas:

Perspectiva do consumidor: Como os consumidores nos vêem?

Perspectivas internas: No que devemos nos sobressair?

Perspectiva da inovação e do aprendizado: Podemos continuar a aperfeiçoar e criar valor?

Perspectiva financeira: Como os nossos acionistas nos vêem?

- "Balanced Scorecard" força o gerente a ater-se àquelas informações realmente importantes, focando nas medidas mais criticas tal como no método de análise dos FCSs.

Assim, usa-se dados relativos a tempo, qualidade, performance, serviços, "core competence", produtividade, capacitação dos empregados, tecnologias críticas, custos, etc. 
Na Figura 15, um exemplo genérico mostra como, a partir de metas estabelecidas, define-se medidas (ou indicadores) que sustentarão as respostas às perguntas formuladas.

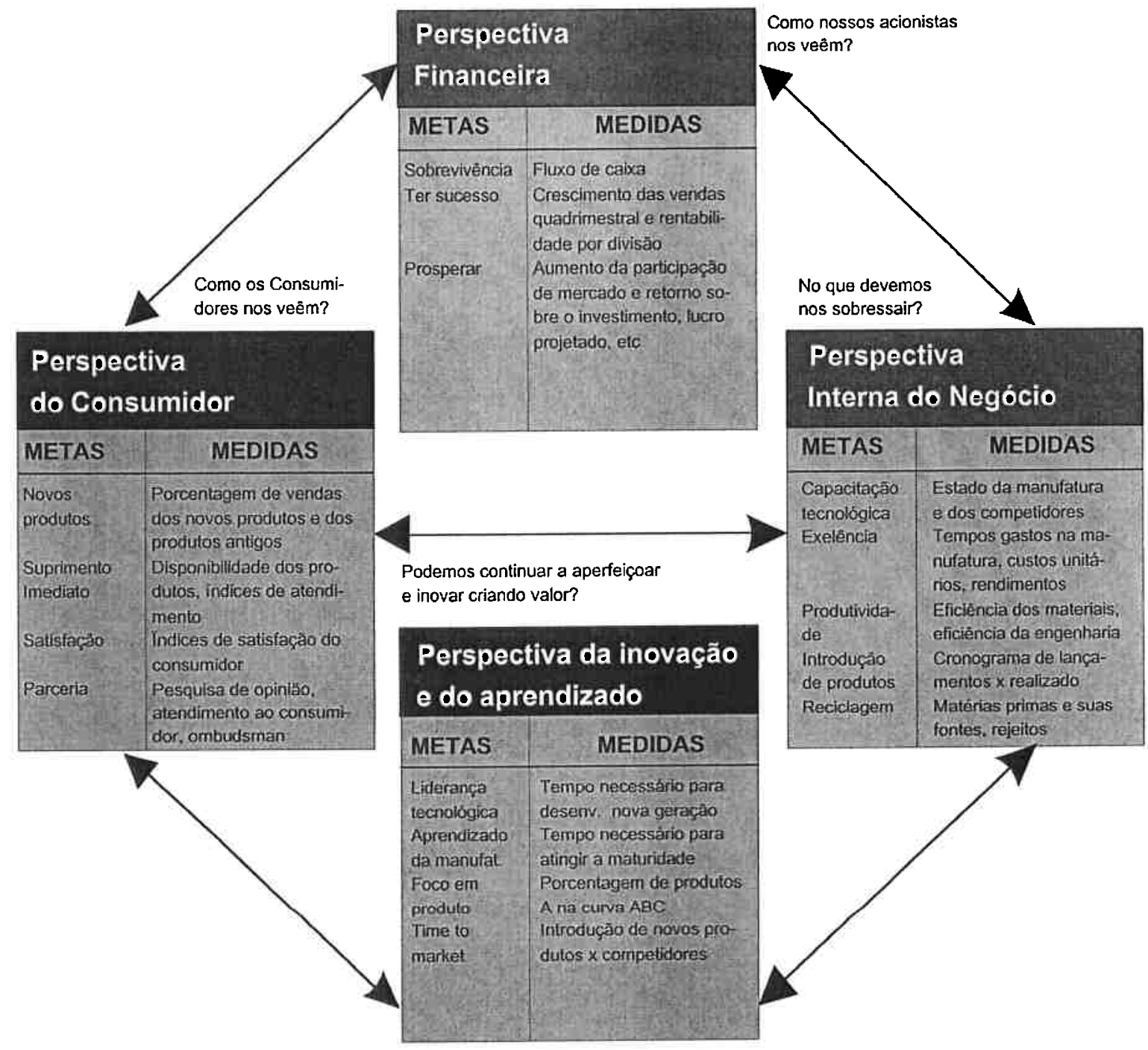

\footnotetext{
Figura 15: Definição de indicadores através de metas (KAPLAN; NORTON (1992)).
}

Há um relacionamento entre as perspectivas, de modo a integrá-las e explicitar suas interdependências. 
Para se "construir" um "Balanced Scorecard", é sugerida uma seqüência de passos que será descrita a seguir:

- Preparação: identificação da unidade de negócio a ser medida ou monitorada;

- Rodada inicial de entrevistas com de 6 a 12 executivos altamente envolvidos com a unidade. Cada um recebe um material descrevendo as visões, missões e estratégias corporativas. São conduzidas entrevistas com cerca de uma hora e meia, para serem identificadas as visões individuais e propostas para a formulação do "Balanced Scorecard";

- Rodada inicial de um "workshop" dos executivos, com discussões em grupo sobre as missões propostas até se chegar a um consenso, para a seguir responder à pergunta: Se minha visão e estratégia funcionar, como minha performance vai se diferenciar para os acionistas, consumidores, processos internos e na habilidade de aperfeiçoamento e inovações?

- Nova rodada de entrevistas para promover a consolidação e a documentação do que foi elaborado até o momento;

- Novo "workshop" envolvendo desta vez uma média gerência e colhendo novas informações, na expectativa de confirmação do consenso;

- É feito um terceiro "workshop" entre todos os envolvidos;

- Implementação, com a definição dos índices, das medidas, das bases de dados, as divulgações do sistema, etc.;

- Revisões periódicas.

Todas as fases mostram grande importância e envolvimento dos executivos. Não havendo consenso inicialmente, o método mostra-se importante inclusive por forçar envolvimento, discussões e o fato de se pensar estrategicamente. 


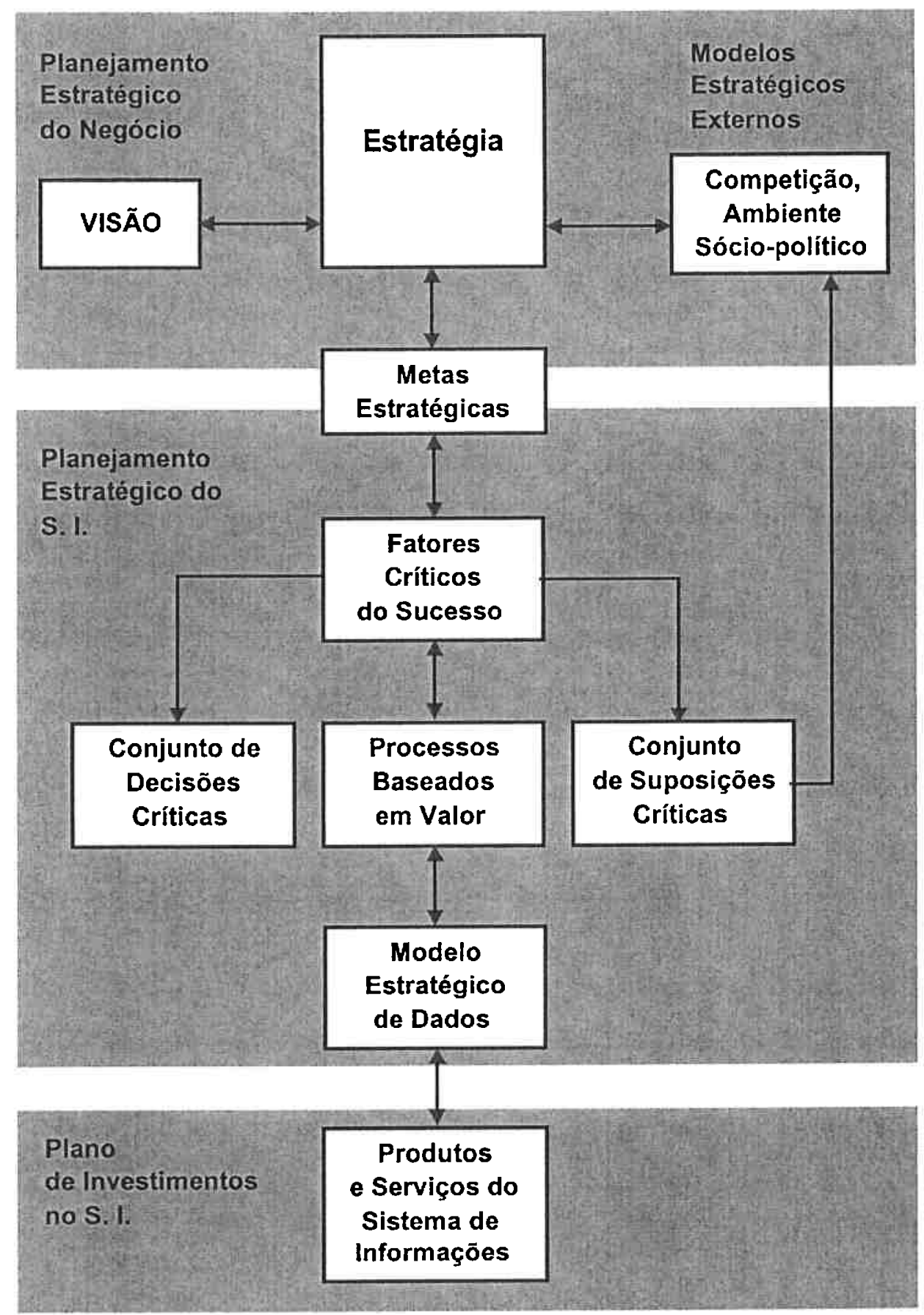

Figura 16: Diagrama de Henderson (KAPLAN; NORTON (1992))

A Figura 16 mostra o diagrama de Henderson, que ilustra sinteticamente $\circ$ fluxo usado na definição e planejamento de sistemas do tipo EIS. Nota-se que todo o planejamento é 
estabelecido a partir da premissa da missão e das estratégias da empresa, para só nos níveis mais detalhados se chegar a dados operacionais. 


\section{Sistema de Informação para Projetos}

\subsection{Particularização do Método "Balanced Scorecard"}

Como já citado anteriormente, a área de projetos (ou de engenharia se quisermos abrir um pouco o contexto) costuma ficar à parte nos processos de definição das bases de dados informacionais, ou seja, no desenho do "data warehouse", na estruturação dos fluxos intracompanhia e extra-companhia.

Os fatores que levam a isto podem ser diversos. Na verdade depende muito do tipo de funcionamento da empresa. Hoje, é muito comum haver inclusive a terceirização da área de engenharia - não que isto a exclua da necessidade de interagir no fluxo de informações.

o que se propõe aqui, é a utilização da metodologia de David P. Norton e Robert $s$. Kaplan (KAPLAN; NORTON (1993)) tomando-se a área de projetos (ou engenharia) como sendo uma empresa em si. Ou seja, é proposta uma particularização da metodologia para uma determinada área da empresa, tendo em vista que a empresa (ver 9.3) é um conjunto de operações, desempenhadas por áreas que se inter-relacionam, e que tais áreas podem ser vistas como empresas distintas. Aliás, é comum na estrutura das empresas que isto ocorra, ou seja, cada área tem autonomia suficiente para definir seu orçamento, para planejar suas atividades, para contratar outras áreas, enquanto não interferir na estratégia global da empresa. É comum exemplos de áreas de destaque que acabam se desmembrando da empresa e formando novas empresas totalmente alinhadas com os objetivos daquelas que as originaram.

- "Balanced scorecard" permite, então, à área de projetos, visões da sua atividade fim (projetar) a partir das mesmas perspectivas anteriormente vistas. 
Analogamente, as perguntas a serem colocadas são:

Perspectiva financeira: Como os nossos acionistas nos vêem? Neste caso, como a empresa nos vê, ou seja, como a área financeira da empresa enxerga os custos demandados pela área de projetos, como a área "cliente" absorve o custo do projeto e, indiretamente, como os acionistas vêem estes custos?

Perspectiva do consumidor: Como os consumidores nos vêem? Neste caso, o consumidor é tanto o consumidor de fato (consumidor final), ou seja, a área de projetos deve estar consciente daquilo que o mercado, expresso pelo comprador do produto deseja realmente obter, mas também é a empresa, representada por algumas áreas que demandam o projeto do produto. Assim, há dois níveis de consumidores: o intermediário ou direto que é a própria empresa, e então o produto é o projeto em si, e o consumidor de fato, vendo o produto como o resultado do projeto.

Perspectivas internas: No que devemos nos sobressair? A área de projetos deveria ter sempre ferramentas para se tornar mais eficiente. Como caracteristica intrínseca da atividade de projetar, deveria ter especiais cuidados no planejamento do projeto, na definição cronológica, na organização das etapas, na qualidade da execução, e no resultado final. Fica claro que isto não ocorre sem um custo (elevado), porém, em indústrias extremamente dependentes da área de projetos, um investimento cada vez maior está sendo feito na nesta área, pois é nela que reside um dos pontos mais estratégicos, que influi na qualidade dos produtos oferecidos ao cliente, e portanto, diretamente nas metas da empresa. 


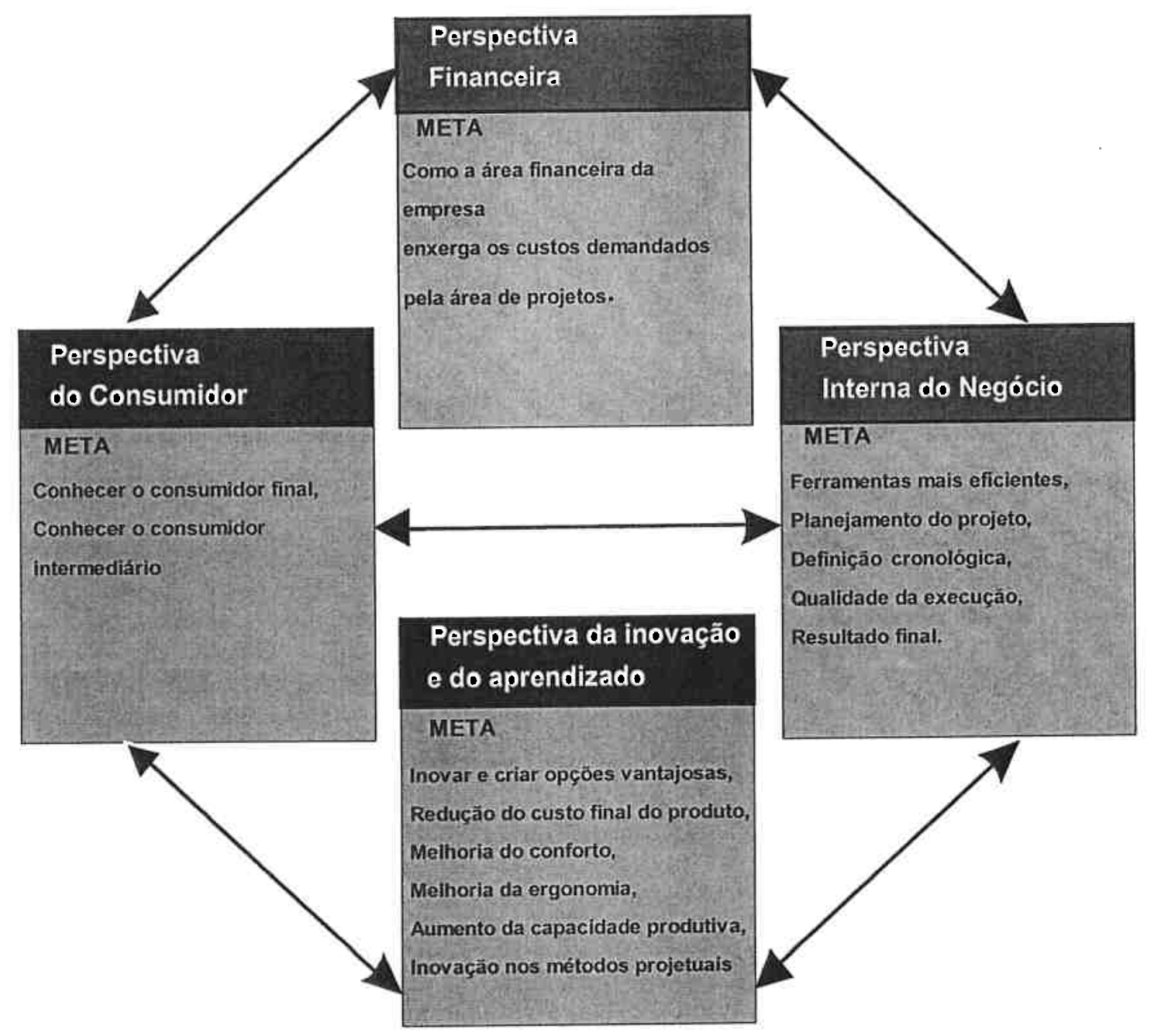

Figura 17: Algumas metas para a área de projetos (modificado de KAPLAN; NORTON (1992).

Perspectiva da inovação e do aprendizado: Podemos continuar a aperfeiçoar e criar valor? Este "cartão" do método "Balanced Scorecard" perde um pouco de seu sentido original na aplicação do método à área de projetos. Não que não deva ser uma meta da área de projeto inovar e criar opções vantajosas, porém, isto é e sempre foi também inerente ao ato de projetar. Não é concebivel (ainda que existam infindáveis exemplos) que se despenda um enorme esforço na atividade projetual para se perpetuar o "status-quo". A demanda do projeto é em função de melhorias, seja reduzindo 
custos, seja aumentando o conforto, a ergonomia, seja ampliando volumes produtivos, etc. Há, por outro lado, neste "cartão" a faceta da inovação nos métodos projetuais e no aprendizado dentro da própria área.

Assim, de uma forma simplificada, é possivel mapear necessidades de informação já com um direcionamento, ou seja, em concordância com os objetivos da empresa.

\subsection{Fatores Específicos da Área de Projetos:}

Segundo KAMINSKI (2000) (ver 9.4), há seis principais aspectos a serem considerados no desenvolvimento de um novo produto: administrativos, técnicos, financeiros, econômicos, jurídicos e legais e de meio ambiente.

Comparativamente, falta o item "perspectivas do consumidor", e os demais itens podem ser reagrupados de forma a atenderem ao método do "Balanced Scorecard". Porém, no texto referido, na verdade, o "ouvir o consumidor" precede os aspectos de desenvolvimento, ou seja, para se levar a cabo um determinado projeto, parte-se da premissa de que a demanda do mercado, ou o anseio do consumidor já foi identificado.

Quanto aos demais itens, como aqui se trata de uma parte da empresa que assume o papel de uma empresa per si, é interessante colocar sob o "cartão" "perspectiva interna do negócio" o subitem: administrativo e sob o "cartão" "perspectivas do consumidor" os sub-itens: jurídicos e legais e de meio ambiente, entendendo que estes representem leituras de anseios do consumidor.

Também é muito particular o desenvolvimento do projeto em etapas, classicamente divididas em: 
- Estudo Preliminar;

- Ante-Projeto e

- Projeto Executivo.

Esta divisão pode assumir outros nomes ou desdobramentos, mas no dia a dia da área de projetos, o que se verifica são estas três grandes fases que possuem caracteristicas bastante definidas. Assim, no estudo preliminar, é predominante a atividade de "ouvir - consumidor" de identificar seus anseios, já no ante-projeto, há um balanceamento entre $\circ$ atendimento de requisitos de custos, legais, ambientais, simulações de retorno sobre o investimento e outros. o projeto executivo detalha tudo o que foi levantado anteriormente, sempre levando em conta as perspectivas abordadas no método "Balanced Scorecard", porém, a "perspectiva financeira" é a predominante.

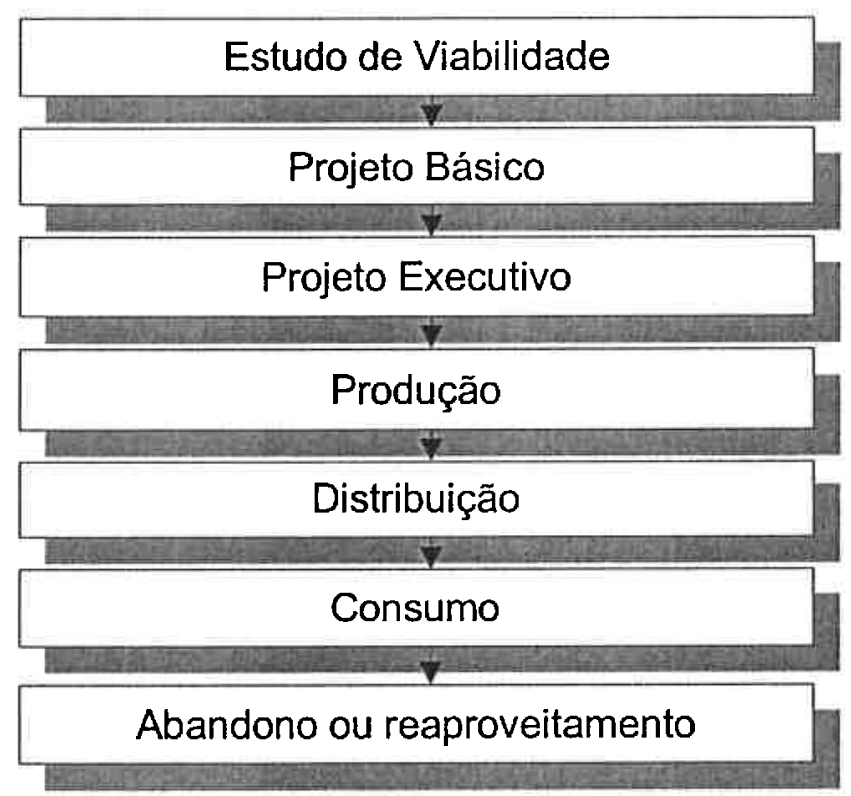

Figura 18: Fases de desenvolvimento de um projeto (ASIMOV (1962)). ASIMOV (1962), entre outros, especifica sete fases que podem ser vistas na Figura 18, onde o estudo de viabilidade pode ser 
equiparado ao projeto preliminar e o projeto básico ao anteprojeto.

Levando em conta o escopo abrangido pelo presente trabalho, "Produção", "Distribuição", "Consumo" e "Abandono ou reaproveitamento" são fases do desenvolvimento do produto, ou componentes de seu ciclo de vida, e não fases do projeto, ou da atividade de projetar propriamente dita, uma vez que cada um destes itens passa por um estudo de viabilidade, um projeto básico e um projeto executivo. Isto não exclui de forma alguma a necessidade da área de projeto estar completamente envolvida com tais itens. Todas estas fases são definidoras inclusive do "design" do produto, ou seja, a área de projeto, bem como a empresa como um todo, vão definir o produto em função de como ele será utilizado, de como será sua logistica, a cadeia de distribuição, qual o impacto na área de produção (traduzido em necessidades de configurações de máquinas ou mudanças em linhas de montagem entre outras), como será $\circ$ abandono do produto (refletindo na escolha dos materiais: recicláveis, biodegradáveis, reutilizáveis, etc.) ou na previsão de formas de se recolher o produto, armazená-lo quando não mais utilizável ${ }^{19}$, etc.

19 Recentemente, as empresas produtoras de herbicidas se viram obrigadas a rever o projeto de suas embalagens. Consideradas perigosas por conterem residuos quimicos, as embalagens foram alvo de lei federal que obriga as empresas enquadradas neste caso a recolherem as embalagens utilizadas $e$ as depositar em locais adequados. Estas embalagens não podem ser re-utilizadas, recicladas ou dispostas em locais de uso humano. Cabe ao departamento de projetos colaborar na resolução deste problema. 
Em OGLIARI (1999) é feito um estudo comparativo entre metodologias de projeto de vários autores. A Figura 19 mostra a sintese da comparação entre as metodologias de quatro autores.

Ao final da comparação, Ogliari chega ao que ele chama de "Modelo de Consenso", no qual prevalecem as quatro etapas a seguir: "Projeto Informacional", "Projeto Conceitual", Projeto Preliminar" e "Projeto Detalhado".

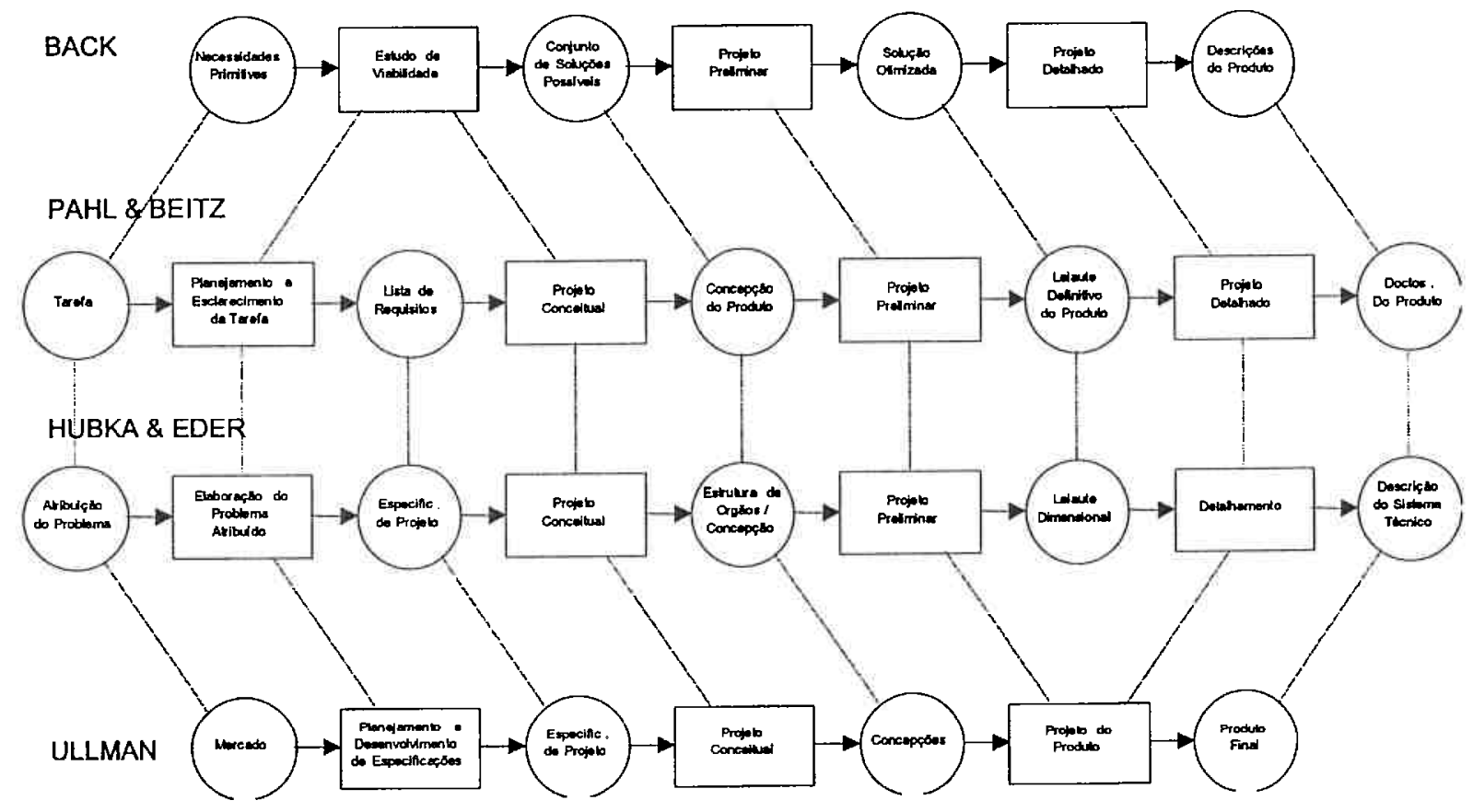

Figura 19: Sintese comparativa entre metodologias de Projeto (OGLIARI, 1999) ${ }^{20}$

20 As metodologias citadas constam da seguinte bibliografia: BACK, N. Metodologia de Projeto de Produtos Industriais, Ed. Guanabara 
Interessante de se notar no "modelo de consenso" a inclusão do "Projeto Informacional" como uma das etapas do projeto. Ogliari defini "Projeto Informacional" como o conjunto de informações de mercado tais como "os interesses ou as manifestações dos clientes de projeto, ou seja, daquelas pessoas ou organizações que se relacionam, direta ou indiretamente, com o projeto ou produto em questão. Tais informações, geralmente genéricas e qualitativas, são transformadas em especificações de projeto, ou seja, em requisitos qualificados, que estabelecem os principais problemas técnicos a serem resolvidos e as restrições de solução."

Portanto, na análise de Ogliari, a informação de mercado configura-se como uma entrada inicial no processo. É bem verdade que neste momento inicial, o volume de informação de mercado é muito maior quando comparado com o decorrer do processo, entretanto, em vários momentos, torna-se necessária a consulta de informações mercadológicas, num processo dinâmico de adequação do projeto às necessidades mutantes do mercado. Além disso, o termo "informação" traduz-se num significado bem mais amplo do que simplesmente dados de mercado, e, desta forma, em todas as etapas do projeto ocorre uma constante leitura, análise e utilização das informações concernentes ao projeto.

Dois, Rio de Janeiro, 1983; PAHL, G.; BEITZ, W., Engineering Design: A Systematic Approach, Springer-Verlag London Limited, London, 1996; HUBKA, V. EDER, E. W. Design Science: Introduction to Needs, Scope and Organization of Engineering Design Knowledge, Springer-Verlag London Limited, London, 1996 e ULLMAN, D. G., A New View on Function Modeling, in: International Conference on Engineering Design - IDEC93, Netherlands, 1993. 
Comparando autores, portanto, pode-se assumir como no mínimo suficiente a classificação composta de três etapas como proposto anteriormente.

Na Tabela 6, adaptada de KAMINSKI (2000), há uma exemplificação do planejamento operacional do desenvolvimento de um determinado produto. Tal classificação é extremamente útil no processo identificador de fontes de dados. 
Tabela 6: Exemplo de setores envolvidos e responsáveis pelas atividades de desenvolvimento de um produto.

\begin{tabular}{|l|l|l|l|l|}
\hline \multirow{2}{*}{} & & & \\
\hline
\end{tabular}

Os quadrados em cinza indicam envolvimento da área e os com um quadrado preto indicam o setor responsável pela atividade.

Além disso, a tabela se divide em fases do desenvolvimento, indicando os pontos de interação mais intensa em cada uma das fases. Note-se que o setor de engenharia aparece frequentemente como responsável por atividades. Isto mostra a importância da área 
no desenvolvimento do produto. Numa primeira aproximação seria conveniente e extremamente simplificador considerar como atividädes demandadoras de informação para a área de projetos apenas aquelas nas quais as áreas técnica e de engenharia aparecem como responsáveis. Entretanto, esta simplificação é na verdade simplista, e elimina subsidios cruciais no decorrer do desenvolvimento do produto. Assim, qualquer proposta de identificação de fontes de informação e organização das mesmas deve preferencialmente levar em conta todas as etapas abordadas na Tabela 6 .

Das atividades listadas na Tabela 6, apenas não serão consideradas, nesta proposta, 3 que constam da fase de lançamento, que são: "Estratégia de Marketing para o Lançamento", pois esta atividade será feita pela área de marketing principalmente e utilizará dados gerados pela área de Engenharia no decorrer do desenvolvimento do produto; "Definição de Preço de Venda", que também será feita considerando dados de saida da área citada e "Teste de Mercado", que poderá ter o envolvimento da área de Engenharia, mas não dentro desta atividade, mas como uma retroalimentação em etapas anteriores.

Assim, considerando as áreas descritas na Tabela 6, que podem variar de empresa para empresa, foi feito um levantamento dentro da empresa na qual trabalho ${ }^{21}$, bem como observando $\circ$ que comumente acontece em empresas de grande porte (onde normalmente todas ou a maioria das áreas dispõem de sistemas automatizados)

Este levantamento não é definitivo, no sentido de que nada impede que os sistemas aqui listados sejam utilizados em áreas não

21 Monsanto do Brasil - parte de pesquisa visando o planejamento estratégico da área de sistemas da empresa feita em julho de 2000. 
listadas na Tabela 7. Apenas trata-se de uma recomendação (bastante ampliada, diga-se de passagem) para eventuais disponibilizações de licenças de sistemas ou como base para a configuração dos perfis de utilização para os módulos de um sistema.

Tabela 7: Sistemas envolvidos nas atividades de cada área da empresa (levantamento de sistemas dentro da empresa na qual o autor atua).

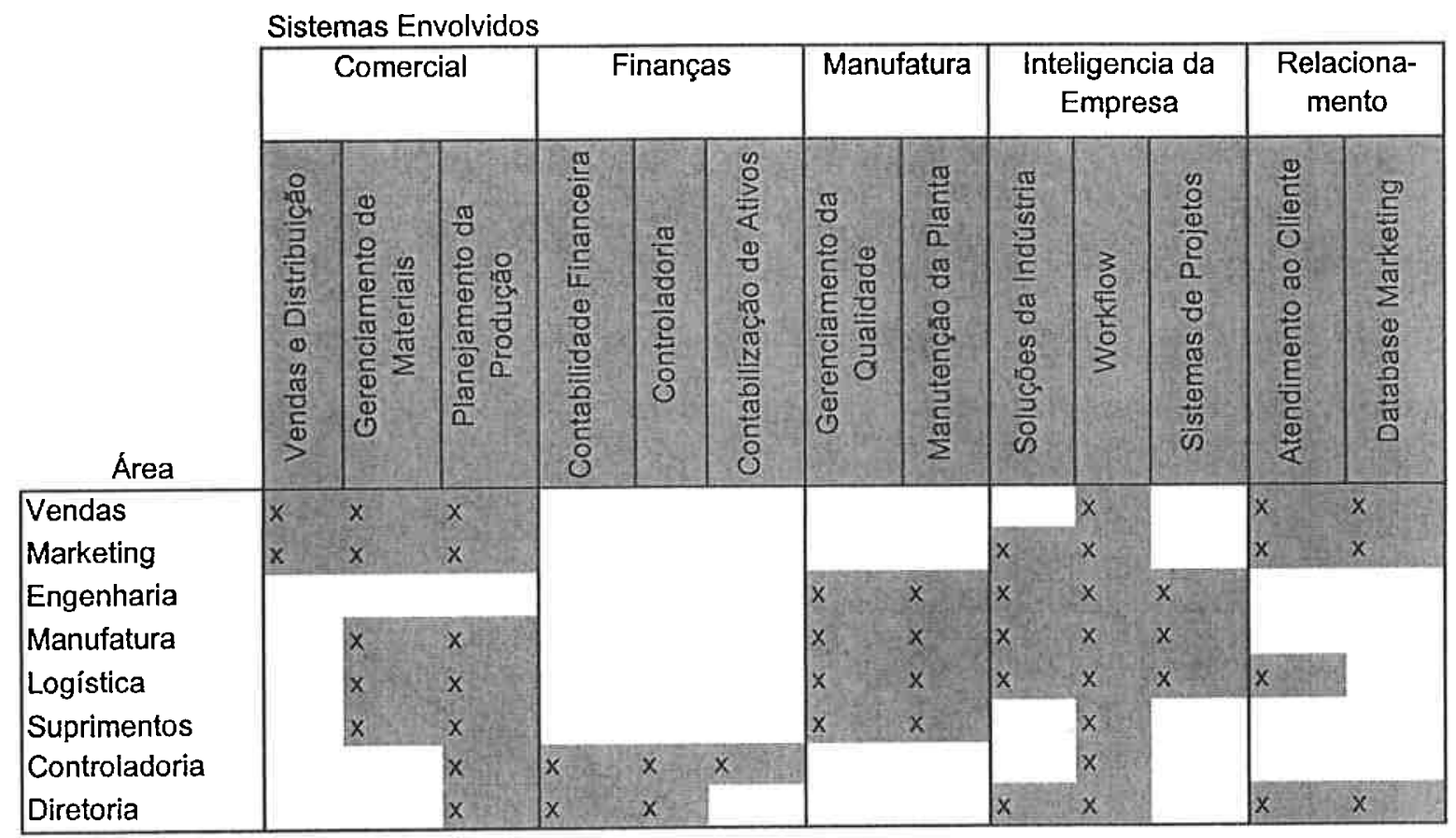

Na Tabela 7, os sistemas estão divididos em módulos, seguindo aproximadamente a modularização feita pelos principais fornecedores de sistemas ERP (ver Figura 4).

É importante deixar claro que o método do "Balanced Scorecard" não impõe qualquer forma de controle, mas apenas define uma visão ou uma estratégia. Como já foi apresentado, o método estabelece as metas, mas assume que as pessoas poderão adotar qualquer 
comportamento ou ação para atingi-las. As medidas detectadas pelo método são formas de direcionar as pessoas.

Aqui, então, igualmente, não se pretende indicar formas de se atingir as metas identificadas, mas apenas trazer ao conhecimento das pessoas envolvidas com a atividade de projetar e especificamente à área de projetos, indicadores que suportem as ações a serem tomadas. Trata-se de uma forma de tentar melhorar o nível de informação disponível dentro da área de projetos. Se esta informação vai ser bem utilizada, isto está fora do escopo, entretanto, quero crer que uma empresa que atinge um certo grau de maturidade e se preocupa com a qualidade de sua própria informação estará plenamente habilitada para traçar planos e atingir suas metas.

\subsection{Definição dos conteúdos de cada cartão do método "Balanced scorecard".}

Fazendo um cruzamento entre a Tabela 7 e a Figura 17, é possível identificar quais sistemas em quais áreas são de fato relevantes na metodologia do "Balanced Scorecards" e em que "cartões" seria possivel enquadrar cada um deles.

Nas tabelas a seguir, é feito um mapeamento, omitindo os sistemas que não tem relacionamento com o processo de desenvolvimento do produto.

A Tabela 8 mostra o cartão da perspectiva financeira. Assim, a maioria dos sistemas contribui no fornecimento de dados de custos, pois são estes dados que permitirão tanto a previsão dos custos futuros, quanto a auditoria dos mesmos. Uma vez definidos os 
cartões, é possível acompanhar o desempenho dos itens, através de ferramentas ligadas a bancos de dados de informações ${ }^{22}$.

Tabela 8: Análise do cartão da Perspectiva Financeira no método do "Balanced Scorecard" para o desenvolvimento de projeto de produto em uma empresa comercial.

\begin{tabular}{|l|l|l|}
\hline Perspectiva Financeira \\
\hline Área & Módulo de Sistema & Como a Empresa vê os custos do Projeto? \\
\hline Vendas & Vendas e Distribuição & Custos referentes à venda do novo produto \\
\cline { 2 - 3 } & $\begin{array}{l}\text { Gerenciamento de } \\
\text { Materiais }\end{array}$ & $\begin{array}{l}\text { Custos referentes ao material necessário à venda do } \\
\text { novo produto }\end{array}$ \\
\hline \multirow{5}{*}{ Marketing } & $\begin{array}{l}\text { Gerenciamento de } \\
\text { Materiais }\end{array}$ & Custo de material promocional \\
\cline { 2 - 3 } & Soluções da Indústria & $\begin{array}{l}\text { Custo da aquisição do conhecimento sobre } \\
\text { concorrentes }\end{array}$ \\
\cline { 2 - 3 } & Workflow & $\begin{array}{l}\text { Custo da definição do workflow para atendimento ao } \\
\text { novo produto }\end{array}$ \\
\cline { 2 - 4 } & $\begin{array}{l}\text { Atendimento ao } \\
\text { Cliente }\end{array}$ & Custo do atendimento ao cliente \\
\cline { 2 - 3 } & Database Marketing & Custo do gerenciamento dos dados de clientes \\
\hline Engenharia & $\begin{array}{l}\text { Gerenciamento da } \\
\text { Qualidade }\end{array}$ & Custo da qualidade do projeto \\
\cline { 2 - 3 } & Manutenção da Planta & $\begin{array}{l}\text { Custo do projeto de adequação da planta ao novo } \\
\text { produto }\end{array}$ \\
\hline
\end{tabular}

22 A Pilot software, por exemplo, comercializa um aplicativo denominado "Pilot Balanced Scorecard" que, a partir de uma base de dados do tipo "infocubo", cujos parâmetros de visões são criteriosamente estabelecidos de acordo com o método do "Balanced scorecard", é capaz de exibir medidores bastante fáceis de serem lidos (batizados de "speedometers" ou velocímetros) e que podem ser detalhados, mostrando dados de análises de tendências, comparativos com o mercado, análises de desvios e diversos relatórios. Evidentemente, tais informações tem que ser modeladas cautelosamente, uma vez que $\circ$ aplicativo não passa de uma interface configurável entre a fonte de informações e o receptor. 


\begin{tabular}{|c|c|c|}
\hline \multicolumn{3}{|c|}{ Perspectiva Financeira } \\
\hline Área & Módulo de Sistema & Como a Empresa vê os custos do Projeto? \\
\hline \multirow[t]{3}{*}{. } & Soluções da Indústria & $\begin{array}{l}\text { Custo da aquisição do conhecimento sobre } \\
\text { concorrentes e do estado da arte, inclusive de } \\
\text { pesquisas tecnológicas }\end{array}$ \\
\hline & Workflow & Custo do fluxo de informação de projeto \\
\hline & Sistemas de Projetos & Custo da definição e do desenvolvimento do projeto \\
\hline \multirow[t]{5}{*}{ Manufatura } & $\begin{array}{l}\text { Gerenciamento de } \\
\text { Materiais }\end{array}$ & Custo da matéria prima e de seu gerenciamento \\
\hline & $\begin{array}{l}\text { Planejamento da } \\
\text { Produção }\end{array}$ & Custo do planejamento da produção \\
\hline & $\begin{array}{l}\text { Gerenciamento da } \\
\text { Qualidade }\end{array}$ & $\begin{array}{l}\text { Custo da qualidade do produto em seu processo } \\
\text { produtivo }\end{array}$ \\
\hline & Manutenção da Planta & $\begin{array}{l}\text { Custo das alterações requeridas na planta e das } \\
\text { manutenções previstas }\end{array}$ \\
\hline & Soluções da Indústria & $\begin{array}{l}\text { custo da aquisição do conhecimento da indústria, bem } \\
\text { como da análise e aquisição de novas tecnologias }\end{array}$ \\
\hline \multirow[t]{5}{*}{ Logística } & $\begin{array}{l}\text { Gerenciamento de } \\
\text { Materiais }\end{array}$ & $\begin{array}{l}\text { Custo do transporte, armazenagem e manuseio dos } \\
\text { produtos, matérias primas, produtos semi-acabados, } \\
\text { etc., durante a produção, armazenagem e distribuição }\end{array}$ \\
\hline & \begin{tabular}{|l|} 
Planejamento da \\
Produçăo
\end{tabular} & Custo do planejamento da produção \\
\hline & Soluções da Indústria & $\begin{array}{l}\text { Custo da aquisição do conhecimento da indústria, bem } \\
\text { como da análise e aquisição de novas tecnologias }\end{array}$ \\
\hline & Workflow & Custo do fluxo de informação de logística \\
\hline & $\begin{array}{l}\text { Atendimento ao } \\
\text { Cliente }\end{array}$ & Custo do atendimento ao cliente \\
\hline \multirow[t]{4}{*}{ Suprimentos } & $\begin{array}{l}\text { Gerenciamento de } \\
\text { Materiais }\end{array}$ & Custo da matéria prima e de seu gerenciamento \\
\hline & $\begin{array}{l}\text { Planejamento da } \\
\text { Produção }\end{array}$ & $\begin{array}{l}\text { Custo da manutenção do estoque de forma adequada à } \\
\text { demanda de produção }\end{array}$ \\
\hline & $\begin{array}{l}\text { Gerenciamento da } \\
\text { Qualidade }\end{array}$ & Custo da verificação da qualidade da matéria prima \\
\hline & Manutenção da Planta & $\begin{array}{l}\text { Custo da manutenção do estoque de reposição e } \\
\text { reparos na planta }\end{array}$ \\
\hline \multirow[t]{2}{*}{ Controladoria } & $\begin{array}{l}\text { Contabilidade } \\
\text { Financeira }\end{array}$ & $\begin{array}{l}\text { Custo da adequação do produto aos requisitos } \\
\text { contábeis da empresa }\end{array}$ \\
\hline & Controladoria & $\begin{array}{l}\text { Definição de formas de análise de desempenho para o } \\
\text { novo produto }\end{array}$ \\
\hline \multirow[t]{2}{*}{ Diretoria } & Workflow & Análises e aprovações das diversas fases \\
\hline & $\begin{array}{l}\text { Atendimento ao } \\
\text { Cliente }\end{array}$ & Diretrizes de comunicação e de introdução do produto \\
\hline
\end{tabular}

Na Tabela 9 é vista a perspectiva do consumidor, ou seja, alguns aspectos que podem ser levantados a partir dos diversos sistemas ou módulos de sistemas disponiveis na empresa. 
Note que a tabela mostra aspectos subjetivos, tais como "visões", "posicionamentos", "definições" e outros, que são na verdade interpretações dos dados disponíveis nos bancos de dados da empresa.

Tabela 9: Análise do cartão da Perspectiva do Consumidor no método do "Balanced Scorecard" para o desenvolvimento de projeto de produto em uma empresa comercial.

\begin{tabular}{|c|c|c|}
\hline \multicolumn{3}{|c|}{ Perspectiva do Consumidor } \\
\hline Área & Módulo de Sistema & $\begin{array}{l}\text { Conhecer o consumidor final, Conhecer o } \\
\text { consumidor intermediário }\end{array}$ \\
\hline \multirow[t]{4}{*}{ Vendas } & Vendas e Distribuição & $\begin{array}{l}\text { Visão da abrangência do escopo do projeto em termos } \\
\text { geográficos, Medida da demanda projetada para o } \\
\text { mercado. }\end{array}$ \\
\hline & $\begin{array}{l}\text { Gerenciamento de } \\
\text { Materiais }\end{array}$ & $\begin{array}{l}\text { Dimensiona esforços da área de vendas para a inclusão } \\
\text { do novo produto, Mostra o impacto (por projeção) da } \\
\text { introdução de novos produtos }\end{array}$ \\
\hline & Atendimento ao Cliente & $\begin{array}{l}\text { Visão do Consumidor de como deve ser o processo do } \\
\text { projeto, Visão do consumidor de como deve ser o novo } \\
\text { produto }\end{array}$ \\
\hline & Database Marketing & $\begin{array}{l}\text { Informações especificas sobre a visão do cliente quanto } \\
\text { ao projeto e ao produto podem ser armazenadas }\end{array}$ \\
\hline \multirow[t]{3}{*}{ Marketing } & Soluções da Indústria & $\begin{array}{l}\text { Permite a confrontação com os competidores da } \\
\text { indústria }\end{array}$ \\
\hline & Atendimento ao Cliente & $\begin{array}{l}\text { Visão do consumidor de como deve ser o processo do } \\
\text { projeto e o novo produto }\end{array}$ \\
\hline & Database Marketing & $\begin{array}{l}\text { Informações específicas sobre a visão do cliente quanto } \\
\text { ao projeto e quando ao produto podem ser } \\
\text { armazenadas }\end{array}$ \\
\hline \multirow[t]{4}{*}{ Engenharia } & $\begin{array}{l}\text { Gerenciamento da } \\
\text { Qualidade }\end{array}$ & $\begin{array}{l}\text { Posicionamento do nivel de qualidade com relação ao } \\
\text { desejado pelo mercado, Adequação da qualidade aos } \\
\text { anseios do consumidor, Definição das possibilidades } \\
\text { quanto ao uso de tecnologias de ponta }\end{array}$ \\
\hline & Manutençāo da Planta & $\begin{array}{l}\text { Visão do consumidor de como deve ser o processo de } \\
\text { produção do produto }\end{array}$ \\
\hline & Soluções da Indústria & Definição do grau de tecnologia a ser adotado \\
\hline & Sistemas de Projetos & $\begin{array}{l}\text { Visão do Consumidor de Como deve ser o processo do } \\
\text { projeto }\end{array}$ \\
\hline \multirow[t]{2}{*}{ Manufatura } & $\begin{array}{l}\text { Gerenciamento de } \\
\text { Materiais } \\
\end{array}$ & $\begin{array}{l}\text { Mostra o impacto (por projeção) da introdução de novos } \\
\text { produtos }\end{array}$ \\
\hline & $\begin{array}{l}\text { Planejamento da } \\
\text { Produção }\end{array}$ & $\begin{array}{l}\text { Definição de prazos, cronogramas e adequações de } \\
\text { planta em função do mercado }\end{array}$ \\
\hline
\end{tabular}




\begin{tabular}{|c|c|c|}
\hline \multicolumn{3}{|c|}{ Perspectiva do Consumidor } \\
\hline Área & Módulo de Sistema & $\begin{array}{l}\text { Conhecer o consumidor final, Conhecer o } \\
\text { consumidor intermediário }\end{array}$ \\
\hline & $\begin{array}{l}\text { Gerenciamento da } \\
\text { Qualidade }\end{array}$ & $\begin{array}{l}\text { Visão do consumidor de como deve ser o processo de } \\
\text { produção do produto }\end{array}$ \\
\hline & Manutenção da Planta & $\begin{array}{l}\text { Visão do consumidor de como deve ser o processo de } \\
\text { produção do produto }\end{array}$ \\
\hline & Soluções da Indústria & Definição do grau de tecnologia a ser adotado \\
\hline Logística & $\begin{array}{l}\text { Gerenciamento da } \\
\text { Qualidade }\end{array}$ & $\begin{array}{l}\text { Definição de como o cliente espera ter acesso ao } \\
\text { produto }\end{array}$ \\
\hline \multirow[t]{2}{*}{ Suprimentos } & $\begin{array}{l}\text { Gerenciamento de } \\
\text { Materiais }\end{array}$ & $\begin{array}{l}\text { Visão da preocupação do mercado quanto à matéria- } \\
\text { prima utilizada, como por exemplo, se são usados } \\
\text { materiais recicláveis, se não agride ecologicamente o } \\
\text { meio, etc.; Verificação da possível utilização de } \\
\text { recursos já existentes ou resultantes de outros } \\
\text { processos implantados na empresa }\end{array}$ \\
\hline & $\begin{array}{l}\text { Gerenciamento da } \\
\text { Qualidade }\end{array}$ & $\begin{array}{l}\text { Visão das preocupações do mercado quanto à } \\
\text { procedência da matéria-prima }\end{array}$ \\
\hline
\end{tabular}

Os dois últimos cartões (Tabela 10 e Tabela 11), Perspectiva Interna do Negócio e Perspectiva da Inovação e do Aprendizado, tem uma aspecto bem mais subjetivo, e a utilização de dados de sistemas torna-se mais dificil, ou menos imediata. Ainda assim, vale a pena um esforço para agregar algumas informações transacionais a outras fontes de dados existentes na empresa, tais como planos de metas, diretrizes de atuação, relatórios fornecidos por terceiros, pesquisas de mercado e outras.

Tabela 10: Análise do cartão da Perspectiva Interna do Negócio no método do "Balanced Scorecard" para o desenvolvimento de projeto de produto em uma empresa comercial.

\begin{tabular}{|l|l|l|}
\hline Perspectiva Interna do Negócio \\
\hline Área & Módulo de Sistema & $\begin{array}{l}\text { Ferramentas mais Eficientes, Planejamento do } \\
\text { projeto, Definição Cronológica, Qualidade da } \\
\text { Execução, Resultado Final }\end{array}$ \\
\hline Vendas & Vendas e Distribuição & $\begin{array}{l}\text { Como o desenho do produto pode agregar valor nas } \\
\text { atividades de vendas e distribuição. }\end{array}$ \\
\cline { 2 - 3 } & $\begin{array}{l}\text { Gerenciamento de } \\
\text { Materiais }\end{array}$ & $\begin{array}{l}\text { Qual o comprometimento no mercado do } \\
\text { posicionamento da atual linha de produtos }\end{array}$ \\
\hline
\end{tabular}




\begin{tabular}{|c|c|c|}
\hline \multicolumn{3}{|c|}{ Perspectiva Interna do Negócio } \\
\hline \multirow[t]{2}{*}{ Área } & Módulo de Sistema & $\begin{array}{l}\text { Ferramentas mais Eficientes, Planejamento do } \\
\text { projeto, Definição Cronológica, Qualidade da } \\
\text { Execução, Resultado Final }\end{array}$ \\
\hline & $\begin{array}{l}\text { Planejamento da } \\
\text { Produção }\end{array}$ & $\begin{array}{l}\text { Como gerar melhores resultados através de um } \\
\text { planejamento mais direcionado à melhoria dos métodos }\end{array}$ \\
\hline \multirow[t]{4}{*}{ Marketing } & Vendas e Distribuição & $\begin{array}{l}\text { Indicativos de mercado referentes à demanda por } \\
\text { qualidade, rapidez, etc. }\end{array}$ \\
\hline & Soluções da Indústria & $\begin{array}{l}\text { Avaliação da concorrência e das vantagens que } \\
\text { poderiam ser obtidas utilizando-se tecnologias de ponta }\end{array}$ \\
\hline & Atendimento ao Cliente & $\begin{array}{l}\text { Como o atendimento pode ser direcionado para coletar } \\
\text { informações mais úteis no desenvolvimento do projeto }\end{array}$ \\
\hline & Database Marketing & $\begin{array}{l}\text { Qual a necessidade temporal e geográfica do produto } \\
\text { por parte do cliente }\end{array}$ \\
\hline \multirow[t]{5}{*}{ Engenharia } & $\begin{array}{l}\text { Gerenciamento da } \\
\text { Qualidade }\end{array}$ & $\begin{array}{l}\text { De que forma o controle de qualidade pode ser mais } \\
\text { eficiente e racional }\end{array}$ \\
\hline & Manutenção da Planta & $\begin{array}{l}\text { Como organizar as iniciativas de manutenção de forma } \\
\text { a otimizar a produção do novo produto }\end{array}$ \\
\hline & Soluções da Indústria & $\begin{array}{l}\text { Conhecer o estado da arte no campo da pesquisa e as } \\
\text { melhores soluções da indústria }\end{array}$ \\
\hline & Workflow & $\begin{array}{l}\text { Como o fluxo interno de informações entre niveis } \\
\text { hierárquicos pode facilitar o processo de projetar }\end{array}$ \\
\hline & Sistemas de Projetos & $\begin{array}{l}\text { Extrair o máximo de recursos possiveis oferecidos } \\
\text { pelos sistemas de projetos }\end{array}$ \\
\hline Manufatura & $\begin{array}{l}\text { Gerenciamento de } \\
\text { Materiais }\end{array}$ & $\begin{array}{l}\text { Otimizar utilização de recursos, Gerar } \\
\text { reaproveitamentos internos }\end{array}$ \\
\hline \multirow[t]{3}{*}{ Logística } & $\begin{array}{l}\text { Gerenciamento de } \\
\text { Materiais }\end{array}$ & Otimizar utilização de recursos \\
\hline & \begin{tabular}{|l|} 
Planejamento da \\
Produção
\end{tabular} & $\begin{array}{l}\text { Utilização de baixos estoques, Métodos inovadores e } \\
\text { eficientes }\end{array}$ \\
\hline & $\begin{array}{l}\text { Gerenciamento da } \\
\text { Qualidade }\end{array}$ & $\begin{array}{l}\text { Verificar formas de melhorar a qualidade nos processos } \\
\text { referentes a logística, visando a obtenção de um } \\
\text { produto final de melhor qualidade }\end{array}$ \\
\hline \multirow[t]{2}{*}{ Suprimentos } & $\begin{array}{l}\text { Gerenciamento de } \\
\text { Materiais }\end{array}$ & Otimizar utilização de recursos \\
\hline & $\begin{array}{l}\text { Planejamento da } \\
\text { Produção }\end{array}$ & $\begin{array}{l}\text { Utilização de baixos estoques, Métodos inovadores e } \\
\text { eficientes }\end{array}$ \\
\hline
\end{tabular}

Finalmente, no cartão referente à Perspectiva da Inovação e do Aprendizado, os dados existentes nos sistemas transacionais servem mais como uma base sobre a qual é possivel se fazer projeções ou extrapolações, mas dificilmente o dado pode ser usado como ele é originalmente, a menos que se trate de um sistema de "inteligência", ou um banco de dados de conhecimento, como é o caso do item "soluções da indústria". 
Tabela 11: Análise do cartão "Perspectiva da Inovação e do Aprendizado" do método "Balanced Scorecard" para desenvolvimento de projeto de produto.

\begin{tabular}{|c|c|c|}
\hline \multicolumn{3}{|c|}{ Perspectiva da Inovação e do Aprendizado } \\
\hline Área & Módulo de Sistema & $\begin{array}{l}\text { Inovar e Criar Opções Vantajosas, Redução do } \\
\text { Custo Final do Produto, Melhoria do Conforto, } \\
\text { Melhoria da Ergonomia, Aumento da Capacidade } \\
\text { Produtiva, Inovação nos métodos projetuais }\end{array}$ \\
\hline Vendas & Vendas e Distribuição & $\begin{array}{l}\text { Análise dos métodos de vendas e visão da aderência } \\
\text { aos requisitos do novo produto }\end{array}$ \\
\hline \multirow[t]{3}{*}{ Marketing } & Soluções da Indústria & $\begin{array}{l}\text { Comparação com a concorrência, visão dos anseios } \\
\text { dos consumidores }\end{array}$ \\
\hline & Atendimento ao Cliente & $\begin{array}{l}\text { Busca de interação com o consumidor e utilização de } \\
\text { suas expectativas como contribuição na melhoria do } \\
\text { produto/ serviço }\end{array}$ \\
\hline & Database Marketing & $\begin{array}{l}\text { Capacidade de análise e interpretação do perfil do } \\
\text { consumidor, bem como das vontades destes }\end{array}$ \\
\hline \multirow[t]{4}{*}{ Engenharia } & $\begin{array}{l}\text { Gerenciamento da } \\
\text { Qualidade }\end{array}$ & $\begin{array}{l}\text { Medição dos níveis de qualidade e análise dos pontos } \\
\text { criticos }\end{array}$ \\
\hline & Manutenção da Planta & $\begin{array}{l}\text { Avaliação do desempenho da planta, dos pontos } \\
\text { críticos da manutenção e dos custos envolvidos }\end{array}$ \\
\hline & Soluções da Indústria & $\begin{array}{l}\text { Análise das possibilidades disponibilizadas pelos } \\
\text { avanços tecnológicos }\end{array}$ \\
\hline & Sistemas de Projetos & $\begin{array}{l}\text { Aumento da qualidade do projeto, resultando em } \\
\text { melhoria do produto }\end{array}$ \\
\hline \multirow[t]{5}{*}{ Manufatura } & $\begin{array}{l}\text { Gerenciamento de } \\
\text { Materiais }\end{array}$ & $\begin{array}{l}\text { Otimizar utilização de recursos, Gerar } \\
\text { reaproveitamentos internos }\end{array}$ \\
\hline & $\begin{array}{l}\text { Planejamento da } \\
\text { Produção }\end{array}$ & $\begin{array}{l}\text { Avaliação de formas de melhorar a resposta da } \\
\text { produção às necessidades da empresa e do mercado, } \\
\text { possibilitando programações em função da demanda } \\
\text { medida instantaneamente }\end{array}$ \\
\hline & $\begin{array}{l}\text { Gerenciamento da } \\
\text { Qualidade }\end{array}$ & $\begin{array}{l}\text { Medição dos niveis de qualidade e análise dos pontos } \\
\text { críticos }\end{array}$ \\
\hline & Manutenção da Planta & $\begin{array}{l}\text { Avaliação do desempenho da planta, dos pontos } \\
\text { críticos da manutenção e dos custos envolvidos }\end{array}$ \\
\hline & Soluções da Indústria & $\begin{array}{l}\text { Análise das possibilidades disponibilizadas pelos } \\
\text { avanços do setor }\end{array}$ \\
\hline \multirow[t]{4}{*}{ Logística } & $\begin{array}{l}\text { Gerenciamento de } \\
\text { Materiais }\end{array}$ & $\begin{array}{l}\text { Otimizar utilização de recursos, Gerar } \\
\text { reaproveitamentos internos }\end{array}$ \\
\hline & $\begin{array}{l}\text { Planejamento da } \\
\text { Produção }\end{array}$ & $\begin{array}{l}\text { Avaliação de formas de melhorar a resposta da } \\
\text { produção às necessidades da empresa e do mercado, } \\
\text { possibilitando programações em função da demanda } \\
\text { medida instantaneamente }\end{array}$ \\
\hline & $\begin{array}{l}\text { Gerenciamento da } \\
\text { Qualidade }\end{array}$ & $\begin{array}{l}\text { Medição dos niveis de qualidade e análise dos pontos } \\
\text { críticos }\end{array}$ \\
\hline & Manutenção da Planta & $\begin{array}{l}\text { Avaliação do desempenho da planta, dos pontos } \\
\text { criticos da manutenção e dos custos envolvidos }\end{array}$ \\
\hline
\end{tabular}




\begin{tabular}{|l|l|l|}
\hline Perspectiva da Inovação e do Aprendizado \\
\hline Área & Módulo de Sistema & $\begin{array}{l}\text { Inovar e Criar Opções Vantajosas, Redução do } \\
\text { Custo Final do Produto, Melhoria do Conforto, } \\
\text { Melhoria da Ergonomia, Aumento da Capacidade } \\
\text { Produtiva, Inovação nos métodos projetuais }\end{array}$ \\
\hline & Soluções da Indústria & $\begin{array}{l}\text { Análise das possibilidades disponibilizadas pelos } \\
\text { avanços do setor }\end{array}$ \\
\cline { 2 - 3 } & Atendimento ao Cliente & $\begin{array}{l}\text { Busca de interação com o consumidor e utilização de } \\
\text { suas expectativas como contribuição na melhoria do } \\
\text { produto/ serviço }\end{array}$ \\
\hline Suprimentos & $\begin{array}{l}\text { Gerenciamento de } \\
\text { Materiais }\end{array}$ & $\begin{array}{l}\text { Otimizar utilização de recursos, Gerar } \\
\text { reaproveitamentos internos }\end{array}$ \\
\cline { 2 - 3 } & $\begin{array}{l}\text { Gerenciamento da } \\
\text { Qualidade }\end{array}$ & $\begin{array}{l}\text { Medição dos niveis de qualidade e análise dos pontos } \\
\text { criticos }\end{array}$ \\
\hline
\end{tabular}

Não se tem aqui a intenção de se detalhar ou de se justificar cada uma das fontes de informação (oriundas dos sistemas corporativos), mas apenas dar uma sugestão de escopo para cada uma delas. O método utilizado na elaboração das tabelas baseia-se tão somente na percepção dentro da empresa, tendo sido vários itens, validados junto às áreas aqui citadas, porém, do ponto de vista de implementação do modelo, este material é apenas uma pequena base.

Poder-se ia ainda descer a mais um tipo de detalhamento, que seria especificar, dos sistemas listados e dos dados utilizados, quais seriam primordialmente utilizados em cada fase especifica do projeto, ou seja, quais seriam destinados ao estudo preliminar, quais seriam da fase de ante-projeto e quais entrariam na fase de detalhamento. O motivo que me leva a não fazer essa separação é o fato de as tabelas: Tabela 8, Tabela 9, Tabela 10 e Tabela 11, mostrarem as informações já de uma forma bastante subjetiva, podendo as mesmas terem graus diferentes em função da fase do projeto onde elas são utilizadas, ou seja, uma mesma informação pode ser vista durante todo o desenvolvimento do projeto, porém com enfoques diferentes. Em termos de custos, por exemplo (que é un dado mais fácil de lidar), pode-se utilizar uma visão mais macro (com filtros de informação mais genéricos) no inicio do desenvolvimento do projeto e uma visão bastante detalhada conforme 
se chega ao final do desenvolvimento, desmembrando os custos até se ter o grau de acuracidade desejado. Mas nada impede de no decorrer do processo de implantação de um recurso de disponibilização de informação utilizando o método "Balanced scorecard", sejam feitas formas seletivas de se visualizar a informação, não no sentido de se limitar a informação disponível, mas no sentido de se disponibilizar uma informação mais focada para cada momento do desenvolvimento. 


\section{Conclusão}

Não há aqui a presunção de se chegar a uma resposta definitiva ao problema de se obter subsídios ao desenvolvimento do projeto em termos de informações vindas do banco de dados corporativo.

Trata-se de um levantamento baseado em métodos, e pautado em uma experiência profissional e acadêmica, que tenta mostrar alguns direcionamentos, sempre com a visão da área de projetos e levando em conta os processos envolvidos no desenvolvimento de projetos. Teve-se o intuito de destacar a importancia da utilização de métodos de análise e de tentar posicionar a área de projetos - com relação ao grau de informações oferecido - em um patamar no mínimo equivalente àquilo que é oferecido às demais áreas estratégicas da empresa, e com certeza, com características de maior utilidade do que simplesmente oferecer um acesso livre aos bancos de dados existentes na empresa.

Essa tentativa de romper barreiras inter departamentais, através do acesso aos dados corporativos, é uma forma de se dar essa visão mais abrangente da empresa. Utilizando o método do "Balanced Scorecard", esse rompimento é facilitado, na medida em que estimula a troca de conhecimento mútuo para que seja possivel uma definição mais clara das metas. Com isso, a área de projetos fica exposta à companhia, com seu real valor estratégico, e não relegada a uma área executora, como ocorre em muitas estruturas organizacionais ainda hoje.

Não se trata de algo trivial, pois exige uma abertura das áreas da empresa que nem sempre é vista com bons olhos. Também é importante formar um time, ou uma equipe que se envolva diretamente com esse processo, buscando a sinergia das várias áreas, tratando de quebrar algumas barreiras e fazendo as ligações necessárias entre pessoas, áreas e sistemas. 
Não é fácil também a formação deste tipo de equipe: o profissional envolvido deve ter um perfil diferenciado, bastante multi disciplinar. Deve ter a habilidade de tratar com assuntos desde os mais técnicos até os mais humanistas e ter uma capacidade de síntese elevada. A utilização de consultorias, ou pessoas com a visão de fora da empresa também pode ser bastante recomendada, desde que a mesma não imponha metodologias muito rigidas, mas sim técnicas mais flexíveis que levem em consideração o ambiente específico da empresa.

Desta forma, o simples fato de se fazer a auto análise da empresa, já gera um resultado efetivo, uma vez que as pessoas envolvidas no processo ganham todo um conhecimento que pode ser estendido aos demais funcionários da empresa. Como consequiência, surgem também os questionamentos sobre pontos falhos ou pontos críticos dentro da empresa (no caso específico, dentro da área de projetos).

E finalmente, ressalto que a opção pela utilização do método "Balanced Scorecard", não exclui o conhecimento de outros métodos (como o "Análise dos Fatores Críticos do sucesso (FCSs)") ou mesmo um método composto a ser proposto. Tal conhecimento acaba agregando fundamentos ao método do "Balanced Scorecard" e até mesmo apontando eventuais falhas que podem ser abrandadas. Porém, para a abordagem deste trabalho, o método "Balanced scorecard" me parece bastante adequado, uma vez que oferece a visão das metas, sendo esta a principal colaboração, ou seja, uma forma de direcionar os esforços de qualquer especificação, respondendo a algumas questões bastante fundamentais.

A partir destas perguntas, pode-se procurar algumas respostas, baseadas sempre nas informações (tanto internas quanto externas), e, em conjunto com uma visão organizacional da empresa, de sua estrutura funcional e do conhecimento das características dos dados que pertencem à empresa (ou que constituem a empresa) passa a 
ser possível uma sinergia interna e uma otimização na utilização de tais informações.

Para um resultado mais efetivo, fatores relevantes, segundo entendo, são:

- Pessoal qualificado envolvido;

- Disposição da empresa em gerar melhorias e

- Comprometimento com o consumidor do produto da empresa.

Atendendo a estes requisitos, os demais são apenas formas de operacionalizar o processo.

Este trabalho - repetindo - não se esgota aqui. Na verdade, do ponto onde se chegou, alguns caminhos podem ser seguidos. O mais natural, e que poderia ser explorado em futuros trabalhos, seria a aplicação prática do método, utilizando-se uma situação real, ou seja, uma empresa com algum tipo de produto especifico e com um ambiente de dados específico e passivel de ser analisado.

Tendo o caso prático, tornam-se possível:

1. A validação de toda especificação feita neste trabalho;

2. detalhamento por fases do projeto;

3. desenho de meios de acesso às informações especificadas;

4. A avaliação do incremento na qualidade do projeto em função da utilização da metodologia proposta.

Há portanto um longo caminho a ser percorrido ainda, mas talvez uma das partes mais importantes do processo, que é a do autoconhecimento da empresa e de seus objetivos junto aos seus 
consumidores, e do inter-relacionamento das áreas, seja cumprido até onde este trabalho pára. 


\section{Anexo}

\subsection{Exemplo de aplicação de Engenharia Simultânea}

Este exemplo extraido de KANNAPAN; MARSHEK (?) aborda dois aspectos bastante relevantes dentro do projeto de produtos mecânicos: o primeiro é conceitual e relacionado especificamente à função do produto e o segundo diz respeito ao projeto de elementos de máquinas para que se possa conseguir a funcionalidade da mesma.

o uso da Engenharia Simultânea, de acordo com os autores, pode gerenciar várias fontes de conhecimento projetual de forma a reduzir o "time-to-market" dos produtos além de propiciar um aumento significativo da qualidade.

\subsubsection{Projeto Paramétrico de Elementos de Máquinas}

Muitos elementos de máquinas possuem parâmetros projetuais conhecidos e controláveis. Tais parâmetros podem assumir valores específicos tais que satisfaçam condições de um problema ou, por outro lado, podem variar (dentro de um intervalo) de forma a satisfazer condições individuais requeridas por uma gama de problemas. Quando os parâmetros são independentes uns dos outros, seus valores podem ser definidos a esmo, entretanto, normalmente os parâmetros são correlacionados através de princípios físicos, de geometria, de mecânica, etc.

São sugeridos dois passos a serem observados no projeto de elementos de máquinas utilizando projeto paramétrico: 
- determinar parâmetros de estrutura e de comportamento que possam variar para o elemento, derivando a seguir relacionamentos equacionais entre os vários parâmetros e

- para um dado problema específico, determinar os valores de parâmetros não conhecidos a partir dos valores de parâmetros conhecidos envolvidos em relacionamentos derivados.

Para que a metodologia seja melhor visualizada, é introduzido um gráfico de projeto que contempla os parâmetros e seus relacionamento. É exemplificado o caso de uma barra sujeita a uma carga, explicitando o relacionamento:

$\Delta=\left(\mathrm{PL}^{3}\right) /(3 \mathrm{EI})$

Que expressa a deformação causada por uma força $P$ na extremidade livre da barra que tem comprimento $I$, momento de inércia $I$ e módulo de elasticidade $E$. São separadas categorias da seguinte forma:

$\Delta$ é um parâmetro de deflexão,

E é um parâmetro de material,

L e I são parâmetros de geometria e

P é um parâmetro de carga.

Ao diagrama de projeto são adicionados novos relacionamentos:

$$
\begin{aligned}
& \sigma_{\text {máx }}=\mathrm{MC} / \mathrm{I}, \\
& \mathrm{M}=\mathrm{PL}, \\
& \mathrm{I}=\mathrm{bh}^{3} / 12, \\
& \mathrm{C}=\mathrm{h} / 2
\end{aligned}
$$


Onde b é a base da secção da barra, h é a altura da secção da

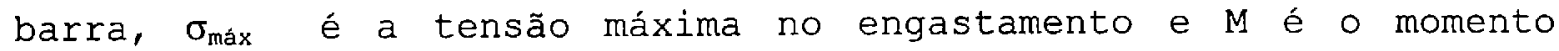
fletor aplicado à barra no engastamento.

Estes parâmetros e relacionamentos, uma vez sendo conhecidos, permitem a construção de um diagrama completo. O passo seguinte é a utilização deste diagrama na resolução de problemas. Para tanto, os autores indicam os seguintes passos:

Tabela 12: Passos para resolução do problema da barra.

assinalar os parâmetros conhecidos;

marcar setas saindo dos parâmetros assinalados e apontando para os relacionamentos nos quais eles estão envolvidos;

para os relacionamento que possuam ainda apenas uma linha não marcada como seta, marcar esta linha como uma seta saindo. Quando um relacionamento fica sem nenhuma linha que não seja uma seta, ele deve ser numerado;

os parâmetros que receberam uma seta de um relacionamento passam a ter uma linha como uma seta saindo;

Repetir o passo 3 caso haja linhas que ainda não sejam setas.

\subsubsection{Engenharia Simultânea com Negociação Utilizando Diagramas de Projeto}

Em um esquema típico de engenharia simultânea, vários projetistas interagem compartilhando informações. Os autores propõem um esquema de engenharia simultânea baseado no diagrama de projeto, onde agentes de projeto representando diferentes assuntos dentro do ciclo de vida do produto, negociam para resolver conflitos nos valores de parâmetros comuns. O método utilizado pelos autores é o estabelecido por Kalai-Smorodinsky e Nash.

o exemplo utilizado é o do projeto de uma válvula de controle de pressão como visto a seguir: 


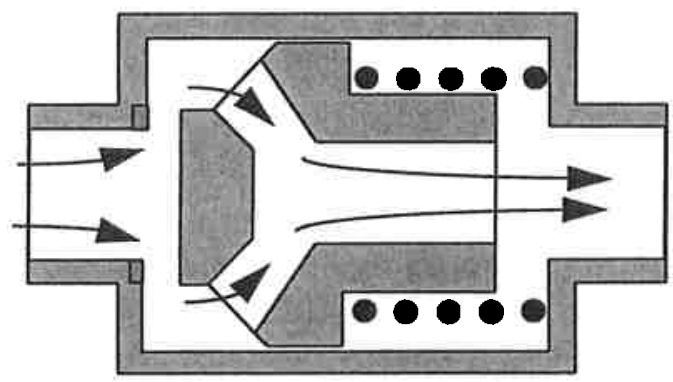

\section{Figura 20: Válvula de controle de pressão.}

Esta válvula é submetida a uma pressão (do lado esquerdo) de um fluido em um reservatório, que ao aumentar num ponto que ultrapasse a resistência à pressão da mola interna, aciona a válvula, abrindo a passagem do fluido e equilibrando novamente a pressão. Trata-se pois de um purgador de fluidos.

No projeto da válvula, os vários agentes de projeto lidam com três tipos de parâmetros:

- parâmetros dados;

- parâmetros de decisão e

- parâmetros de conflito

o primeiro tipo é aquele inerente aos materiais e às imposições externas do projeto, o segundo é o que depende exclusivamente do agente de projeto e o terceiro é compartilhado entre vários agentes, gerando necessidade de negociação.

No projeto deste pequeno elemento foram computados os parâmetros:

A área da seç̧ão transversal da tubulação

A1 resistência a corrosão permitida na casca 
A2 resistência a corrosão permitida no corpo

Acl taxa de choque permitida

C índice da mola helicoidal

$\mathrm{C}_{\mathrm{V}}$ fator de configuração da válvula

C11 intervalo entre mola e casca

C12 intervalo entre mola e corpo

Cf coeficiente de orifício

d diâmetro do perfil da mola

dh diâmetro do furo da mola

deo diâmetro do orifício equivalente

do diâmetro do orifício

$\mathrm{d}_{\mathrm{S}}$ diâmetro do selador

dL diâmetro da tubulação

D diâmetro principal da mola

Di diâmetro interno da casca da mola

Do diâmetro externo da casca da mola

Dv diâmetro externo da válvula

$\mathrm{Fe}$ força de abertura na mola

Fd força dinâmica do fluido

Ft força total sobre a mola

g gravidade

G modulo de ruptura do material da mola

$k_{S} \quad$ taxa computada da mola

kact taxa corrente da mola

K coeficiente de fluxo 


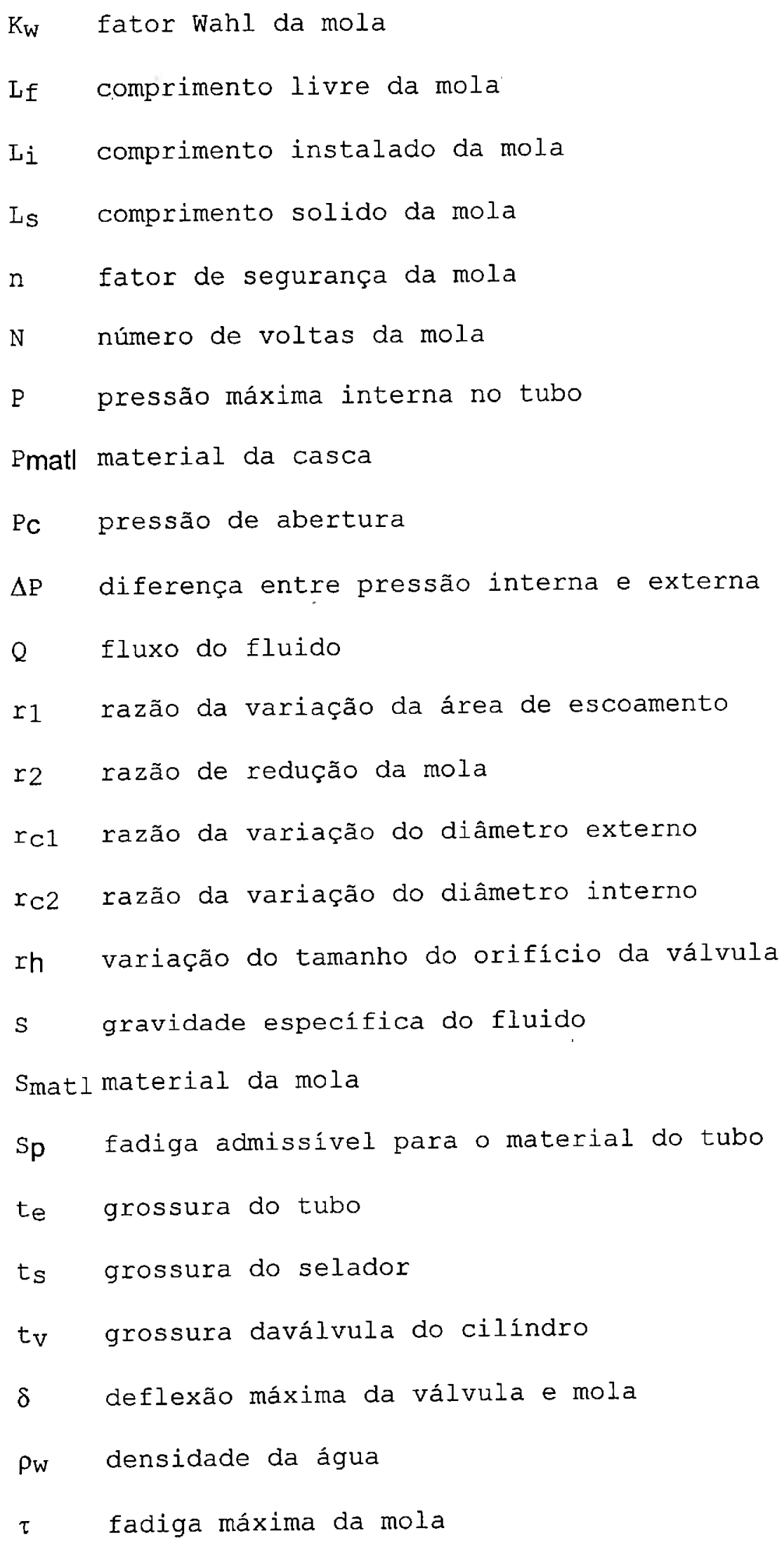


$\tau_{a l l}$ fadigạ admissível do material da mola

Para o processo de negociação são sugeridos os seguintes passos:

Determinar o conjunto de parâmetros exclusivos que afetam parâmetros de conflito;

Do conjunto determinado no passo anterior, selecionar um parâmetro de decisão por agente de projeto, que não afete nenhum outro parâmetro de conflito;

Através da negociação, computar as soluções para os parâmetros de conflito das relações do passo anterior;

Propagar as soluções de conflito aos agentes de projeto para determinar os valores dos parâmetros definidos no passo 2 .

No diagrama a seguir é visto o relacionamento dos parâmetros para - caso exposto. Utilizando Nash e Kalai-Smorodinsky para achar os pontos ótimos, chega-se à solução do projeto. 


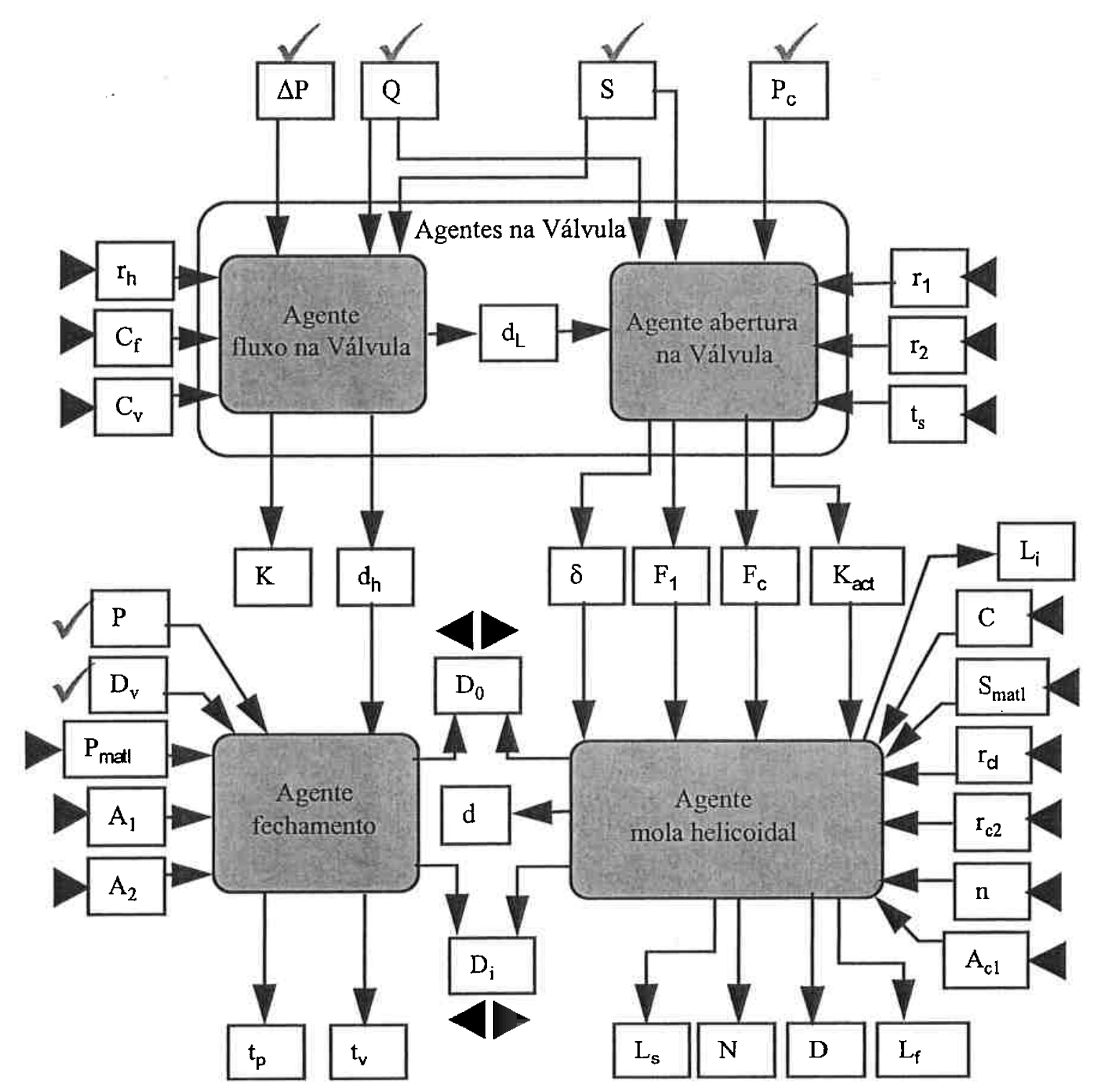

Figura 21: Relacionamento entre parâmetros para cálculo da válvula.

O método de Nash e Kalai-Smorodinsky usa funções de variação dos parâmetros e combina-as de forma a encontrar o ponto ótimo para dois ou mais parâmetros de conflito. Os autores não descrevem neste texto pormenorizadamente a forma de cálculo, mas deixa claro que existe de fato um processo de negociação. 
Por seu caráter genérico, esta metodologia pode muito bem ser aplicada em uma grande variedade de projetos mecânicos, fornecendo subsidios para, entre outras coisas, a padronização, o aumento da qualidade e a rapidez do projeto.

Além disso, no uso do $C A D$ ou $C A E$, torna-se uma ferramenta poderosa, com alto grau de aplicabilidade. 


\section{Bibliografia:}

1. ASIMOV, M. Introduction to Design, Prentice Hall, 1962

2. BADIRU, A.B. Project management in manufacturing and high technology operations, John Wiley \& Sons, 1988.

3. BARRETO, M. P. CIM: um alvo em constante movimento, Revista Automação e Indústria, São Paulo, SP, 1991

4. BHIDE, A. How entrepreneurs craft strategies that work, Harvard Business Review, Nov./Dec., 1992.

5. CHESBROUGH, H. W.; TEECE, D. J. When Is Virtual Virtuous? Harvard Business Review, fev., 1996.

6. CORRÊA, H. L.; SLACK, N. D. C. Flexibilidade estratégica na manufatura: incertezas e variabilidade de saída, Revista de Administração da USP, Vol. 29, Num 1, 1994.

7. GERBER, M. E. O mito do empreendedor, Editora Saraiva, 1990.

8. GIANESI, I. G. N.; CORRÊA, H. L. Administração Estratégica de Serviços, Editora Atlas S.A., São Paulo, 1994

9. GROOVER, M. P.; ZIMMERS Jr, E. W. CAD/CAM Computer-Aided Design and Manufacturing, Prentice-Hall, Inc., Englewood Cliffs, New Jersey, 1984 
10. GUPTA, V. R. An Introduction to Data warehousing, system Service corporation, Chicago, 1997 - (http://www.systemservice.com)

11. HENDERSON, J. C.; SIFONIS, J. G. The Value Added of strategic IS Planning: Understanding Consistency, Validity, and IS Markets, Center of Information System Research Sloam School of Management, Massachusetts Institute of Technology, $\mathrm{n}^{0}$ 145 , Nov 1986.

12. KAMINSKI, P. C. Desenvolvendo Produtos com Planejamento, Criatividade e Qualidade, Livros Técnicos e Cientificos Editora S.A., Rio de Janeiro, 2000.

13. KANNAPAN, S. M.; MARSHEK, K. M. An Approach to Parametric Machine Design and Negotiation in Concurrent Engineering

14. KAPLAN, R. S.; NORTON, D. P. Putting the Balanced Scorecard to Work, Harvard Business Review, Set./Out., 1993.

15. KAPLAN, R. S.; NORTON, D. P. The Balanced Scorecard - Mesures that drive performance, Harvard Business Review, Jan.Fev., 1992.

16. KAY, M. J. Making mass customization happen: lessons for implementation, The Planning Review Julho/Ago. 1993.

17. KOCHAN, A.; COWAN, D. Implementing CIM - Computer Integrated Manufaturing, IFS Ltd, UK, 1986. 
18. KOTLER, P. Administração de Marketing, Ed. Atlas, São Paulo, 1993.

19. LAND, G.; JARMAN, B. Breakpoint and Beyond, HarperBusiness, Chicago, 1992 .

20. LAUDON, K. C.; LAUDON, J. P. Management information systems: organization and technology, 3rd ed. Macmillan Publishing Company, New York, 1994

21. Managing Product Life Cycles: From Start to Finish, Harvard Business Paperback, 1991

22. MÄNTYLÄ M. An Introduction to Solid Modeling, Computer Science Press, Rockville, Maryland, 1988

23. MARX, R. Processo de Trabalho e Grupos Semi-Autônomos: A Evolução da Experiência Sueca de Kalmar aos Anos 90 - RAE Fundação Getúlio Vargas, abr./jun., 1992

24. MINTZBERG, H., The Fall and Rise of Strategic Planning, Harvard Business Review - Jan./Fev., 1994.

25. NEWMAN, W. M.; SPROULL, R. F. Principles of Interactive Computer Graphics, 2nd ed. McGraw-Hill Book Company, New York, 1979

26. OGLIARI, A, Sistematização da Concepção de Produtos Auxiliada por Computador com Aplicações no Domínio de Componentes de Plástico Injetados, Tese de Doutorado - Universidade Federal de Santa Catarina, Florianópolis, 1999 
27. PINE II, B. J., Mass customizing products and services, The Planning Review, Julho/Ago., 1993.

28. PORTER, M. E. Estratégia competitiva: Técnicas para análise de indústrias e da Concorrência, Ed. Campos, Rio de Janeiro, 1991.

29. PRAHALAD, C. K.; HAMEL, G. The Core Competence of the Corporation, Harvard Business Review, Maio/Junho, 1990.

30. ROBERT, M. The Strategic Heartbeat of the Business: The Driving Force - The Strategist CEO, How Visionary Executives Build Organizations, Quorum Books, New York, 1991.

31. ROWE; DICKEL; MASON; SNYDER strategic Management - A Methodological Approach, Addison-Wesley, Massachusetts, 1990.

32. RUMBAUGH, J.; BLAHA, M.; PREMERLANI, W.; EDDY, E.; LORENSEN, W. object-Oriented Modeling and Design, Prentice Hall, New Jersey, 1991 .

33. SALERNO, M. S. Mudança Organizacional e Trabalho Direto em Função de Flexibilidade e Performance da Produção Industrial, Engenharia de Produção, USP, 1994.

34. SERVA, M. O Paradigma da Complexidade e a Análise Organizacional, RAE, Fundação Getúlio Vargas, abr./jun., São Paulo, 1992 
35. SHIGLEY, J. E. Mechanical Engineering Design, 3rd ed., McGrawHill Book Company, New York, 1989.

36. SLACK, N. Vantagem Competitiva em Manufatura, Editora Atlas, São Paulo, 1993.

37. SYAN, C. S; MENON, U. Concurrent Engineering - Concepts, implementation and practice, Chapman \& Hall, London, 1994.

38. THOMPSON, J. L., Strategic management: awareness and change, Chapman \& Hall, Londres, 1990.

39. TREGOE, B. B.; ZIMMERMAN, J. W.; SMITH, R. A.; TOBIA, P. M. Vision in Action - Putting a winning Strategy to Work, Simon \& Schuster, New York, 1992.

40. TRONCHIN, V. J, Data Wahehousing - Uma Atitude Estratégica, DBMS, Mantelmedia Editora, out. Número 6, São Paulo, 1997

41. WB 100 - R/3 Business Process Overview Workshop, Apostila de treinamento da SAP do Brasil, 1999.

42. WHITTINGTON, R. What is strategy - and does it matter?, Routledge, Londres, 1993.

43. WOMMACK, J. P.; JONES, D. T.; ROOS, D. A Máquina que Mudou o Mundo, Editora Campus Ltda., 1992

44. ZEID, I. CAD/CAM THEORY AND PRACTICE, MCGRAW HILL, 1991 